Universidade de São Paulo

Faculdade de Ciências Farmacêuticas de Ribeirão Preto

\author{
SIMONE MAFALDA RODRIGUES CAMARGO
}

\title{
AVALIAÇÃO DO EFEITO DO SELÊNIO NA NEFROTOXICIDADE INDUZIDA PELA CISPLATINA EM RATOS
}

Dissertação de mestrado apresentada à Faculdade de Ciências Farmacêuticas de Ribeirão Preto para obtenção do título de mestre em Fármacos e Medicamentos, área Química e Biologia.

Orientadora: Profa. Dra. Maria de Lourdes Pires Bianchi

\section{Ribeirão Preto}

1996 
Ficha catolográfica elaborada pela Bibliotéca Central do Campus Administrativo de Ribeirâo Preto / USP

Camargo, Simone Mafalda Rodrigues

Avaliação do efeito do selênio na nefrotoxicidade induzida pela cisplatina em ratos. Ribeirão Preto, 1996.

98p.:il.; 30cm

Bibliografia:p. 70-98

Dissertação de Mestrado, apresentada à Faculdade de Ciências Farmacêuticas de Ribeirão Preto da Universide de São Paulo.

Orientadora: Bianchi, Maria de Lourdes Pires

Data de defesa:25/09/1996. 


\section{Agradecimentos}

-À Prof $\operatorname{Dr}^{\mathrm{a}}$. Maria de Lourdes Pires Bianchi pela orientação, confiança, estímulo e paciência;

-Ao Laboratório de Bromatologia e Nutrição, do Departamento de Análises Clínicas Toxicológicas e Bromatológicas da Faculdade de Ciências Farmacêuticas de Ribeirão Preto - USP, onde foi desenvolvido este trabalho;

-Ao Professor Dr. Hélio Vanucchi, do Departamento de Clínica da Faculdade de Medicina de Ribeirão Preto - USP, pelas sugestões e dedicação como assessor deste trabalho durante a sua realização;

-Aos Professores Dr. Antônio Cardoso dos Santos, do Departamento de Análises Clínicas Toxicológicas e Bromatológicas da Faculdade de Ciências Farmacêuticas de Ribeirão Preto - USP e Dra ${ }^{a}$.Terezila Machado Coimbra, do Departamento de Fisiologia da Faculdade de Medicina de Ribeirão Preto - USP, pela colaboração e sugestões durante a realização deste trabalho;

-Aos Professores Dr. Roberto da Silva Costa, do Departamento de Patologia da Faculdade de Medicina de Ribeirão Preto - USP, $\mathrm{Dr}^{\mathrm{a}}$ Regina Helena Costa Queiroz, do Departamento de Análises Clínicas Toxicológicas e 
Bromatológicas da Faculdade de Ciências Farmacêuticas de Ribeirão Preto USP e Dr.Osvaldo de Freitas, do Departamento das Ciências Farmacêuticas da Faculdade de Ciências Farmacêuticas de Ribeirão Preto - USP, pelas sugestões durante o exame de qualificação;

-Aos Professores Dr. Augusto César Cropanese Spadaro, do Departamento de Físico-Química da Faculdade de Ciência Farmacêuticas de Ribeirão Preto - USP e Dr.Nestor Schor, do Departamento de medicina da Escola Paulista de Medicina da Universidade Federal de São Paulo, pelas valiosas sugestões na correção da pró-forma da Dissertação;

-Aos funcionários do biotério, Mauro de Oliveira e Félix Alves da Silva, pelos serviços prestados com dedicação;

-Ás bibliotecárias e funcionários da Biblioteca Central do Campus Administrativo de Ribeirão Preto, pelo serviços prestados;

- À Neife Aparecida G. Santos, pela amizade e disposição em transmitir seus conhecimentos de Laboratório;

-À Coordenação e à Comissão da Pós-graduação de Fármacos e Medicamentos da Faculdade de Ciências Farmacêuticas de Ribeirão Preto USP, pela eficiência que vem realizando seus trabalhos; 
-Aos funcionários da seção da Pós-graduação desta faculdade, Elizabeth Turccato Milan e Cleber Lupachini, pela competência com que realizam suas funções;

-Ao Prof. Dr. Marco Aurélio Sicchiaroli Lavrador, do Departamento de Físico-Química da Faculdade de Ciência Farmacêuticas de Ribeirão Preto USP, pela assessoria na análise estatística dos resultados;

-À Fundação de Amparo à Pesquisa do Estado de São Paulo (FAPESP) pelo suporte financeiro concedido, viabilizando a realização deste trabalho;

- À Coordenação do Aperfeiçoamento de Pessoal de Nível Superior (CAPES), pela bolsa de estudo concedida;

-Às minhas amigas e amigos que conviveram comigo nesse período;

- $\dot{A}$ todos que direta ou indiretamente contribuiram para a realização desse trabalho. 


\section{SUMÁRIO}

\section{RESUMO}

1-INTRODUÇÃO

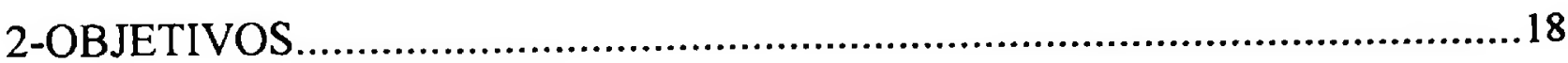

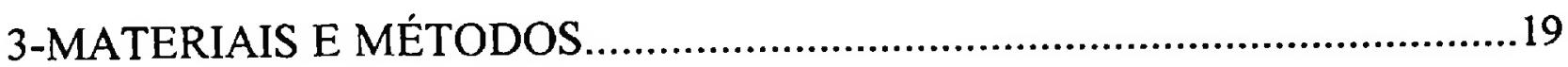

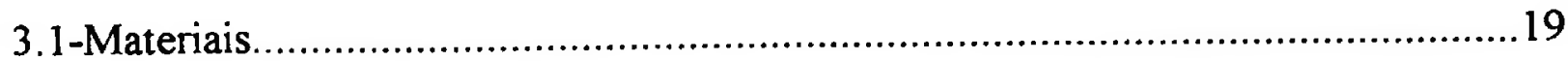

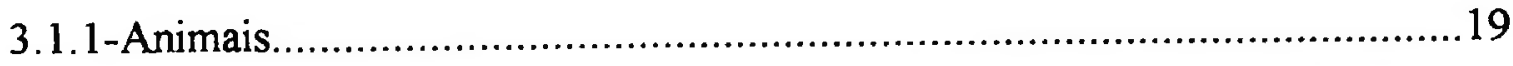

3.1.2-Ração......................................................................................... 19

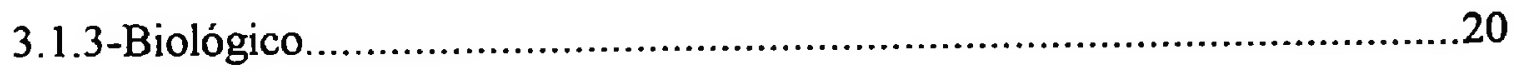

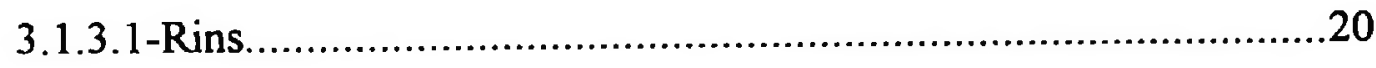

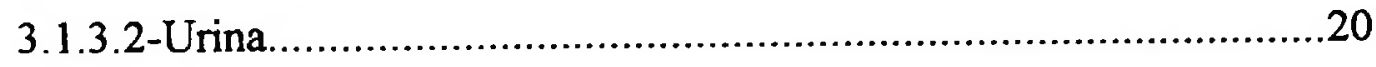

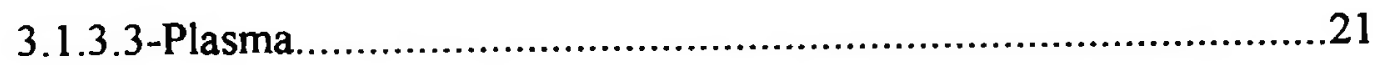

3.1.4-Drogas e reagentes...................................................................21

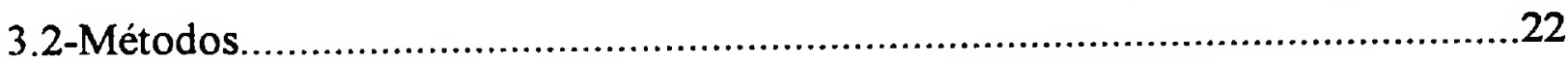

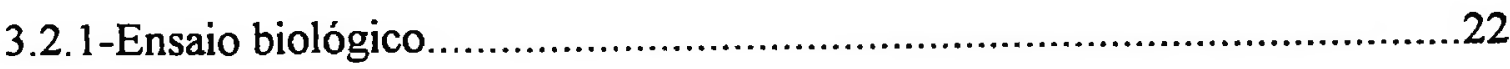

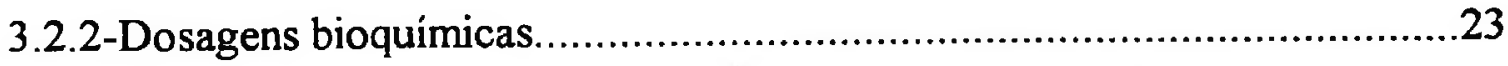

3.2.2.1-Determinação das substâncias reativas ao ácido

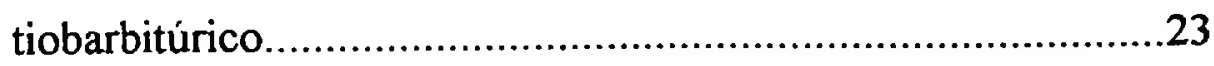

3.2.2.2-Determinação dos niveis de glutationa nos rins. 
3.2.2.3-Determinação da atividade da enzima $N$-acetil- $\beta$-Dglicosaminidase (NAG; EC3.2.1.30) Total e sua isoenzima $\mathrm{B}$ urinária. .25

3.2.2.4-Creatinina plasmática e urinária...........................................26

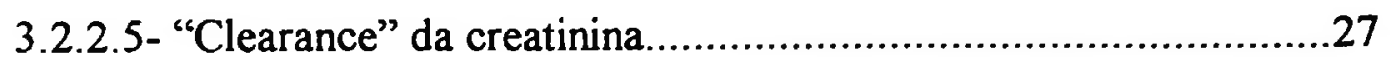

3.2.2.6- Determinação dos níveis de proteína total na urina ..................27

3.2.2.7- Determinação dos níveis teciduais de proteína.........................28

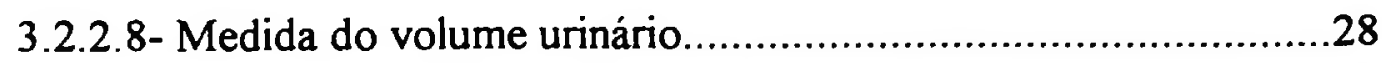

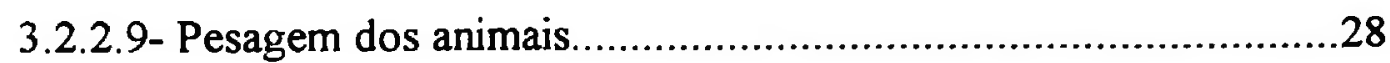

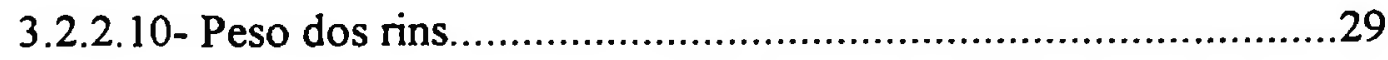

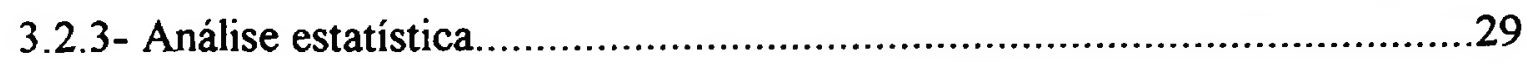

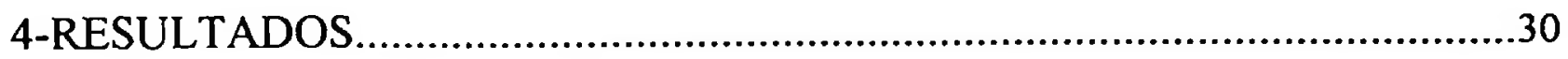

4.1- Evolução do peso dos animais........................................................................30

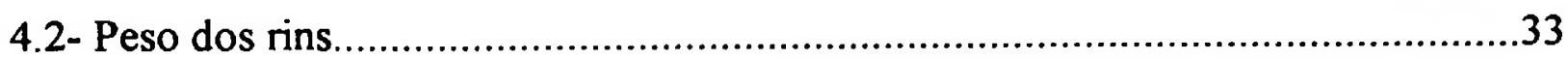

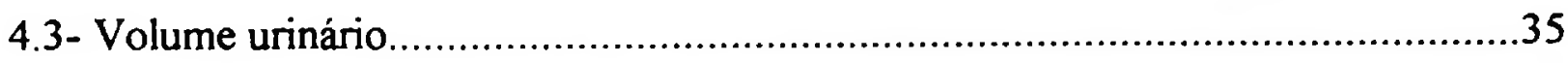

4.4- Avaliação da atividade da enzima urinária $N$-acetil- $\beta$-D- glicosaminidase

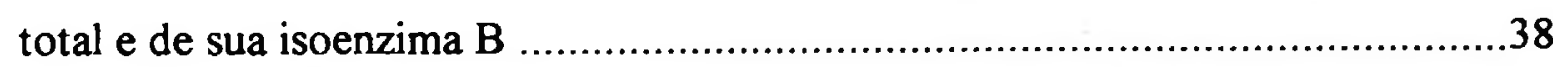

4.5- "Clearance" da creatinina e creatinina plasmática .............................................43

4.6- Niveis de proteína total na urina .................................................................

4.7- Niveis de peroxidação e glutationa nos rins....................................................50

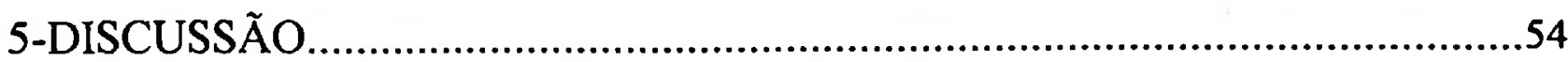

6-CONCLUSÃO

7-REFERÊNCIAS BIBLIOGRÁFICAS...................................................70

SUMMARY

APÊNDICE 


\section{RESUMO}

A cisplatina é um antineoplásico muito utilizado em clínica oncológica para o tratamento de câncer de ovário, testículo e bexiga, entre outros. Um dos fatores limitantes de seu uso é a nefrotoxicidade dose-dependente induzida pela droga. O mecanismo dessa nefrotoxicidade ainda é desconhecido, e a peroxidação lipídica parece estar envolvida neste processo. Várias substâncias têm sido utilizadas para tentar reduzir a nefrotoxicidade da cisplatina. $O$ objetivo deste trabalho foi avaliar o efeito do selênio (administrado por via oral) na nefrotoxicidade induzida pela cisplatina (administrada por via intraperitoneal) em ratos Wistar. Os animais foram divididos em 4 grupos, Controle $(n=6)$, Selênio $(n=6)$, Cisplatina $(n=6)$ e Cisplatina+Selênio $(n=6)$. Sete dias após a administração da cisplatina foram avaliados os níveis de peroxidação lipídica pelo método das substâncias reativas ao ácido tiobarbitúrico e os níveis de glutationa nos rins. Para avaliar o efeito nefrotóxico determinou-se os niveis diários da enzima $\mathrm{N}$-acetil- $\beta$-D-glucosaminidase (NAG) total e isoenzima $\mathrm{B}$, volume urinário, proteína urinária total, creatinina plasmática e "clearance" da creatinina. 
Podemos sugerir que a peroxidação lipídica parece estar envolvida no mecanismo de nefrotoxicidade da cisplatina. Os resultados de peso corporal e dos rins, creatinina e proteinúria obtidos, permitem concluir que o selênio administrado por gavagem 24 horas antes de uma dose única de cisplatina, administrada intraperitonealmente, não protegeu os ratos da nefrotoxicidade induzida pela cisplatina. Porém se avaliarmos os resultados de volume urinário e isoenzima B da NAG podemos sugerir que o selênio promoveu uma proteção parcial contra as lesões precoces induzida nos túbulos proximais pela cisplatina. 


\section{1-INTRODUÇÃO}

A cisplatina, cis-diaminodicloroplatina (II) é um complexo de platina que consiste de dois ligantes carreadores, $\mathrm{NH}_{3}$ e dois grupos abandonadores de cloro. Sua atividade biológica foi descoberta casualmente em 1965 por Rosenberg et al., estudando o efeito da corrente elétrica no crescimento da bactéria Escherichia coli. Verificaram que estas formavam longos filamentos, ou seja, que houve uma inibição da divisão celular, mas não do crescimento. Testaram várias substâncias que se sabia estar presente no meio e a única que apresentou resultados semelhantes foi o $\left(\mathrm{NH}_{4}\right)_{2} \mathrm{PtCl}_{6}$ (Pt IV) em concentrações de aproximadamente $10 \mathrm{ppm}$. Esse complexo negativamente carregado quando recebe uma fonte de luz ultravioleta forma um complexo neutro $\left(\mathrm{NH}_{3}\right)_{2} \mathrm{PtCl}_{4}$. $\mathrm{O}$ complexo negativamente carregado mostrou ser bactericida, enquanto o complexo neutro, um potente bacteriostático. Como produtos intermediários da sintese tem-se os complexos de platina II cis e trans, que também foram testados e verificaram que o isômero cis induziu a um crescimento filamentoso enquanto o trans não apresentou qualquer efeito (Rosenberg et al., 1967).

Em 1969, Rosenberg et al. avaliaram a atividade antitumoral de alguns complexos de platina em camundongos inoculados com sarcoma 180 
e leucemia L1210. Os compostos mais eficazes foram o cisdiaminotetracloroplatina (IV), cis-diaminodicloroplatina (II), cistetracloroetilenodiaminoplatina (IV) e dicloroetilenodiaminoplatina (II). Esses autores concluíram que os compostos inorgânicos de platina formavam uma nova classe de agentes antitumorais. Em 1972, Hill et al. realizaram o primeiro teste clínico com pacientes terminais, verificando uma notável regressão do tumor. Em 1974 observou-se que a cisplatina tinha um alto grau de atividade contra tumores testiculares e de ovário (Wallace \& Higby, 1974; Wiltshaw \& Carr, 1974). A cisplatina é um dos agentes quimioterápicos mais comumente utilizados para o tratamento de carcinomas de ovário, testículos, bexiga e pescoço (Rozencweig et al., 1977; Loehrer \& Einhorn, 1984; Rosenberg, 1985).

A cisplatina é mais efetiva quando administrada intraperitonealmente ou intravenosamente. As vias subcutânea $e$ intramuscular são pouco efetivas e a oral não é efetiva (Wolpert-DeFilippes, 1979). Em ratos e camundongos, após 10-15 minutos de uma injeção intraperitoneal, a cisplatina desaparece sendo captada pelo sangue e sistema linfático. Os órgãos que mais acumulam cisplatina são os rins, figado, adrenais, ossos e pele (Wolf \& Manaka, 1977).

Para exercer sua ação antineoplásica, a cisplatina necessita primeiramente entrar na célula, o que parece ocorrer por difusão passiva. Quando ela é dissolvida em solução aquosa, os íons cloreto são deslocados para permitir a formação de espécies aquosas, as quais são a forma ativa do composto. A concentração dos íons cloreto influencia a reatividade da cisplatina. Depois de uma administração intravenosa ela é relativamente 
pouco reativa no espaço extracelular onde a concentração de cloreto é de aproximadamente $100 \mathrm{mM}$ mas, quando atravessa a membrana, ela é ativada no espaço intracelular onde a concentração de cloreto cai para aproximadamente $3 \mathrm{mM}$. A cisplatina ativada é um potente eletrófilo e pode reagir com todo tipo de nucleófilo, incluindo os grupos sulfidrila de proteínas e grupos nucleófilos dos ácidos nucléicos (Lippard, 1987). Na célula, o alvo de ação da cisplatina é o DNA, com o qual faz uma ligação intracadeia com um par adjacente de guaninas impedindo assim a replicação do DNA e, por conseqüência, a divisão celular (Zelling $\&$ Kohn, 1979). Cogita-se que possa haver uma relação da apoptose no mecanismo de ação da cisplatina (Chu, 1994).

A cisplatina é principalmente excretada na forma inalterada ou de alguns metabólitos ainda não identificados durante as primeiras horas (Daley-Yates \& McBrien, 1984; Vermeulen et al., 1993). Em pacientes com câncer de mama e de ovário tratadas com cisplatina $\left(70 \mathrm{mg} / \mathrm{m}^{2}\right.$ por infusão) verificou-se uma forte e extensiva, mas reversivel ligação a proteínas plasmáticas, com uma cinética de primeira ordem e meia vida de 220 minutos, sendo que esta ligação diminui a sua citotoxicidade. $O$ "clearance" da platina total foi bifásico, com meia vida de 23 e 67 minutos e com evidências de haver uma terceira fase. Após 4 horas, aproximadamente 17\% da dose administrada foi excretada na urina e $23 \%$ nas primeiras 24 horas; a excreção renal parece ser predominantemente por filtração glomerular. A cisplatina não ligada a proteína, é rápida e bifasicamente eliminada do plasma com meia vida de 8-10 e 40-45 minutos (GormLey et al., 1979). 
Siddik et al. (1987) estudaram a farmacocinética da cisplatina e da carboplatina em ratos e camundongos. A eliminação mostrou-se bifásica num periodo de 60 minutos, com meia vida $\alpha$ de 1,5 minutos para ambas e meia vida $\beta$ de 14,5 e 10,4 minutos para a platina total e para a platina livre, respectivamente. A cisplatina reage irreversivelmente com proteínas no plasma e, após os primeiros 10 minutos, a droga livre desaparece rapidamente não sendo detectada em 60 minutos. A principal via de excreção da cisplatina é através da urina, onde $43-48 \%$ foi eliminada dentro de 4 horas. O "clearance" da cisplatina foi maior que da inulina, sugerindo um mecanismo secretor renal ativo. A excreção biliar foi de $0,4-1,2 \%$ da dose administrada em 6 horas.

Em humanos, prefere-se uma infusão lenta a administração rápida sob a forma de "bolus" devido a ligação forte a proteínas plasmáticas, que diminui sua citotoxicidade e a meia vida curta da platina livre, que é a forma ativa (GormLey et al., 1979; Daley-Yates \& McBrien, 1984; Siddik et al., 1987).

Seus efeitos tóxicos foram primeiro observados em humanos e depois estudados em modelos animais (Rosenberg, 1985). Os principais efeitos colaterais são a náusea e vômito, nefrotoxicidade, hipomagnesemia, neuropatia periférica, ototoxicidade e supressão da medula óssea. Relatos recentes do fenômeno de Raynaud, infarto do miocárdio e hipertensão sugerem que a lesão vascular é outro importante efeito colateral associado a cisplatina (Içly et al., 1993; Tuxen \& Hansen, 1994).

A nefrotoxicidade causada pela droga é, geralmente, o efeito colateral limitante de seu uso (De Conti et al., 1973; Dentino et al., 1978), 
podendo ser classificada em aguda ou crônica. Aproximadamente $25 \%$ dos pacientes que receberam uma única dose de cisplatina desenvolveram azotemia reversível (Kovach et al., 1973). Insuficiência renal irreversível, que necessitou diálise, foi observada especialmente quando utilizaram-se grandes doses ou múltiplos cursos de tratamento (Higby et al., 1973). Administração de dose única de $75 \mathrm{mg} / \mathrm{m}^{2}$ produziu nefrotoxicidade em um de cada três casos (Madias \& Harrington, 1978).

A nefrotoxicidade aguda causada pela cisplatina é caracterizada pela diminuição da função mitocondrial (Gordon \& Gattone, 1986; Gemba et al., 1987), diminuição da atividade da ATPase (Aull et al., 1979; DaleyYates \& McBrien, 1982; Nechay \& Neldon, 1984; Uozomi \& Litterest, 1985), alteração do conteúdo de cátions na célula (Phelps et al., 1987); transporte alterado de soluto (Miura et al., 1987), persistente perda de sódio, magnésio, potássio, cálcio, água; diminuição do fluxo de sangue renal; diminuição da taxa de filtração glomerular, aumento da creatinina sérica e aumento do nitrogênio uréico do sangue (Vogelzang et al., 1985; Litterest \& Weiss, 1987; Hutchison, 1988; Seguro et al., 1989; Fillastre \& RaguenezViotte, 1989; Barros et al., 1989). Estes eventos precedem alterações na estrutura renal. A importância e relação temporal desses eventos são descritos abaixo.

O DNA mitocondrial parece ser alvo vulnerável, ou seja, a cisplatina liga-se preferencialmente ao DNA mitocondrial versus o DNA genômico numa proporção de 4 a 6 vezes maior (Olivero et al., 1995). O DNA mitocondrial não esta associado a histonas (Salazar et al., 1982) e tem mecanismos de reparo menos abundantes que o do núcleo (Clayton et al., 
1974; Clayton, 1982). O DNA mitocondrial em roedores diminui para $63 \%$, 3 a 4 dias depois da exposição à cisplatina (Maniccia-Bozzo et al., 1990). Há uma diminuição de $40 \%$ no número de mitocôndrias por núcleo, um aumento de $54 \%$ na área de superfície das mitocôndrias devido ao entumecimento, uma diminuição de $35 \%$ na taxa de respiração mitocondrial e uma diminuição de $36 \%$ na proteína respiratória citocromo c-oxidase (Singh, 1986). Também foram observados uma diminuição de $35 \%$ do citocromo $\mathrm{P} 450$, diminuição da concentração de grupos sulfidrila ligados a proteínas, dos niveis de glutationa e glutationa peroxidase, aumento da peroxidação lipídica e da glutationa oxidada (Sugiyama et al., 1989; Bompart, 1989; Bompart \& Orfila, 1990).

A mitocôndria acumula maiores concentrações de platina que aquelas encontradas no núcleo ou outras organelas (Sharma \& Edwards, 1983; Siddik et al., 1986). Levi et al. (1980), em experimento com ratos, observaram após tratamento com $6 \mathrm{mg} / \mathrm{kg}$ de cisplatina, uma diminuição dos níveis de grupos sulfidrila ( $\mathrm{SH})$ e aumento na concentração de platina nos rins, principalmente nas frações mitocôndriais e citosólicas da célula. Os autores sugerem que o efeito nefrotóxico pode estar relacionado a diminuição dos grupos sulfidrila. No entanto, por análise in vitro, verificaram que o mecanismo desta diminuição não é a interação direta da cisplatina com grupos sulfidrila (SH), o que foi contestado por Ishikawa \& Ali-Osman (1993) que provaram que a cisplatina reage diretamente com a glutationa numa razão molar de 2:1 de glutationa/cisplatina.

A mitocôndria parece ser a organela alvo da cisplatina na célula, pois Vermeulen \& Baldew (1992) demonstraram que a cisplatina não 
induz peroxidação lipídica in vitro em microssomas de rim de rato em vários sistemas teste, e também não destrói os fatores dependentes de glutationa microssomal e citosólico que protegem contra a peroxidação lipídica. A lesão mitocondrial é um evento central no estágio inicial da lesão celular (Brady et al., 1990). Ela é evidenciada pela interrupção da cadeia respiratória citocrômica que ocorre 10 minutos depois da exposição à cisplatina in vitro e precede a redução da atividade da ATPase. Diminuição do consumo de oxigênio e o índice para utilização de ATP não é visto até 20 minutos após a exposição (Brady et al 1990). O impedimento da fosforilação oxidativa da mitocôndria reduz a síntese de ATP, que é o substrato das ATPases (Mandel, 1986; Soltoft, 1986; Silva, 1987). Redução da atividade da $\mathrm{Na}, \mathrm{K}$-ATPase leva a uma alteração do gradiente intracelular/extracelular de sódio, o que inibe a reabsorção normal de sódio (Brady et al 1990). Diminuição da atividade da $\mathrm{Mg}, \mathrm{Ca}$-ATPase leva a um acúmulo de cálcio mitocondrial (Dobyan et al., 1980). A maior concentração de mitocôndria renal está no terceiro segmento $\left(\mathrm{S}_{3}\right)$ ou porção reta do túbulo proximal, localizado na porção mais externa da medula, justificando ser esta a região primeiramente lesada (Tisher, 1981).

Zhang \& Lindup (1993) em estudos in vitro com mitocôndrias do cortex de rins de ratos incubados com $2 \mathrm{mM}$ de cisplatina, verificaram que houve primariamente uma depleção de glutationa (GSH) e formação de substâncias reativas ao ácido tiobarbitúrico (SRATB). Vários parâmetros foram medidos como indicadores da lesão mitocondrial e da integridade celular e demonstraram que a citotoxicidade ocorreu subseqüente a ambos, depleção de glutationa e formação de substâncias reativas ao ácido 
tiobarbitúrico (SRATB). A depleção de glutationa (GSH) induzida pela cisplatina é um evento precoce e passo determinante no estresse oxidativo da mitocôndria de cortex renal, que pode levar a lesão irreversível da célula.

Os intermediários reativos do oxigênio são espécies que podem ser formadas em várias situações fisiológicas, inclusive durante a respiração celular. De 1 a $5 \%$ do oxigênio molecular $\left(\mathrm{O}_{2}\right)$ sofre uma redução incompleta e forma o radical superóxido $\left(\mathrm{O}_{2}{ }^{\circ} \bullet\right.$, quando deveria, após uma redução tetravalente, ser reduzido a água. $\mathrm{O}$ organismo tem um sistema de defesa específico que metaboliza esta espécie reativa, o anion superóxido a peróxido de hidrogênio pela ação da enzima superóxido dismutase; esse peróxido de hidrogênio é subseqüentemente reduzido a água pelas enzimas glutationa peroxidase ou catalase. Em algumas situações em que há o aumento da produção desses intermediários ou uma diminuição do sistema de defesa, os anions superóxido e peróxido de hidrogênio podem reagir na presença de ions férrico, reação de Haber-Weiss e produzir uma espécie muito mais reativa, o radical hidroxil $\left(\mathrm{OH}^{-} \bullet\right)$ que pode abstrair hidrogênios de lipídios, proteínas, DNA e desencadear uma reação em cadeia de propagação de radicais livres. Nas membranas os ácidos graxos insaturados mudam a sua configuração e desestruturam a bicamada lipídica, podendo desencadear uma série de mudanças e levar a célula à morte (Jaeschke, 1995).

Sadzuka et al. (1992) verificaram que após o tratamento de ratos com cisplatina $(5 \mathrm{mg} / \mathrm{Kg})$ houve diminuição da atividade das enzimas superóxido dismutase dependente de cobre e zinco ( $\mathrm{Cu}-\mathrm{Zn}$ SOD), glutationa peroxidase (GSH-px), glutationa-S-transferase (GST) e catalase e que a 
peroxidação lipídica pode ser decorrente a diminuição na atividade dessas enzimas que são responsáveis pela eliminação dos intermediários reativos do oxigênio. A hipótese de que intermediários reativos do oxigênio agem como agentes patogênicos renais é reforçada por duas linhas experimentais: deteç̧ão de produtos da lesão oxidativa no tecido renal ou na urina e pela demonstração experimental do efeito protetor de inibidores metabólicos dos radicais de oxigênio (Ichikawa et al., 1994).

A nefrotoxicidade induzida pela cisplatina é iniciada pelo impedimento da reabsorção de sódio pelos túbulos proximais (Field et al., 1989). Imediatamente após a administração da cisplatina em cães e ratos, o "clearance" do lítio é significativamente aumentado enquanto a taxa de filtração glomerular e a taxa do fluxo sanguíneo permanecem inalterados. $\mathrm{O}$ aumento do "clearance" do lítio indica uma diminuição da taxa de reabsorção de sódio pelos túbulos proximais (Daugaard et al., 1986, 1988 a). Isto causa um aumento de fluido proveniente dos túbulos proximais para a porção fina descendente da alça de Henle, o que causa um aumento da reabsorção de sódio e água pelos segmentos mais distais do néfron (Shnermann, 1968, Daugaard, 1990). O aumento da reabsorção pelas porções mais distais do néfron não é suficiente para compensar a deficiência da reabsorção proximal (Daugaard et al., 1986; Daugaard, 1990). Assim, estas observações são coerentes com o aumento que ocorre na excreção de água e sódio induzida pela cisplatina. Passado esse efeito inicial, 48-72 horas após a administração da droga, em cães, observa-se uma diminuição de $77 \%$ no fluxo sanguíneo renal e $22 \%$ na taxa de filtração glomerular (Daugaard et al, 1987). Ao mesmo tempo em que há redução absoluta da taxa de 
reabsorção de sódio tanto proximal como distal (Daugaard, 1990). Em humanos, o fluxo sanguíneo renal diminui 3 horas depois da infusão de cisplatina e precede a diminuição de $23 \%$ da taxa de filtração glomerular (Meijer et al., 1983; Offerman et al., 1984; Hamilton et al., 1989). A redução no fluxo sanguíneo renal e taxa de filtração glomerular são resultantes do aumento da resistência vascular renal (Wiston \& Safirsteien, 1985; Daugaard et al., 1987) ativada pelo "feedback" túbulo-glomerular provocado pelo aumento da remessa de $\mathrm{NaCl}$ para a mácula densa nos túbulos distais (Thurau \& Boylan, 1976). A diminuição da taxa de filtração glomerular causa um menor volume de fluido na porção reta do túbulo proximal, o qual é responsável por mais da metade da reabsorção de sódio e água, causando assim uma diminuição na taxa fracional e absoluta da reabsorção de sódio e água, o que caracteriza clinicamente poliúria e hiponatriemia. A diminuição da taxa de filtração glomerular também causa aumento da creatinina sérica e do nitrogênio uréico no sangue, detectados dentre 6 ou 7 dias para humanos (Daugaard, 1990) e continuam elevados por 3 semanas (Hayes et al., 1977).

Ratos apresentam uma nefrotoxicidade dose-dependente (Litterst et al., 1985; Heidemann et al, 1990). A diminuição da taxa de filtração glomerular, caracterizada pelo aumento da creatinina sérica e o nitrogênio uréico no sangue são detectados 3 ou 4 dias após a administração de cisplatina (Singh, 1989; Daugaard, 1990), porém os níveis máximos são encontrados nos dias 5 e 7 após a administração de uma dose única (Choie et al., 1981; Bertolero \& Literest, 1982).

A cisplatina aumenta a excreção de magnésio, potássio e cálcio causando hipomagnesemia, hipocalemia e hipocalcemia. Estudos com ratos 
mostram que o aumento da excreção de magnésio pode ser secundária a diminuição da reabsorção nos túbulos proximais e distais (Schilsky \& Anderson, 1979; Mavichak et al., 1985). O aumento da excreção de potássio parece secundário a diminuição da reabsorção de sódio proximal, o que leva a um aumento da carga de sódio, potássio e água aos segmentos mais distais do néfron e permite uma secreção de potássio e sódio carga tubular dependente. A perda do potássio e cálcio renal pode ser secundária a deficiência de magnésio (Shils, 1969; Giebish \& Windhager, 1973; Fillastre \& Raguenez-Viotte, 1989). A reabsorção de sódio nos túbulos proximais diminui a troca de sódio/hidrogênio na membrana apical das células tubulares. Isto pode causar acidose das células do túbulo proximal (Osman et al., 1984; Field et al., 1989).

Apesar da descoberta de novos derivados de platina com menor efeito nefrotóxico como a carboplatina, tetraplatina, ormaplatina, CI-973, a cisplatina ainda é a mais utilizada na clínica (Perez et al., 1991; Comelison \& Reed, 1993, Leibbrant \& Wolfang, 1995), e várias condutas têm sido utilizadas para tentar diminuir sua toxicidade e permitir o uso de maiores doses (Tognela, 1990). As primeiras tentativas foram a hiperidratação (Frick et al., 1979; Al-Sarraf et al., 1982), a salina hipertônica (Litterest, 1981, Daley \& Yates, 1985) e o uso de manitol ou furosemida (Cvitkovic et al., 1977; Hayes et al., 1977; Pera et al., 1979; Pera \& Harder, 1979; Holdener et al., 1983). A hidratação intravenosa é recomendada em todos os esquemas de administração da cisplatina. No entanto, com o aumento da dose, observa-se aumento da incidência da nefrotoxicidade mesmo com a hidratação (Ozols et al., 1984). 
Outros tipos de intervenções vêm sendo avaliados em animais, tais como a procaína (Zhong et al., 1990; Zhang et al., 1996), verapamil (Haragsim \& Zima, 1992), metimazol (Vail et al., 1993), glicina (Li et al., 1994, 1995), esteres de glutationa (Babu et al, 1995), tiossulfato de sódio (Nagai et al.,1995), selênio (Naganuma et al., 1983; Berry et al., 1984; Ohkawa et al., 1988; Sugiyama et al., 1989; Baldew et al., 1989; Baldew et al., 1991) e outros.

A partir de observações que o selênio diminui a nefrotoxicidade induzida por metais pesados, como mercúrio e cádmio (Kar et al. 1960; Parizek \& Ostadalova 1967; Ganther et al. 1972; Lindh et al., 1996), alguns pesquisadores verificaram o seu efeito na nefrotoxicidade da cisplatina.

O selênio foi descoberto em 1818 por Berzelius, mas permaneceu como um elemento sem função até a década de 30 deste século, quando se verificou a sua toxicidade. O selênio presente em altas doses em forragens, provocava uma selenose crônica chamada "alkali disease" em rebanhos de algumas regiões dos Estados Unidos, caracterizada por perda de pêlos, deformação e perda dos cascos (Frank, 1934).

$\mathrm{Na}$ década de 40, Nelson et al. usando dietas com altas concentrações de selênio fornecidas a ratos, observou que o selênio foi a causa do desenvolvimento do adenoma hepático nos animais. Também Seifer et al. (1946) descreveram o aparecimento de adenomas de tireóide em ratos que receberam altas concentrações de selênio por 10 dias. Esses dados foram posteriormente analisados por Shapiro (1972), não encontrou evidências conclusivas da indução de tumor pelo selênio. Em 1975, a "Agency for Research against Câncer", depois de avaliar os dados 
biológicos com relação à ação carcinogênica do selênio em humanos, concluiu que os dados disponíveis não sugerem que o selênio seja carcinogênico para o homem (Vernie 1984).

Em 1957, Klaus Schwarz descobriu que ratos alimentados com levedura de torula e com baixas concentrações de $\alpha$-tocoferol desenvolviam uma necrose hepática fatal, o que era prevenida pela administração do selênio. O selênio até então conhecido como um elemento tóxico passou a ser considerado um elemento traço essencial.

Em 1966, Shamberger \& Rudolph observaram que o selênio utilizado topicamente inibia o desenvolvimento de tumores de pele induzidos quimicamente. Assim, verificou-se sua atividade carcinostática.

Em 1973, constatou-se que o selênio está presente numa enzima do organismo, a glutationa peroxidase (glutationa $\mathrm{H}_{2} \mathrm{O}_{2}$ oxidoredutase, E.C.1.11.1.9), em ratos (Rotruk et al., 1973). A glutationa peroxidase reduz peróxido de hidrogênio à água $\left(\mathrm{H}_{2} \mathrm{O}_{2} \rightarrow \mathrm{H}_{2} \mathrm{O}\right)$ e hidroperóxidos orgânicos à álcool ( $\mathrm{ROOH} \rightarrow \mathrm{R}-\mathrm{OH}$ ), utilizando para isso glutationa reduzida (Chaudiere, 1988; Flohe, 1989).

A fosfolipídio hidroperóxido glutationa peroxidase, outra enzima que contém selênio (Ursini et al., 1985), catalisa a redução de hidroperóxidos de fosfolipídios, colesterol e de lipoproteínas (Maiorino et al., 1991).

A iodotironina 5'deiodinase tipo I é outra enzima que contém selênio (Berry et al., 1991), ela é uma das formas mais conhecidas no metabolismo do hormônio da tireóide, triiodotiroxina (T3). Ela catalisa a 
reação que transforma tiroxina (T4) à triiodotiroxina (T3) (Gross \& PittRivers, 1952; Leonard \& Visser, 1986).

A selenoproteina $\mathrm{P}$, uma glicoproteína plasmática, (Hill et al., 1991), a selenoproteína W, uma proteína do músculo de rato (Vendeland et al. 1992) e uma proteína epididimal de camundongos (Ghyselinck et al., 1993) também contém selênio, mas ainda não têm suas funções bem definidas.

O resíduo de selênio presente em todas as selenoenzimas, tanto em mamíferos como em bactérias, é a selenocisteína. Esta é geneticamente codificada por um códon universal UGA durante a tradução a partir do seleneto de hidrogênio e serina (Mullenbach et al., 1988). O selênio (selenato, selenito, selenometionina e selenocisteína) parece ser metabolizado a partir de tióis e glutationa por diversos tipos de células. Primeiramente o composto de selênio é transformado em selenito, depois disso ele começa a ser metabolizado a custas de tióis em selenotrissulfeto (RSSeSR), depois a persulfeto de selênio (RSSeH), o qual é reduzido a seleneto de hidrogênio $\left(\mathrm{H}_{2} \mathrm{Se}\right)$; este é incorporado ao aminoácido serina e metabolizado até selenocisteína (Painter, 1941; Ganther, 1968; Esaki et al., 1981; Seko et al., 1989).

O papel do selênio é semelhante em animais e em seres humanos quando se observam os sinais e sintomas nas selenoses $\mathrm{e}$ deficiências, bem como na semelhança de funções de duas selenoenzimas (Vernie, 1984; Vendeland et al., 1992; Baliga et al.,1992; Vadhanavikit \& Ganther, 1993; Girelli et al., 1993; Spallholz, 1994; Christensen et al., 1995; Olivieri etal., 1995). Uma ingestão deficiente de selênio causa diminuição da 
atividade das selenoenzimas glutationa peroxidase e iodotironina 5'deiodinase (Vendeland et al., 1992; Vadhanavikit \& Ganther, 1993), assim como do estado de equilíbrio do RNA mensageiro para essas enzimas (Christensen et al., 1995). Em humanos também se observa uma diminuição da atividade dessas enzimas em situações de baixa ingestão de selênio (Girelli et al., 1993; Olivieri et al., 1995).

Humanos com insuficiência renal crônica apresentam baixas concentrações de selênio no sangue (independente do uso de diálise) acompanhado pela redução da atividade da glutationa peroxidase em plaquetas (Girelli et al., 1993). Ratos deficientes em selênio, submetidos à lesões glomerulares experimentais, tiveram um quadro mais drástico do que ratos suplementados. Os autores sugeriram ser devido a uma diminuição da atividade da glutationa peroxidase, que protege o organismo da lesão por estresse oxidativo (Baliga et al., 1992).

A utilização do selênio para diminuir o efeito nefrotóxico da cisplatina foi estudada por vários autores. Naganuma et al. em 1983, verificaram que camundongos que receberam selenito de sódio por via subcutânea por 10 dias, após uma dose única de cisplatina, tiveram uma menor mortalidade e redução do efeito nefrotóxico, mas sem diminuir a atividade citostática da cisplatina. Ohkawa et al. (1988) confirmaram o fato do selênio não diminuir o efeito citostático da cisplatina e ainda verificaram que o selênio aumentou em $50 \%$ a dose letal da cisplatina em camundongos, possibilitando o uso de maiores doses.

Sugiyama et al. (1989), num estudo realizado em ratos tratados com cisplatina, cisplatina mais selênio e o grupo controle (não tratado), 
mediu em cada um desses grupos a função respiratória mitocondrial, a atividade enzimática na cadeia respiratória mitocondrial, a glutationa peroxidase, a creatinina plasmática e o nitrogênio uréico. Verificou que no grupo tratado com cisplatina, houve uma diminuição na função respiratória mitocondrial, na atividade enzimática da cadeia respiratória e na glutationa peroxidase, e aumento na creatinina plasmática e nitrogênio uréico quando comparados com o grupo controle. Esses efeitos foram diminuidos quando administrou-se selênio por via intraperitonial num período de 5 dias, que evitou a inibição da glutationa peroxidase. Sendo esta uma enzima "scavenger" de radicais livres e dependente de selênio, acredita-se que esta toxicidade possa ser atribuida à lesão mediada por radicais livres e que o selênio possa ser utilizado junto a altas doses de cisplatina para diminuir a sua nefrotoxicidade.

Resultados semelhantes foram obtidos por Baldew et al. (1989), ao tratar ratos e camundongos com selenito de sódio uma hora antes da administração da cisplatina. Houve uma diminuição da nefrotoxicidade sem diminuir a capacidade antitumoral da droga. Não ocorreu efeito protetor com o tratamento de selenito de sódio uma hora depois da administração da cisplatina,

O mecanismo de interação entre a cisplatina e o selênio ainda é desconhecido. Sugiyama et al. (1989) demonstraram que o selênio impediu a diminuição da atividade da glutationa peroxidase e sugerem que esse possa ser o mecanismo da proteção. Baldew et al. (1991) sugerem que possa ser por interação da cisplatina com um metabólito do selênio, o metilselenol, 
impedindo assim que ela se ligue a grupos sulfidrila de proteinas nos rins e assim diminuindo o efeito nefrotóxico (Baldew et al., 1991).

O selênio (selenito de sódio) não modificou a farmacocinética da cisplatina em ratos quando administrados juntos e também não modificou a distribuição da cisplatina, assim como a cisplatina não influenciou na farmacocinética e distribuição do selênio (Vermeulen et al., 1993).

Visto que a via de administração mais comum do selênio em humanos é a via oral, propusemo-nos a estudar o efeito do selênio por esta via, avaliando seu efeito sobre a nefrotoxicidade induzida pela cisplatina em ratos. 


\section{2-OBJETIVOS}

2.1 - Objetivo geral

Avaliar o efeito do selênio via oral na nefrotoxicidade induzida pela cisplatina em ratos.

2.2 - Objetivos específicos

Avaliar a nefrotoxicidade induzida pela cisplatina e o efeito do selênio através do (a):

- evolução do peso corporal dos animais

-relação do peso do rim/peso do rato

•volume urinário

-nível de atividade da enzima urinária $\mathrm{N}$-acetil- $\beta$ -

D-glicosaminidase total e sua isoenzima B

- "clearance" da creatinina

-excreção de proteína total na urina

Avaliar o nível de peroxidação lipídica renal induzida pela cisplatina e o efeito do selênio através da determinação do (a):

-nível de substâncias reativas ao ácido tiobarbitúrico (SRATB) nos rins

- nível de de glutationa (GSH) nos rins 


\section{3 - MATERIAIS E MÉTODOS}

\section{1 - Materiais}

\subsection{1 - Animais}

Foram utilizados 24 ratos machos adultos (Rattus norvergicus, var. albinos, Rodentia, mammalia), linhagem Wistar, com peso de $250,64 \pm 2,75 \mathrm{~g}(x \pm \mathrm{DP})$, provenientes do Biotério Central do Campus de Ribeirão Preto da Universidade de São Paulo.

\subsection{2 - Ração}

A ração utilizada durante todo o experimento foi a ração comercial oferecida pelo Biotério Central (com formulação CIZIP-USP) proveniente do Campus de Pirassununga da Universidade de São Paulo. Esta ração tem uma concentração final de selênio de $0,136 \mathrm{mg}$ por quilo de ração provenientes tantos das fontes vegetal e animal, bem como do enriquecimento. O AIN-93 (Reeves et al., 1993) recomenda $0,15 \mathrm{mg}$ de selênio/ $\mathrm{Kg}$, de ração. Os componentes, a composição centesimal e o enriquecimento da ração são mostrados em apêndice nas tabelas 9, 10 e 11 . 


\subsection{3 - Biológico}

3.1.3.1 - Rins

Os animais foram sacrificados por decaptação cervical, os rins foram retirados, eliminou-se o excesso de líquidos com papel absorvente e foram pesados. Os rins foram utilizados para preparar o homogeinizado a $10 \%$ em solução de cloreto de potássio $1,15 \%$ gelada, onde foram avaliados os niveis de peroxidação lipídica por determinação das substâncias de reativas ao ácido tiobarbitúrico (SRATB) dentre elas, o malondialdeído (MDA). Esse mesmo homogeinizado foi utilizado para a determinação dos níveis de glutationa (GSH) e proteína.

\subsubsection{2 - Urina}

A urina de 24 horas foi coletada utilizando-se gaiolas metabólicas que permitem a separação da urina e das fezes. Durante a coleta a urina foi mantida a temperatura de aproximadamente $4^{\circ} \mathrm{C}$ com banho de gelo. Uma alíquota da amostra foi utilizada para a determinação da atividade enzimática total $e$ isoenzima $B$ da N-acetil-B-Dglicosaminidase (NAG; EC 3.2.1.30) imediatamente após a coleta; a outra fração foi armazenada em geladeira para determinação dos níveis da creatinina e proteína total. 
3.1.3.3 - Plasma

Após o sacrificio dos animais, coletou-se o sangue em tubo heparinizado com o auxílio de funil. Logo em seguida o sangue foi centrifugado, o plasma separado e armazenado em geladeira por não mais que uma semana para subseqüente determinação dos níveis da creatinina plasmática.

3.1.4 - Drogas e reagentes

Todos os reagentes utilizados para análise foram de grau analítico. A cisplatina utilizada foi a apresentação comercial PLATISTINE $^{\circledR}$ gentilmente cedida pela Pharmacia Indústria e Comércio LTDA. 
3.2 - Métodos

\subsection{1 - Ensaio biológico}

O experimento foi realizado no biotério das Faculdades de Ciências Farmacêuticas e Odontologia de Ribeirão Preto da USP.

Os animais foram mantidos em gaiolas metabólicas individuais de aço inoxidável durante todo o experimento, sob condições ambientais controladas: temperatura de $24^{\circ} \mathrm{C}$ e ciclo alternado de claro/ escuro de 12 horas. Ração e água deionizada foram oferecidas ad libitum.

Após um período de adaptação de dois dias, iniciou-se a coleta de urina de 24 horas. Esse primeiro dia de coleta antes de qualquer tratamento foi chamado dia -1 . O tratamento recebido nos próximos dias (dia 0 e dia 1 ) diferenciou os grupos:

- GRUPO 1 - controle: os animais receberam água deionizada por gavagem no dia zero e após 24 horas (dia 1) uma injeção intraperitoneal do diluente da cisplatina.

- GRUPO 2 - selênio: os animais receberam selenito de sódio $2 \mathrm{mg}$ de selênio por quilo de peso em água deionizada (Baldew et al. 1989) por gavagem no dia zero e após 24horas (dia 1) uma injeção intraperitoneal do diluente da cisplatina.

- GRUPO 3 - cisplatina: os animais receberam água deionizada por gavagem no dia zero e após 24horas (dia 1) uma 
injeção intraperitoneal de cisplatina $5 \mathrm{mg} / \mathrm{Kg}$ de peso(Mason \& Edwards 1985a, b).

- GRUPO 4 - cisplatina + selenio: os animais receberam selenito de sódio ( $2 \mathrm{mg}$ de selênio por quilo de peso em água deionizada) por gavagem no dia zero e após 24 horas (dia 1) uma injeção intraperitoneal de cisplatina $5 \mathrm{mg} / \mathrm{Kg}$ de peso.

A coleta de urina foi mantida durante o tratamento e até o 7o dia. No final do 7o dia os animais foram sacrificados e coletouse sangue e ríns. Os animais foram pesados no início do experimento, nos dias de administração das drogas (ou diluente) e nos dias 3,5 e 7 .

\subsection{2 - Dosagens bioquímicas}

3.2.2.1-Determinação das substâncias reativas ao ácido tiobarbitúrico (SRATB)

O método para a avaliação da peroxidação lipídica por determinação das substâncias reativas ao ácido tiobarbitúrico (SRATB) dentre elas, o malondialdeído (MDA) foi o preconizado por Uchiyama \& Mihara (1978):

Os rins e o figado foram cortados em pedaços pequenos e pesou-se cuidadosamente $0,3 \mathrm{~g}$ ao qual foi adicionado $3,0 \mathrm{~mL}$ de solução de $\mathrm{KCl} 1,15 \%$ gelada, homogeneizados, obtendo-se assim um homogeinizado a $10 \%$. Pipetou-se $0,5 \mathrm{~mL}$ desse homogeinizado e adicionou-se $3,0 \mathrm{~mL}$ de solução de ácido 
fosfórico $1 \%$ e 1,0mL de solução de ácido tiobarbitúrico (TBA) $0,6 \%$ que reage com as SRATB e com o MDA em especial, numa proporção de duas moléculas de TBA para cada MDA, o complexo apresenta uma cor rosa estável. A mistura foi aquecida por 45 minutos em banho de água fervente, resfriado em banho de gelo. Ao fim desse tempo adicionou-se à amostra fria $4,0 \mathrm{~mL}$ de $\mathrm{n}$-butanol, que foi misturada vigorosamente e centrifugada, em centrifuga Fanem-Exelsa 2 à 3000 rotações por minuto. Utilizou-se como padrão uma solução de 1,1',3,3'tetrametoxipropano nas concentrações de 5,125;10,25 e 20,5nmol por mL. A absorvância da fase orgânica foi medida em 520 e $535 \mathrm{~nm}$ em espectrofotômetro modelo Micronal-digital B342II. A diferença é o valor de MDA. Os resultados foram expressos em nmol de MDA/g de tecido úmido.

3.2.2.2 - Determinação dos níveis de glutationa (GSH) nos rins

Os níveis de glutationa dos rins dos ratos foi determinado pelo método de Sedlak \& Lindsay (1968) no mesmo homogeinizado (a $10 \%$ em $\mathrm{KCl}$ ) preparado para a determinação das substâncias reativas ao ácido tiobarbitúrico. Uma alíquota de $300 \mu \mathrm{L}$ foi diluida em água para $1,0 \mathrm{~mL}$. Fez-se a desproteinização pela adição de $100 \mu \mathrm{L}$ de uma solução de ácido tricloroacético $(1 \mathrm{mg} / \mathrm{mL})$, centrifugou-se e o sobrenadante foi utilizado para o teste. Em um tubo com 2,0mL de tampão tris $400 \mathrm{mmol}-\mathrm{EDTA} 20 \mathrm{mmol}-\mathrm{HCl} \mathrm{pH} 8,9$ colocou-se $500 \mu \mathrm{L}$ do 
sobrenadante e $100 \mu \mathrm{L}$ de 5,5'-ditiobis-(ácido 2-nitrobenzoico (DTNB), que é reduzido pelos grupos $\mathrm{SH}$ e forma $1 \mathrm{~mol}$ de 2nitro-5-ácido mercaptobenzóico por mol de SH. Este tem uma cor amarela intensa e pode ser utilizado para medir grupos $\mathrm{SH}$. Usou-se a L-cisteina como padrão e as determinações foram realizadas em espectrofotômetro modelo Micronal-digital B342II em 650nm. Os resultados foram expressos em nmol por mg de proteína.

3.2.2.3 - Determinação da atividade da enzima N-acetil- $B-D-$ glicosaminidase (NAG; EC 3.2.1.30) total e isoenzima B urinária.

A atividade enzimática foi determinada pelo método de Horak et al. (1981) modificado. As amostras de urina de 24 horas foram utilizadas para a determinação da NAG total e B, após filtração em Sephadex G-25 (coluna de $12 \mathrm{~cm}$ de comprimento por $0,7 \mathrm{~cm}$ de diâmetro, contendo aproximadamente 4,6 $\mathrm{mL}$ de Sephadex suspenso em $\mathrm{NaCl} \mathrm{0,15}$ $\mathrm{mol} / \mathrm{L}$ ) para separar a NAG de inibidores presentes na urina. Aplicou-se na coluna duas alíquotas de $0,5 \mathrm{~mL}$ da amostra: uma de urina diluida $50 \%$ em solução de $\mathrm{NaCl} 0,15 \mathrm{~mol} / \mathrm{L}$, e outra de $1,0 \mathrm{~mL}$ que foi aquecida à $60^{\circ} \mathrm{C}$ por 10 minutos. Eluiu e lavou com $0,5 \mathrm{~mL}$ de solução de $\mathrm{NaCl} 0,15 \mathrm{~mol} / \mathrm{L}$, em seguida eluiu novamente com 2,0mL dessa mesma solução de $\mathrm{NaCl}$. Este eluato continha a NAG livre de inibidores e foi utilizado na 
mistura reacional. Em ambas as frações, adicionou-se $0,5 \mathrm{~mL}$ do tampão citrato $0,1 \mathrm{~mol} / \mathrm{L}, \mathrm{pH} \quad 4,4$ contendo o substrato, $10 \mathrm{mmol} / \mathrm{L}$ de $\mathrm{p}$-nitrofenol-N-acetil- $\beta$-D-glicosaminide e incubou-se a mistura à $37 \circ \mathrm{C}$ por 30 minutos. A reação foi interrompida pela adição de $0,5 \mathrm{~mL}$ de tampão glicina $0,75 \mathrm{~mol} / \mathrm{L}, \mathrm{pH} \mathrm{10,25}$. A atividade da $\mathrm{NAG}$ é proporcional a absorvância do íon p-nitrofenolato liberado na reação, depois da correção da absorvância com o branco da urina. O produto da reação foi medido a $405 \mathrm{~nm}$ em espectrofotômetro modelo Micronal-digital B342II e os resultados foram expressos em $\mathrm{U} / \mathrm{g}$ de creatinina.

3.2.2.4 - Creatinina plasmática e urinária

A creatinina plasmática e urinária foram determinadas por método colorimétrico usando os reagentes de Lloyd (Henry et al., 1974), compostos basicamente de um tampão alcalino, reagente de cor a base de picrato e um acidificante. A leitura foi realizada a $510 \mathrm{~nm}$ em espectrofotômetro modelo Micronal-digital B342II. Os resultados foram apresentados em $\mathrm{mg}$ de creatinina a cada $100 \mathrm{~mL}$ de plasma. 


\subsubsection{5 - "clearance" da creatinina}

$O$ "clearance" da creatinina foi calculado a partir dos dados da creatinina urinária, creatinina plasmática, volume da urina e peso dos ratos pela fórmula abaixo:

$$
\begin{aligned}
& C l c=\frac{C u}{C p} \times \frac{V u}{t} \times \frac{100}{P} \text {, onde: } \\
& \mathrm{Cu}=\text { creatinina urinária } \\
& \mathrm{Cp}=\text { creatinina plamática } \\
& \mathrm{Vu}=\text { volume de urina } \\
& \mathrm{t}=\text { tempo de coleta da urina } \\
& \mathrm{P}=\text { peso do rato } \\
& \mathrm{O} \text { resultado foi expressos } \mathrm{em} \mathrm{mg} / \mathrm{min} / 100 \mathrm{~g} \mathrm{de}
\end{aligned}
$$

animal.

3.2.2.6 - Determinação dos niveis de proteína total na urina Os níveis de proteína total na urina foram determinados pelo método de Bradford (1976). O ensaio foi realizado em triplicata. Uma amostra de $50 \mu \mathrm{L}$ foi adicionada a $5 \mathrm{~mL}$ de reagente de "Coomassie Brilhante Bleu G-250", agitouse e após 2 minutos leu-se em espectrofotômetro modelo Micronal-digital B342II em 595nm. Usou-se como padrão uma solução de albumina a 0,$5 ; 0,25$ e $0,125 \mathrm{mg}$ por $\mathrm{mL}$. Os resultados foram apresentados em $\mathrm{mg} / \mathrm{g}$ de creatinina. 
3.2.2.7 - Determinação dos níveis teciduais de proteína

Os níveis de proteína nos rins foram determinados para poder expressar os resultados de glutationa. Para tanto utilizou-se o método de Hartree (1972) em que $50 \mu \mathrm{L}$ do homogeinizado a $10 \% \mathrm{em} \mathrm{KCl}$ foi diluido em $5 \mathrm{~mL}$ de água e $200 \mu \mathrm{L}$ desse homogeinizado foi colocado em um tubo e diluido para $1 \mathrm{~mL}$ para se efetuar a determinação.

\subsubsection{8 - Medida do volume urinário}

A urina foi coletada em provetas de vidro graduadas, o que era possível com o auxílio das gaiolas metabólicas, que permitem a separação das fezes e dos restos de ração. Na extremidade distal do funil colocou-se papel de filtro para evitar a presença de resíduos na urina. Todos os dias do experimento, na mesma hora (8:00 horas) a urina era removida e medida. $O$ funil da gaiola era trocado a cada 24 horas de coleta.

3.2.2.9 - Pesagem dos animais

Os animais foram pesados no início do experimento, no dia da administração do selênio (dia 0) e da cisplatina (dia 1) para ajustar a dose, e também nos dias 3,5 e 7. A pesagem dos animais foi realizada em balança Micronal B 600 . 
3.2.2.10 - Peso dos rins

Imediatamente após o sacrificio dos animais, os rins foram pesados numa balança Micronal B 600 sobre papel alumínio, no qual era embalado para ser colocado no gelo.

\subsection{3 - Análise estatística}

Os dados foram analisados preliminarmente através de ANOVA, num esquema fatorial $2 \times 2$, utilizando-se nível de significância de $5 \%$, com desdobramento para interação. Os casos que apresentaram diferenças significativas, foram analisados 2 a 2 , utilizando-se o teste de Tuckey (Snedocor \& Cochran, 1963; John, 1971). 


\section{4 - RESULTADOS}

4.1 - Evolução do peso dos animais

A evolução do peso dos animais durante o experimento é mostrada na Tabela 1 e Figura 1. Os resultados individuais são mostrados em apêndice nas tabelas $12,13,14$ e 15 .

Os animais do Grupo Controle apresentaram um aumento de peso durante todo o experimento. Os animais do Grupo Selênio e Cisplatina+Selênio apresentaram uma perda de peso significativa no dia 1 após a administração de selênio. A seguir os ratos do Grupo Selênio se recuperaram e apresentaram aumento de peso até o final do experimento. Nos ratos do Grupo Cisplatina e Grupo Cisplatina + Selênio observou-se perda significativa $(\mathrm{p}<0,05)$ de peso a partir do dia 3 que se manteve até o final do experimento. Não houve diferença significativa entre os Grupos Cisplatina e Cisplatina+Selênio. 


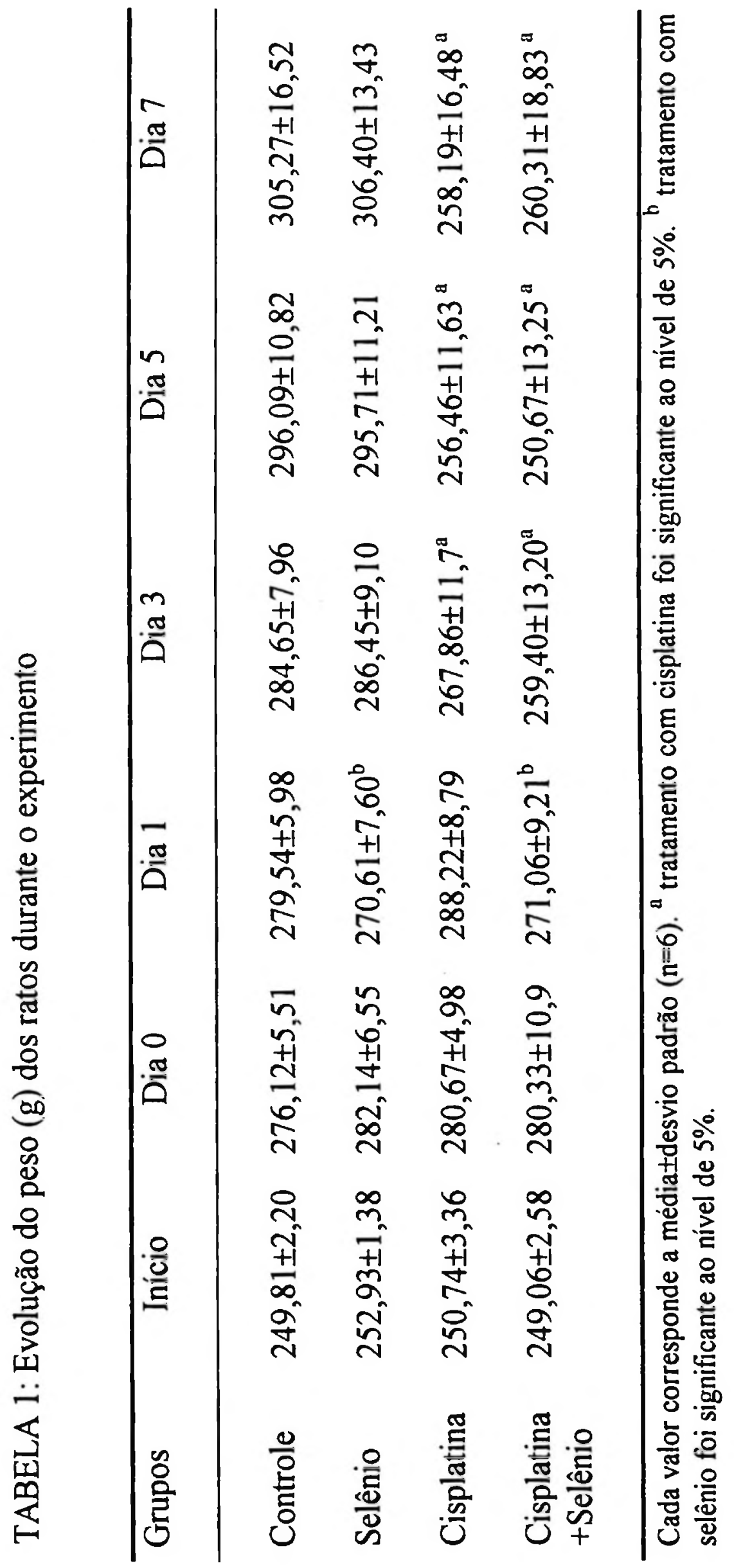




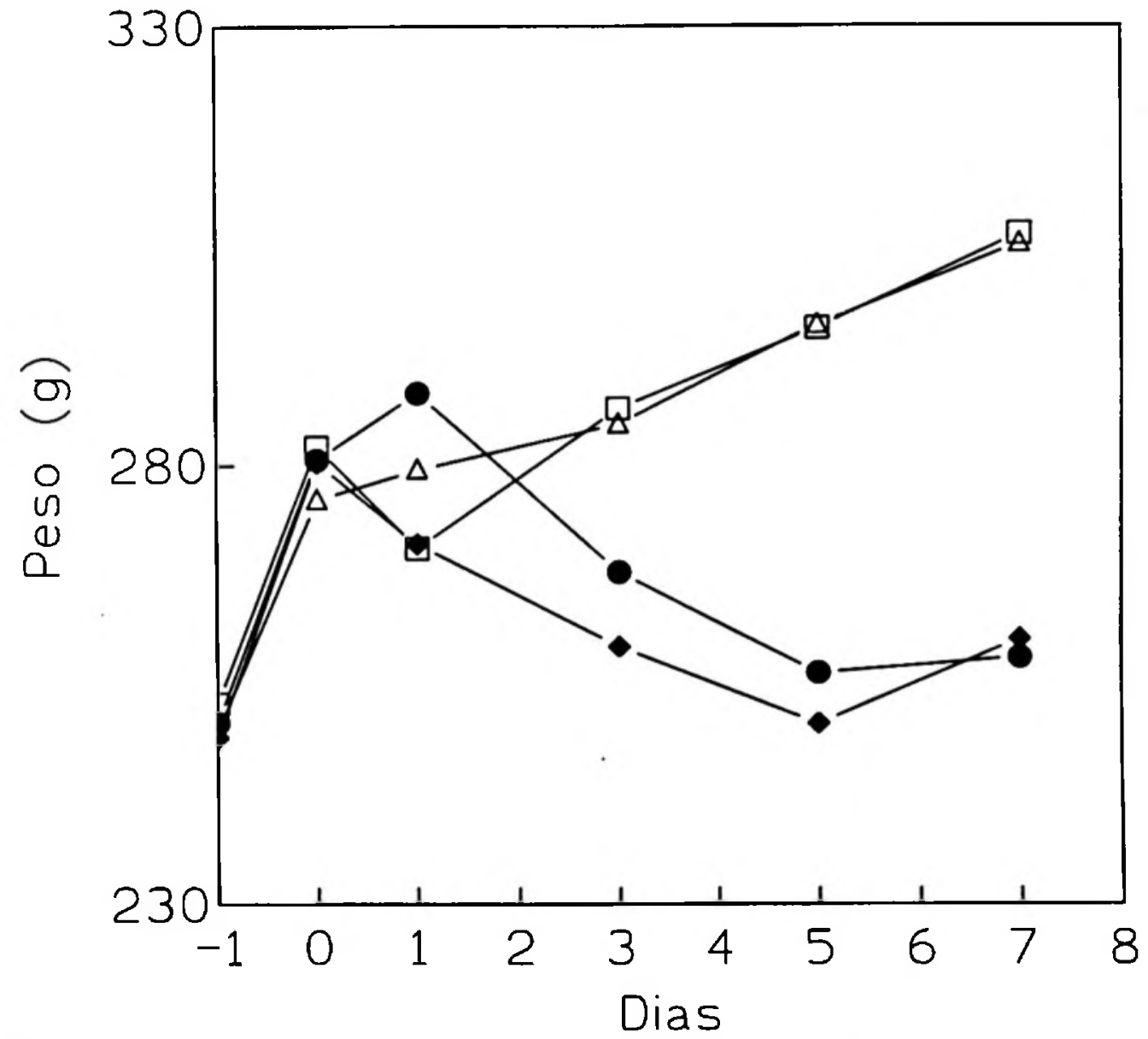

Figura 1 : Evolução do peso (g) dos ratos durante o experimento. Efeito do selênio, cisplatina e cisplatinatselênio no peso dos ratos durante todo o experimento. Os ratos foram pesados no início do experimento, no dia da administração do selênio (dia 0), no dia da administração da cisplatina (dia 1) e também nos dias 3,5 e 7 . ( $\Delta$ ) Grupo Controle, ( $\square$ ) Grupo selênio, ( $(\bullet)$ Grupo cisplatina e $(\bullet)$ Grupo Cisplatina+selênio. Cada valor corresponde a média $(n=6)$. 
4.2- Peso dos rins

O peso dos rins verificado imediatamente após o sacrificio dos animais e a relação com peso corpóreo podem ser vistos na Tabela 2 . Os resultados individuais são mostrados em apêndice na tabela 16 e 17.

Observamos um aumento significativo $(p<0,05)$ do peso dos rins, bem como do peso relativo dos rins, ou seja, a relação peso do rim/ peso do rato expressa em porcentagem, nos animais dos Grupos Cisplatina e Cisplatina+Selênio. 


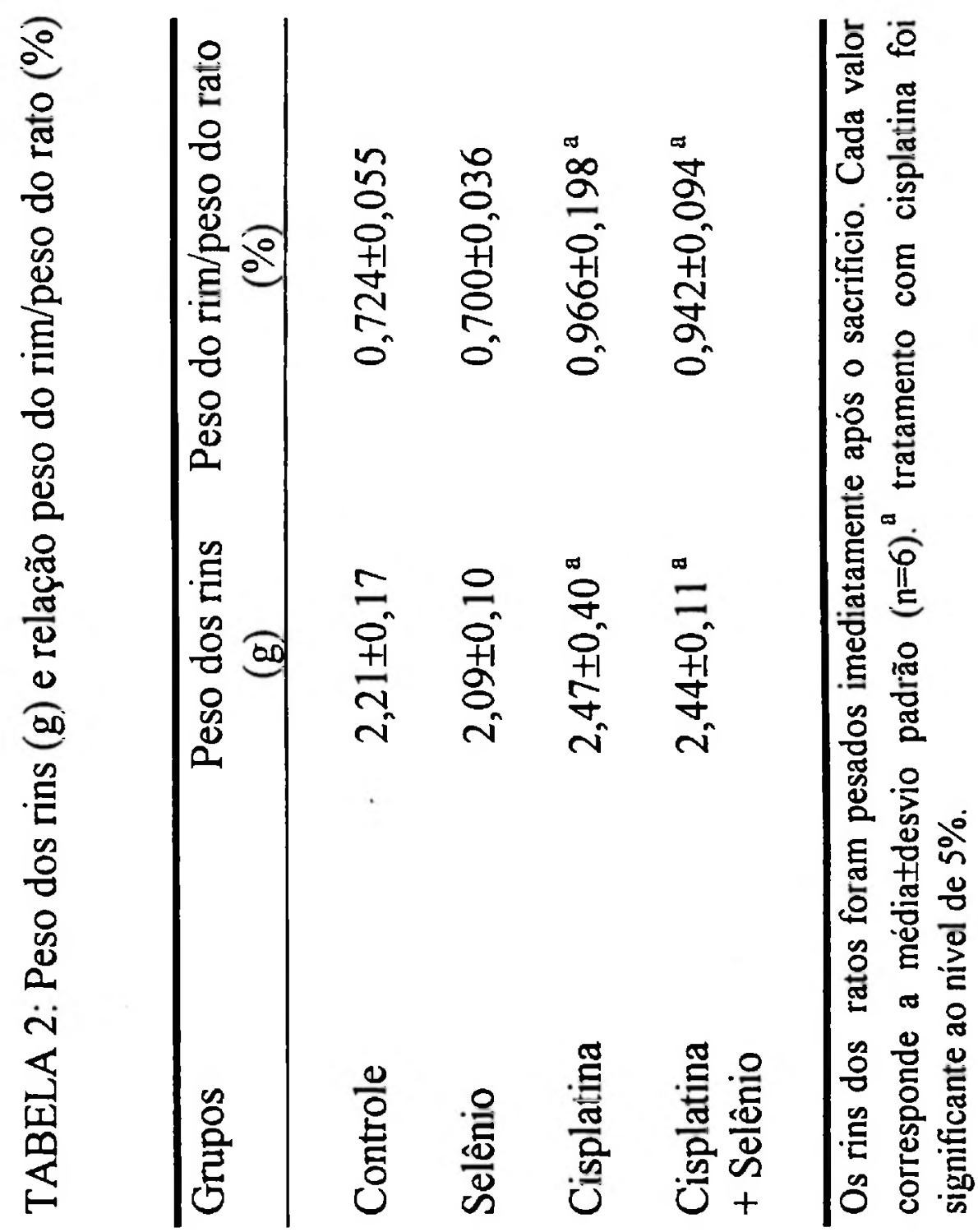




\section{3 - Volume urinário}

O volume urinário diario foi avaliado e as médias de cada grupo são mostradas na Tabela 3 e Figura 2. Os resultados individuais são mostrados em apêndice nas tabelas $18,19,20$ e 21 .

Observou-se um aumento significativo $(\mathrm{p}<0,05)$ do volume urinário no Grupo Selênio no dia da administração do selênio (dia 0 ) com relação ao Grupo Controle, mas nos dias seguintes não foi observado aumento neste grupo. O Grupo Cisplatina teve um aumento significativo $(\mathrm{p}<0,05)$ após a administração da cisplatina (dia 1) que persistiu até o final do experimento. Os ratos do grupo Cisplatina+Selênio apresentaram um aumento significativo $(\mathrm{p}<0,05)$ do volume urinário após o dia 2 que persistiu até o final do experimento. 


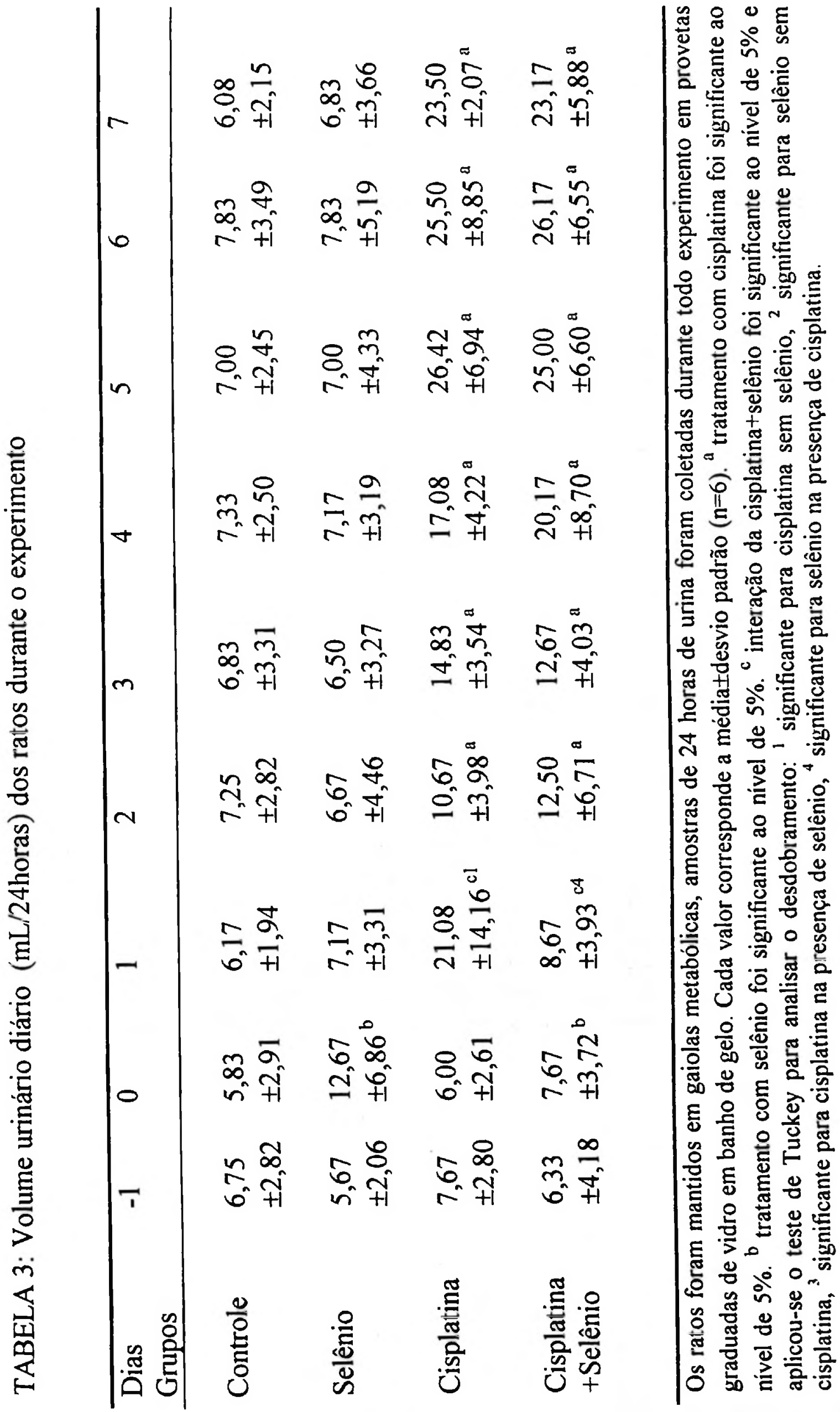




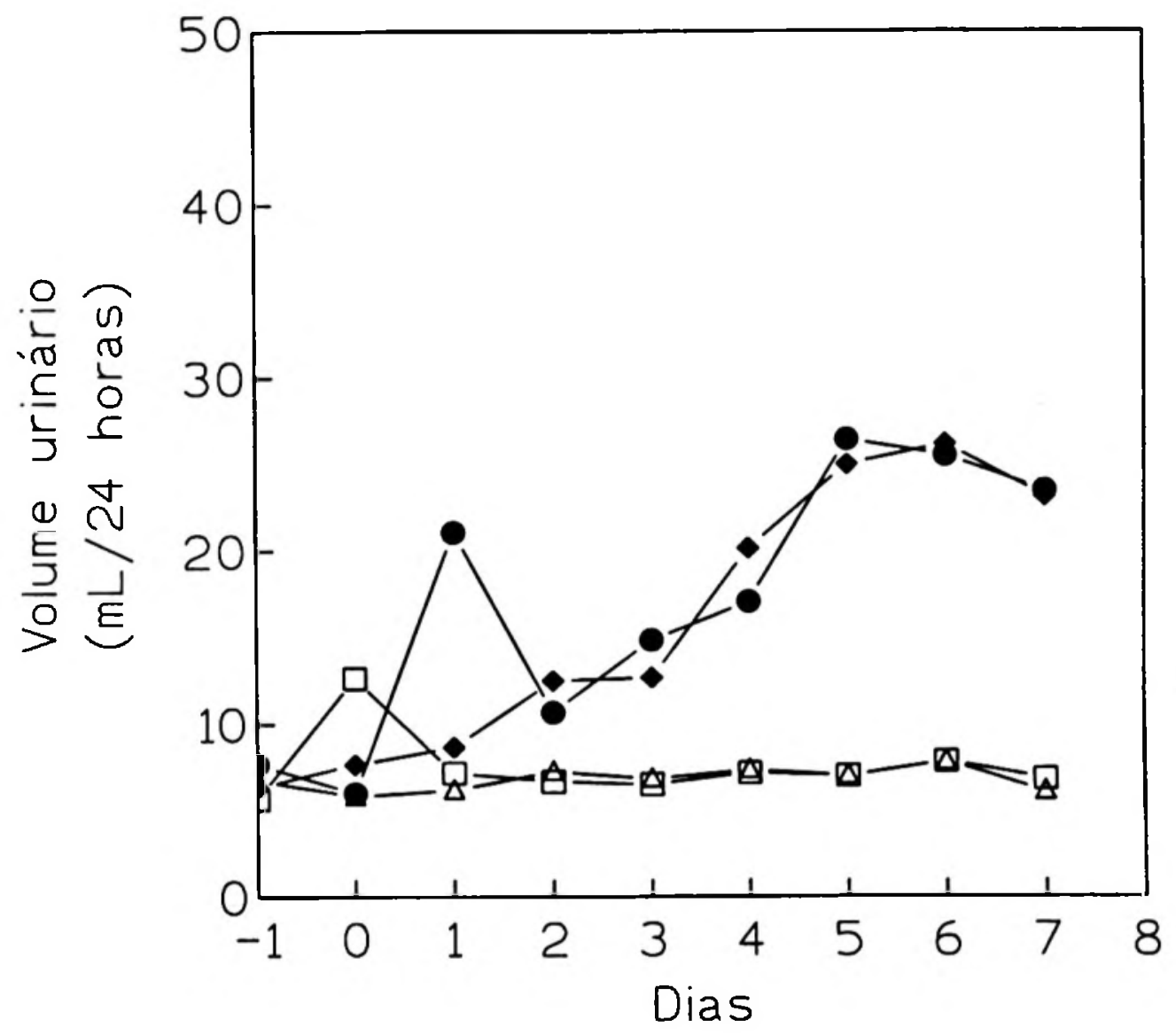

Figura 2 :Volume urinário (mL/24horas) durante o experimento. Efeito do selênio, cisplatina e cisplatina+selênio no volume urinário durante todo o experimento. Os ratos foram mantidos em gaiolas metabólicas, amostras de 24 horas de urina foram coletadas durante todo experimento em provetas graduadas de vidro em banho de gelo. $(\Delta)$ Grupo Controle, $(\square)$ Grupo selênio, (๑) Grupo cisplatina e ( $\bullet$ Grupo Cisplatina+selênio. Cada valor corresponde a média $(n=6)$. 
4.4 - Avaliação da atividade da enzima urinária N-acetil- $\beta-D-$ glicosaminidase (NAG) total e de sua isoenzima $B$

Na Tabela 4 e Figura 3 estão delineados os resultados da atividade da NAG total durante o experimento. Verificou-se um aumento da atividade nos Grupos Cisplatina e Cisplatina + Selênio nos dias 3 e 4, mas não houve diferença significativa entre eles.

A Tabela 5 e a Figura 4 mostram os resultados da atividade da isoenzima B da NAG durante o experimento. Houve aumento da atividade no Grupo Cisplatina nos dias 2, 3 e 4, que não foi observado no Grupo Cisplatina+Selênio. Houve diferença significativa entre os Grupos Cisplatina e Cisplatina+Selênio.

Os resultados individuais são mostrados em apêndice nas tabelas 22 , 23,24 e 25 . 


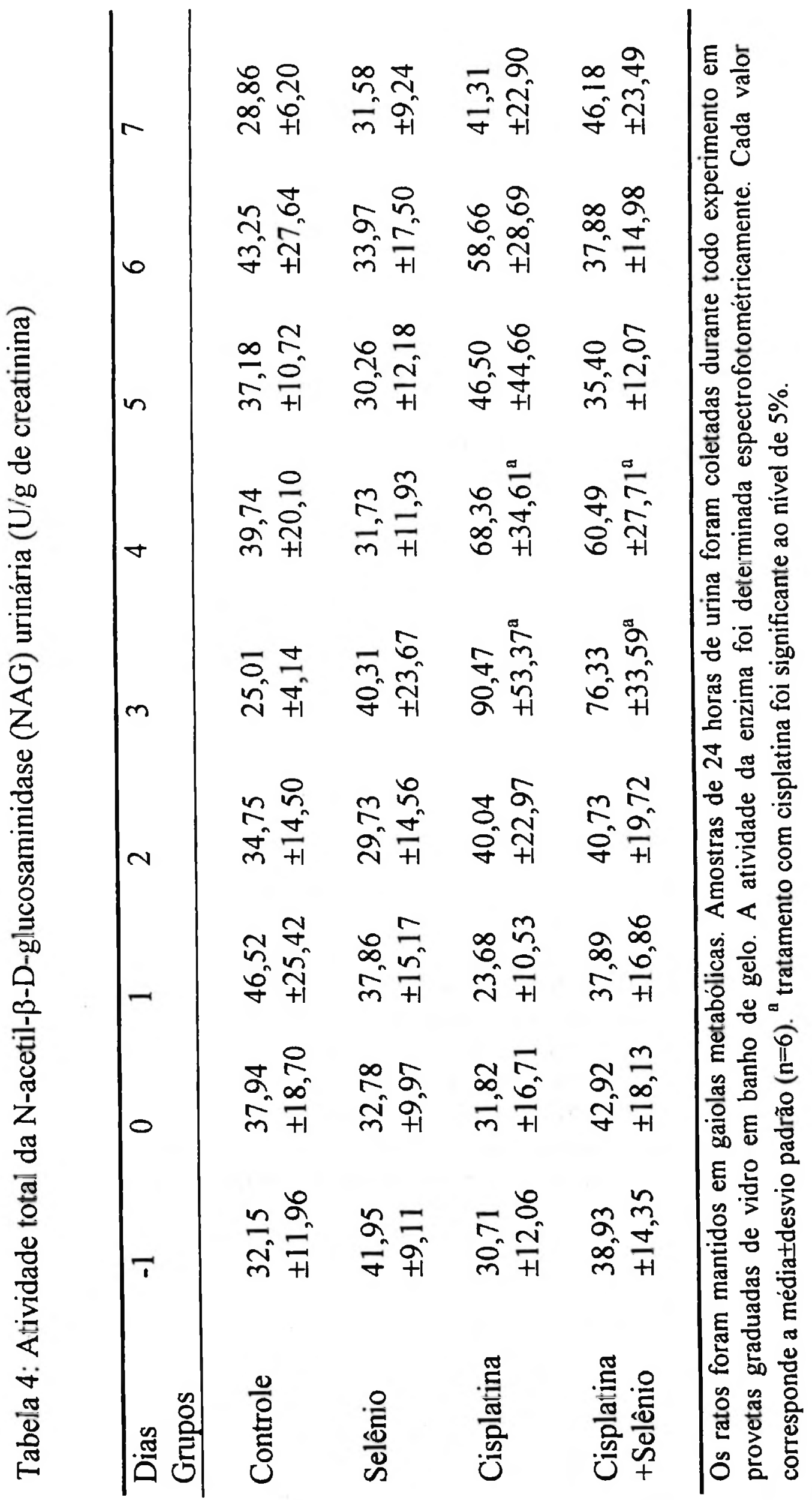




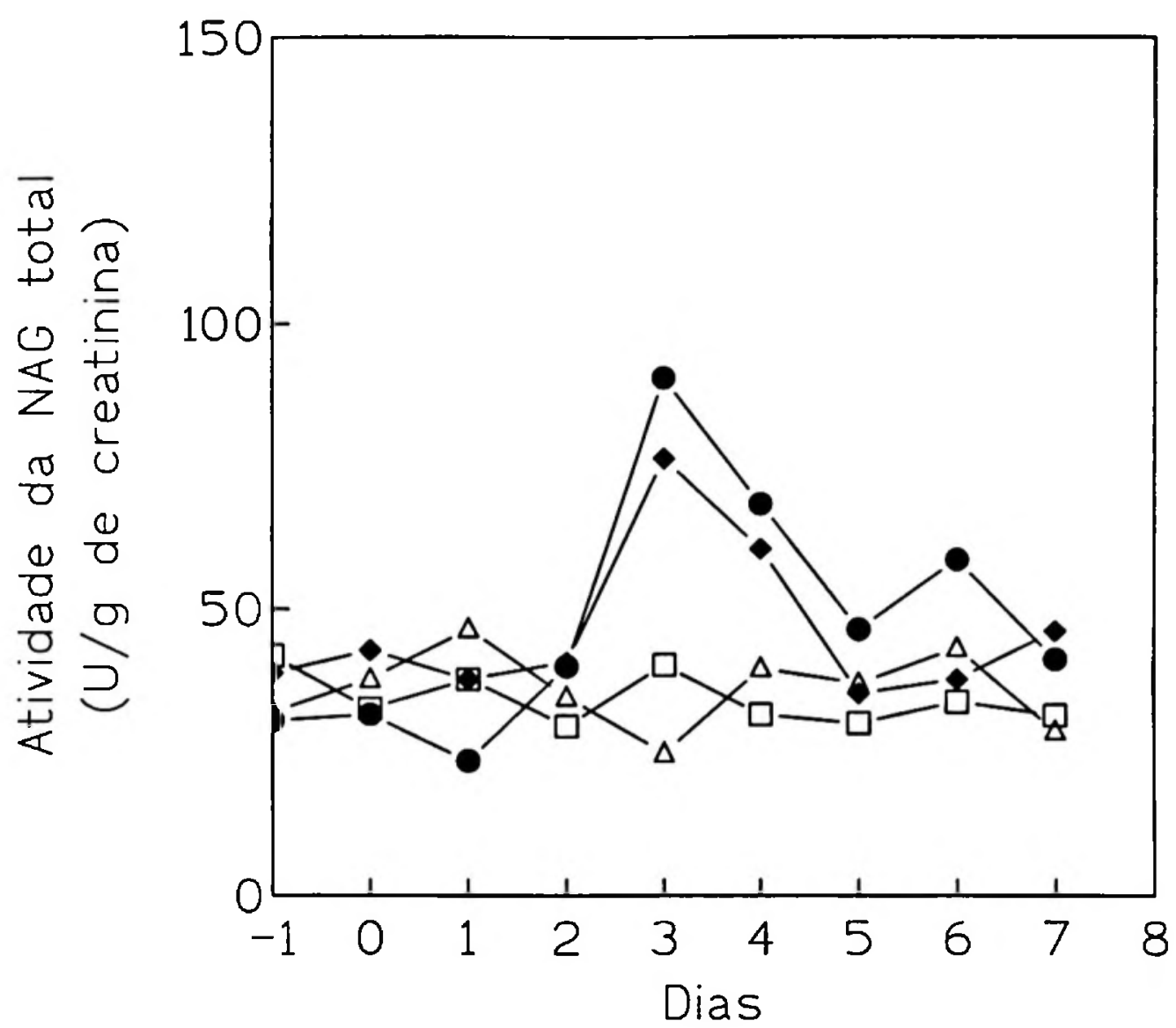

Figura 3 : Atividade da $\mathrm{N}$-acetil- $\beta$-D-glicosaminidase total (NAG) urinária (U/g de creatinina) durante o experimento. Efeito do selênio, cisplatina e cisplatina+selênio na atividade da $N$-acetil- $\beta$ - $D$ glicosaminidase total (NAG) urinária dos ratos durante todo o experimento. Os ratos foram mantidos em gaiolas metabólicas, amostras de 24 horas de urina foram coletadas durante todo experimento em provetas graduadas de vidro em banho de gelo. A atividade da enzima foi determinada espectrofotometricamente. $(\Delta)$ Grupo Controle, ( $\square$ ) Grupo selênio, (๑) Grupo cisplatina e (४) Grupo Cisplatina+selênio. Cada valor corresponde a média $(n=6)$. 


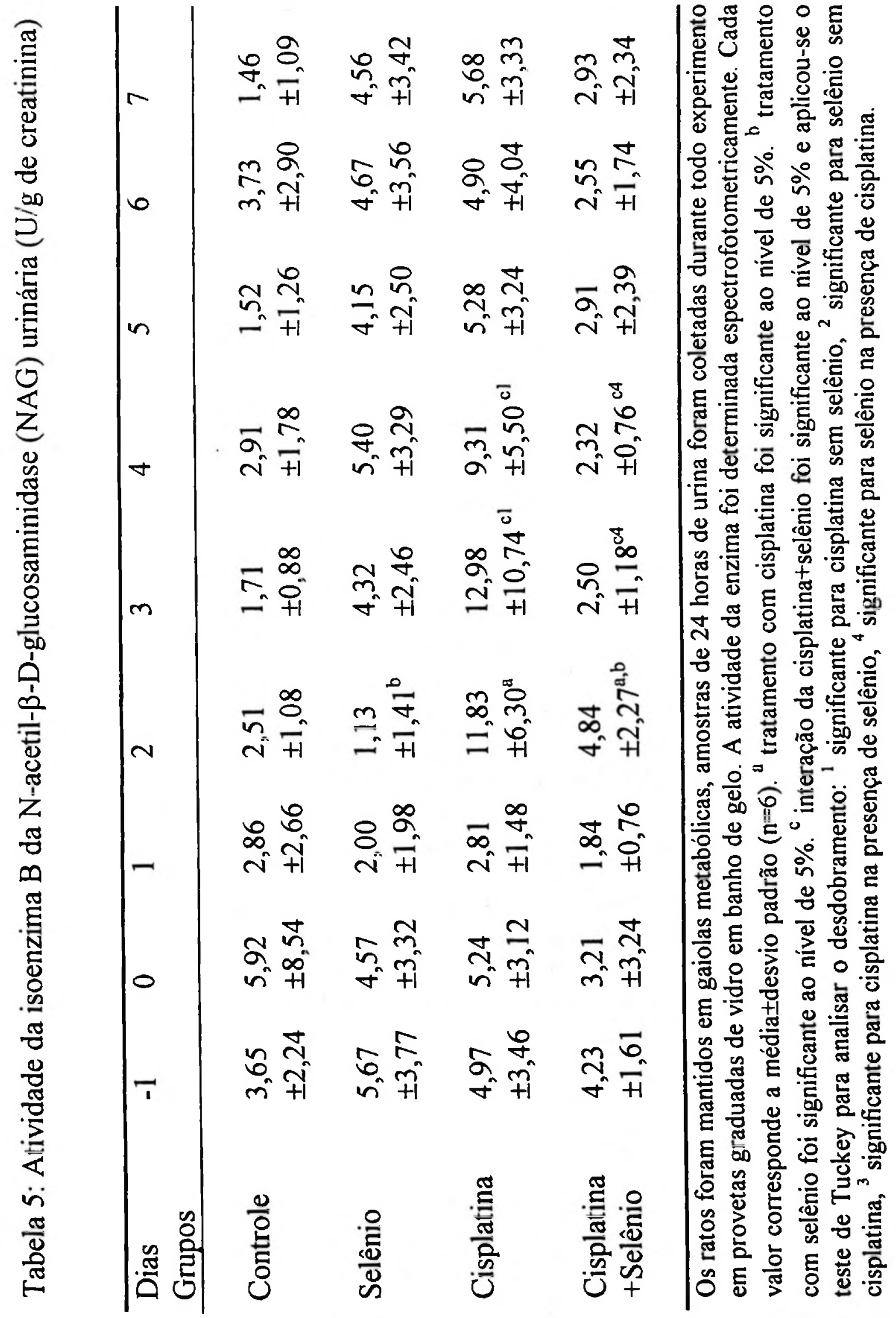




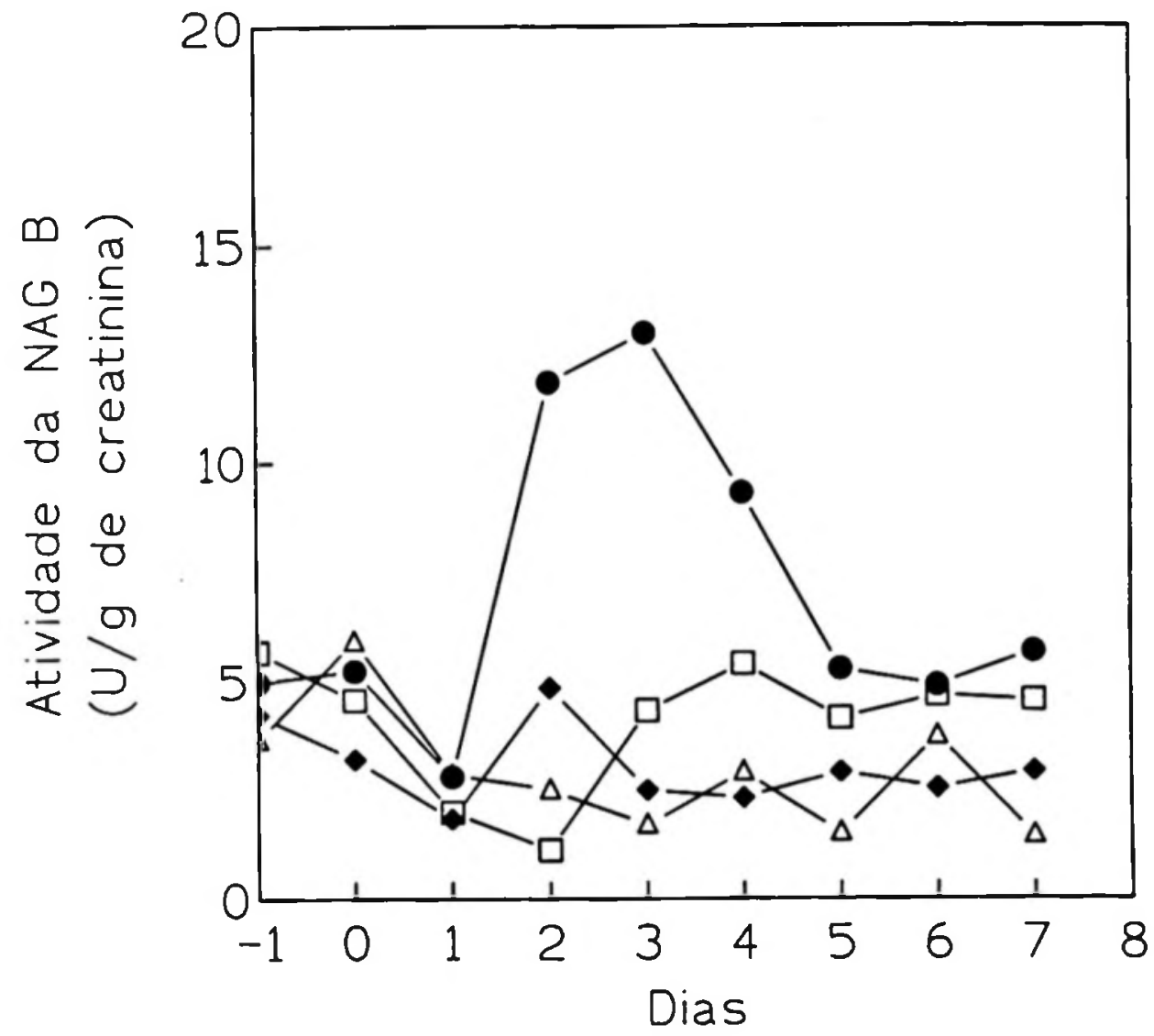

Figura 4 : Atividade da isoenzima $\mathrm{B}$ da $\mathrm{N}$-acetil- $\beta$-D-glicosaminidase (NAG) urinária (U/g de creatinina) durante o experimento. Efeito do selênio, cisplatina e cisplatina+selênio na atividade da isoenzima $B$ da $\mathrm{N}$-acetil- $\beta$-D-glicosaminidase (NAG) urinária dos ratos durante todo $o$ experimento. Os ratos foram mantidos em gaiolas metabólicas, amostras de 24 horas de urina foram coletadas durante todo experimento em provetas graduadas de vidro em banho de gelo. A atividade da enzima foi determinada espectrofotometricamente. $(\Delta)$ Grupo Controle, ( $\square$ ) Grupo selênio, (๑) Grupo cisplatina e ( $\bullet$ Grupo Cisplatina+selênio. Cada valor corresponde a média $(n=6)$. 
4.5 - "Clearance" da creatinina e creatinina plasmática

Os dados do "clearance" da creatinina e creatinina plasmática são apresentados na Tabela 6 e figuras 5 e 6 . Os dados individuais podem ser vistos em apêndice nas tabelas 26 e 27 .

Observou-se uma diminuição significativa $(p<0,05)$ do "clearance" nos Grupos Selênio, Cisplatina, e no Grupo Cisplatina + Selênio. Não houve diferença significativa entre os Grupos Cisplatina e Cisplatina + Selênio.

Quanto aos níveis de creatinina plasmática, observou-se um aumento significativo $(p<0,05)$ nos Grupos Cisplatina e Cisplatina+Selênio, não havendo diferença entre eles. 


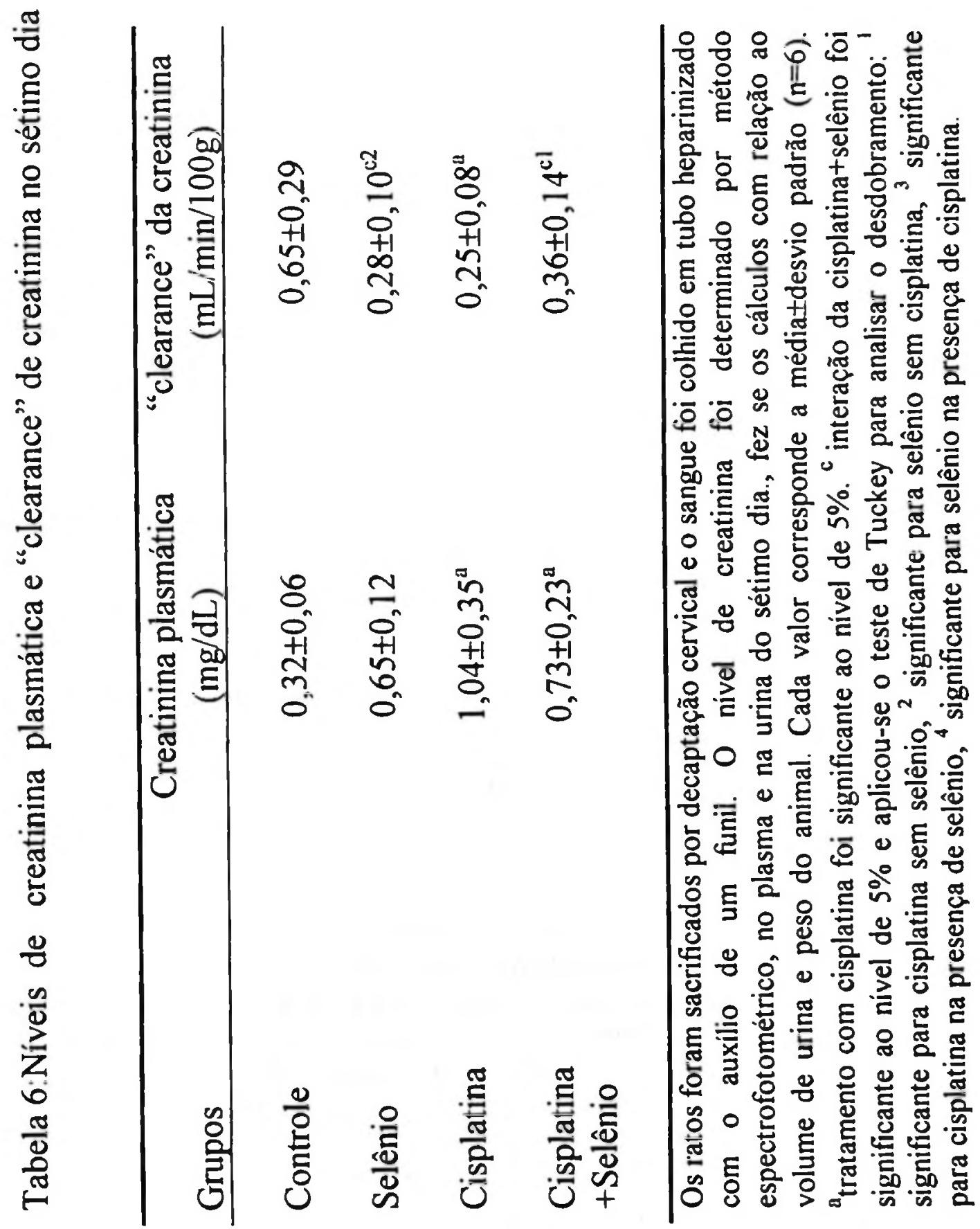




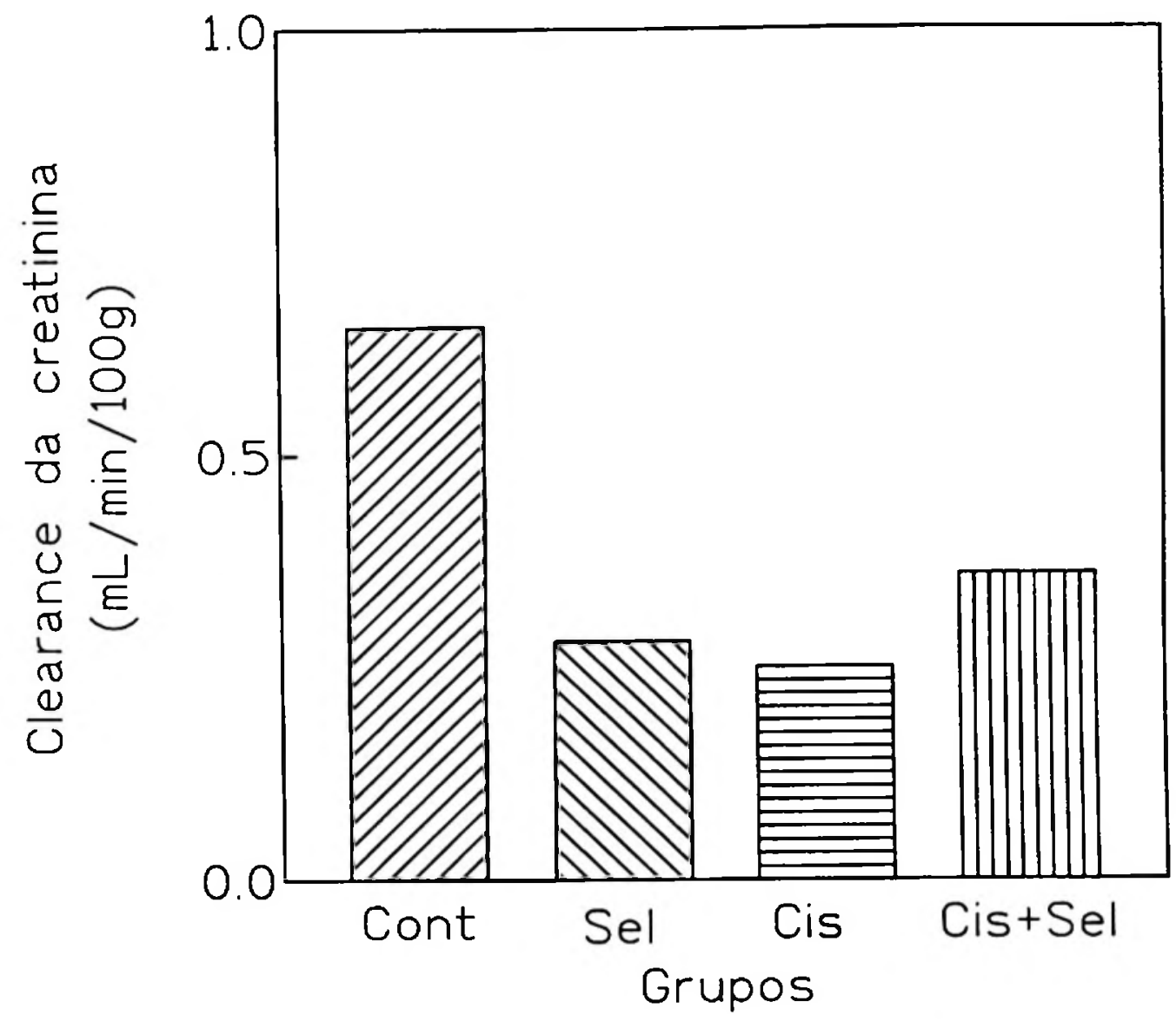

Figura 5: "Clearance" da creatinina dos animais $(\mathrm{mg} / \mathrm{min} / 100 \mathrm{~g}$ ). Efeito do selênio, cisplatina e cisplatina+selênio no clearance da cretinina dos ratos sete dias após o tratamento com cisplatina. Os ratos foram sacrificados por decaptação cervical e o sangue foi colhido em tubo heparinizado com o auxílio de um funil. O nivel de creatinina foi determinado por método espectrofotométrico, no plasma e na urina do sétimo dia, fez se os cálculos com relação ao volume de urina e peso do animal. (Cont) Grupo Controle, (Sel) Grupo selênio, (Cis) Grupo cisplatina e (Cis+Sel) Grupo Cisplatina+selênio. Cada valor corresponde a média $(n=6)$. 


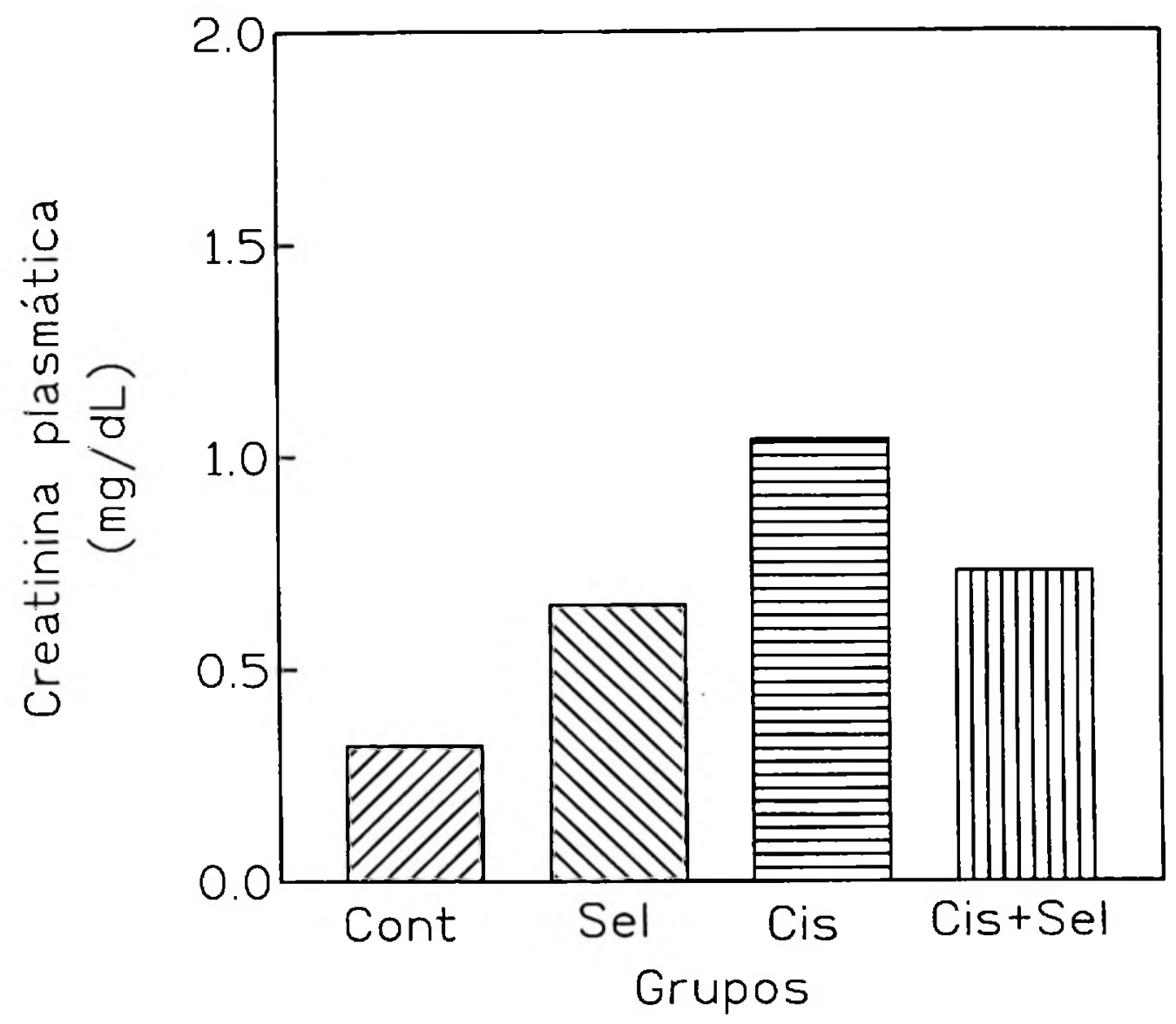

Figura 6 : Creatinina plasmática dos animais $(\mathrm{mg} / 100 \mathrm{~mL})$. Efeito do selênio, cisplatina e cisplatina+selênio no nível de cretinina plasmática dos ratos sete dias após o tratamento com cisplatina. Os ratos foram sacrificados por decaptação cervical e o sangue foi colhido em tubo heparinizado com o auxílio de um funil. $O$ nivel de creatinina foi determinado no plasma por método espectrofotométrico. (Cont) Grupo Controle, (Sel) Grupo selênio, (Cis) Grupo cisplatina e (Cis+Sel) Grupo Cisplatina+selênio. Cada valor corresponde a média $(n=6)$. 
4.6 - Níveis de proteina total na urina

Os níveis de proteína total na urina diários são mostrados na Tabela 7 e Figura 7. Os resultados individuais podem ser vistos em apêndice nas tabelas $28,29,30$ e 31 . Observou-se que houve uma diminuição significativa $(p<0,05)$ nos níveis de excreção de proteínas no Grupo Selênio nos dias 1 e 3 com relação ao Grupo Controle. Nos ratos dos grupos tratados com Cisplatina e Cisplatina+Selênio, verificou-se um aumento significativo dos niveis de proteina na urina do dia 2 até o final do experimento, com relação ao Grupo Controle. 


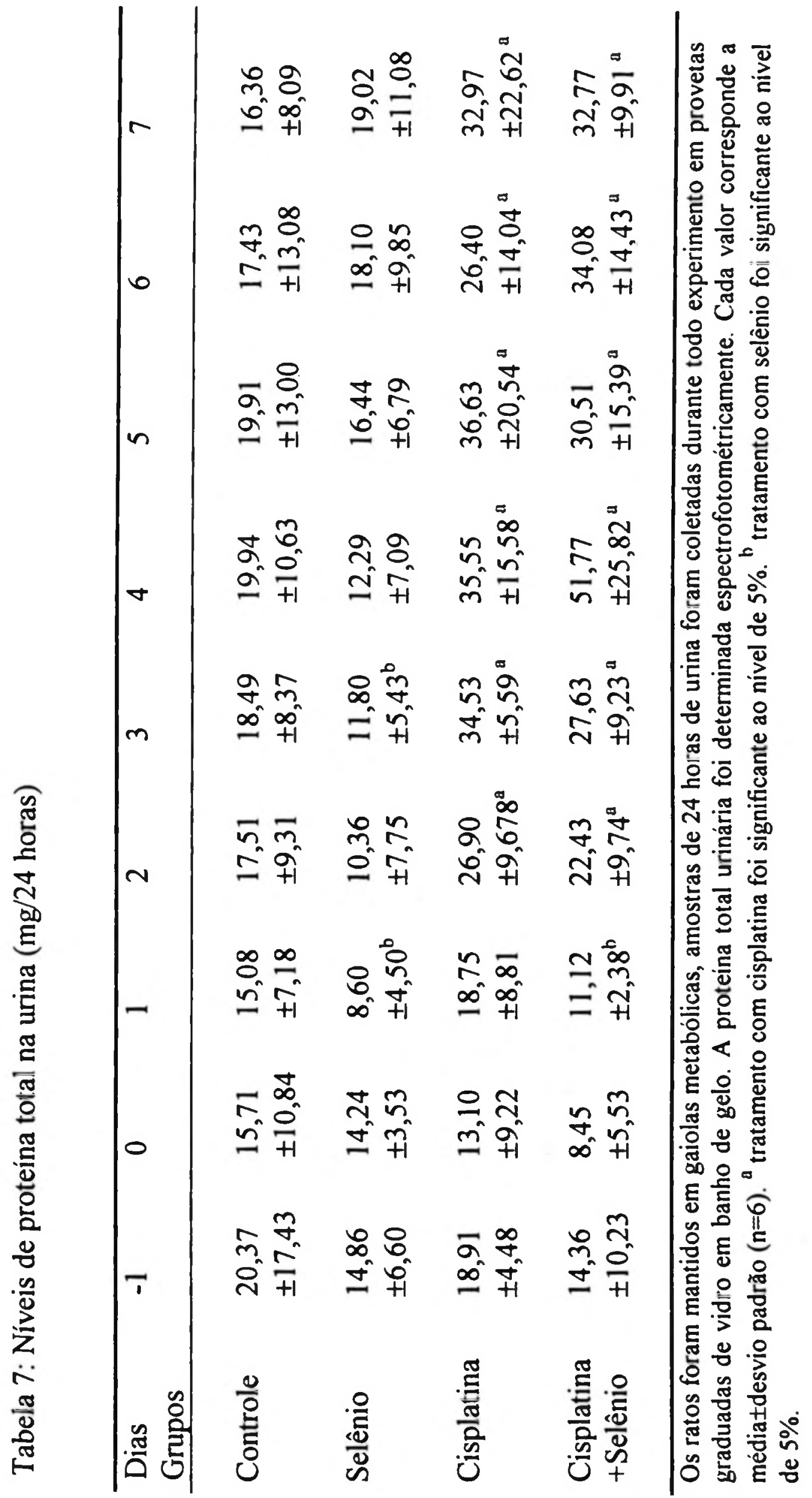




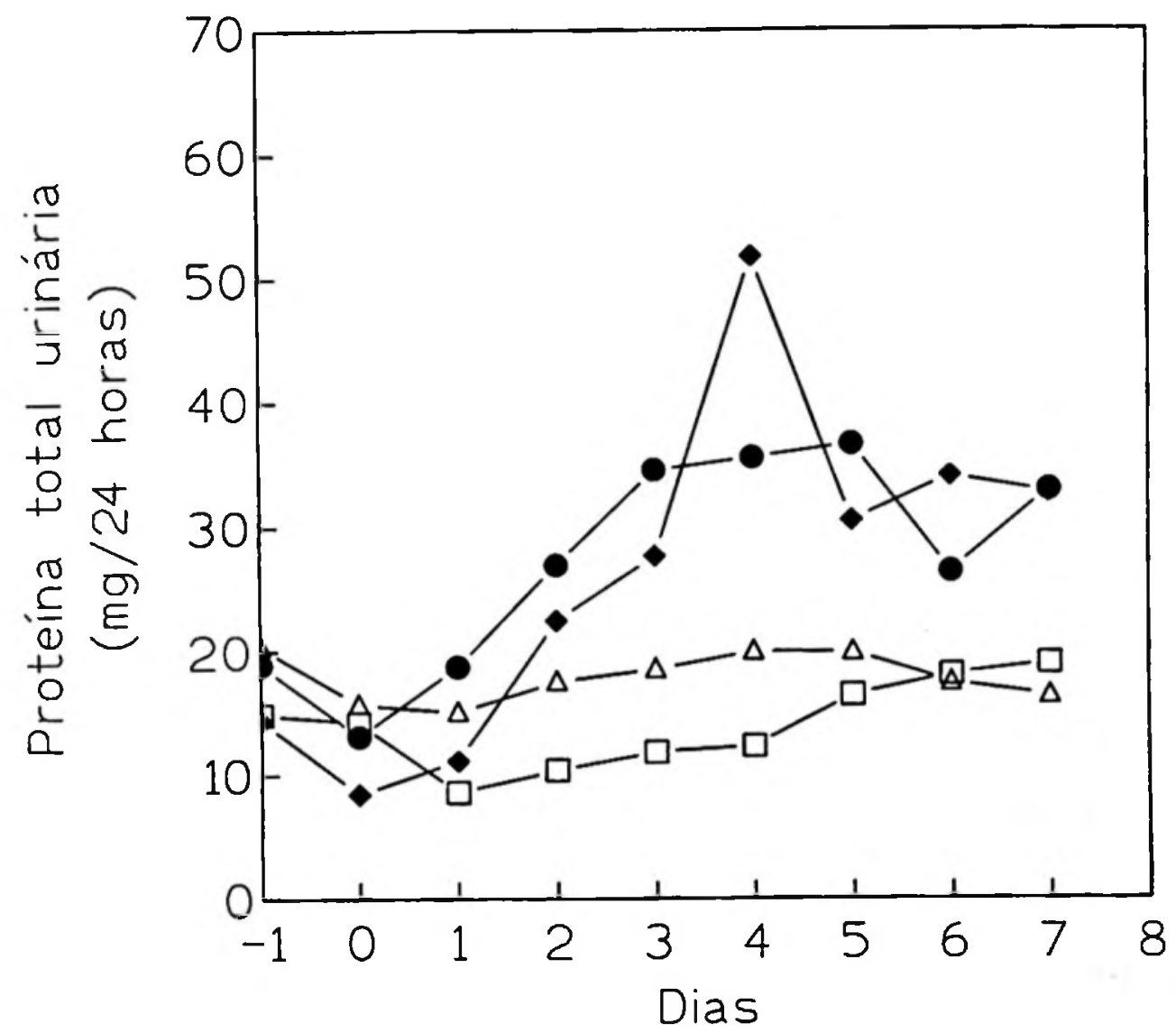

Figura 7 : Níveis de proteína total urinária $(\mathrm{mg} / 24$ horas) durante o experimento. Efeito do selênio, cisplatina e cisplatina+selênio na excreção de proteína total urinária dos ratos durante todo o experimento. Os ratos foram mantidos em gaiolas metabólicas, amostras de 24 horas de urina foram coletadas durante todo experimento em provetas graduadas de vidro em banho de gelo. A proteína total urinária foi determinada espectrofotometricamente. $(\Delta)$ Grupo Controle, ( $\square$ ) Grupo selênio, (๑) Grupo cisplatina e ( $\bullet$ ) Grupo Cisplatina+selênio. Cada valor corresponde a média $(n=6)$. 
4.7 - Níveis de peroxidação lipídica e glutationa nos rins

A avaliação da peroxidação lipídica nos rins foi realizado pela determinação das substâncias reativas ao ácido tiobarbitúrico (SRATB) e os resultados podem ser vistos na Tabela 8 e na Figura 8. Os niveis de substâncias reativas ao ácido tiobarbitúrico foram significativamente maiores nos Grupos Cisplatina e Cisplatina + Selênio.

Os resultados da glutationa (GSH), obtidos pela análise de grupos sulfidrílicos não-ligados à proteína dos quais a glutationa é o principal, são mostrados na Tabela 8 e Figura 9. Os niveis de GSH foram significantemente maiores nos rins dos ratos do Grupo Cisplatina $(\mathrm{p}<0,05)$.

Os resultados individuais são mostrados em apêndice nas tabelas 32 e 33. 


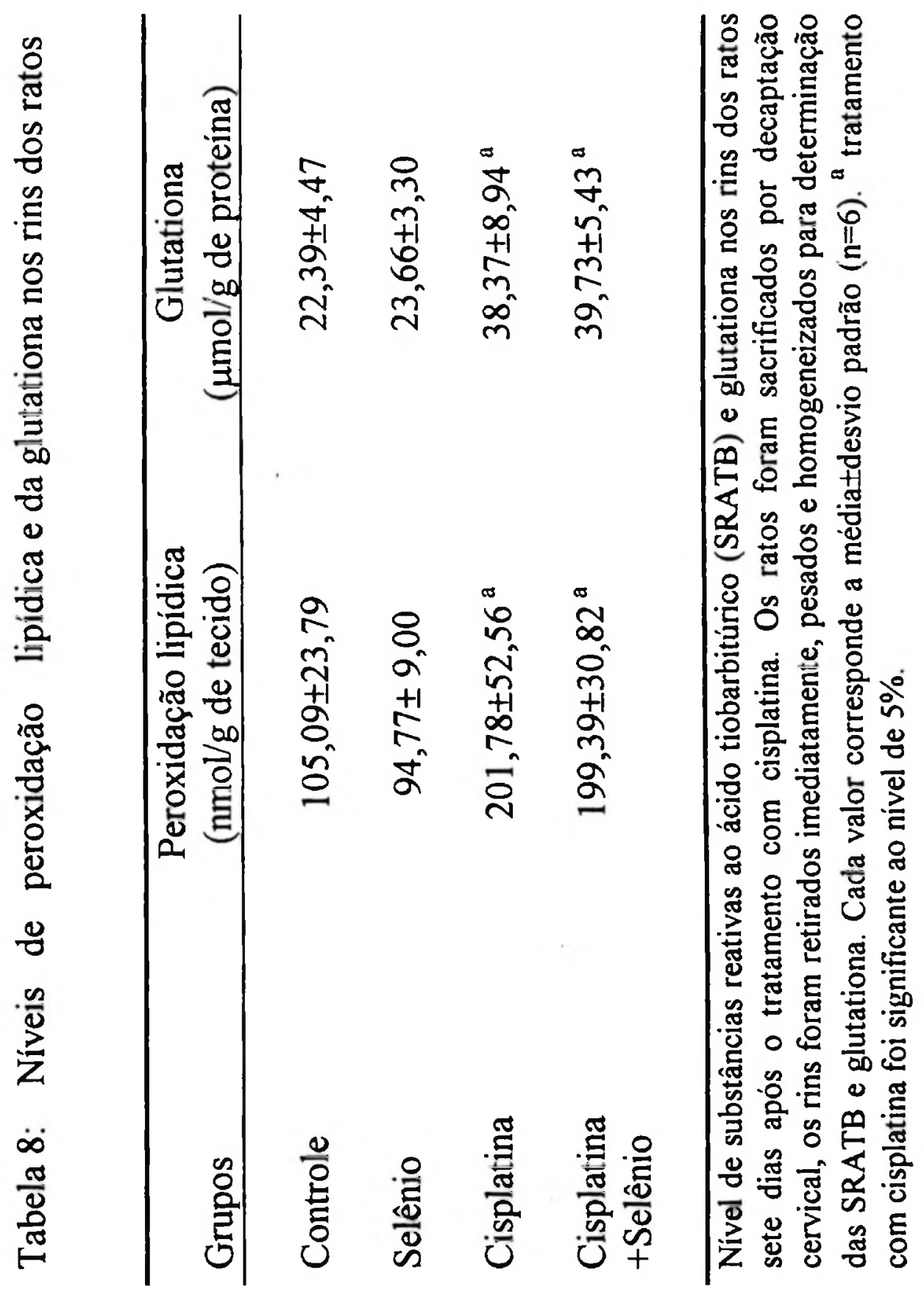




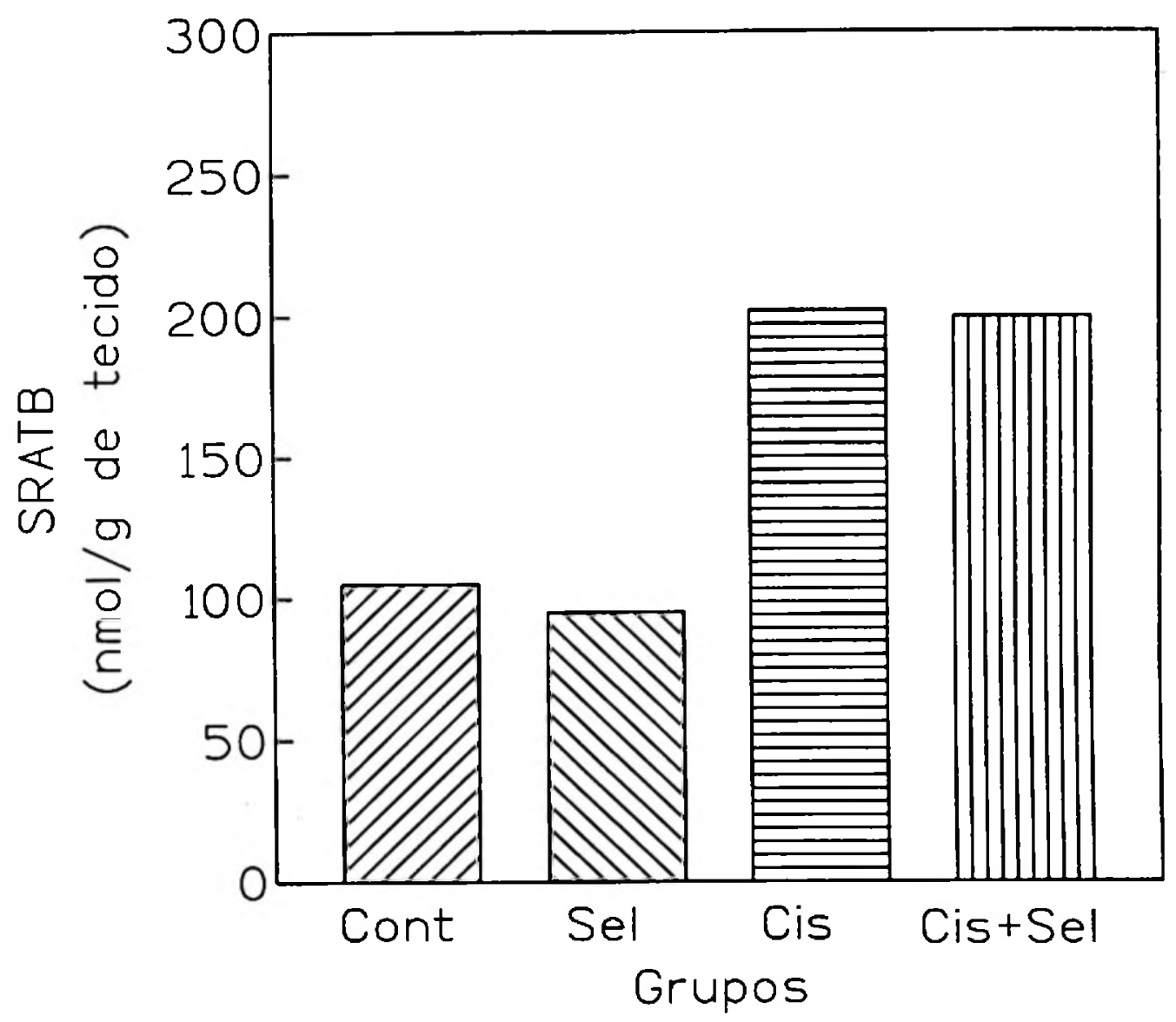

Figura 8 : Niveis de peroxidação lipídica (SRATB) $(\mathrm{nmol} / \mathrm{g}$ de tecido úmido) nos rins dos ratos. Efeito do selênio, cisplatina $e$ cisplatina+selênio no nível de substâncias reativas ao ácido tiobarbitúrico (SRATB) nos rins dos ratos sete dias após o tratamento com cisplatina. Os ratos foram sacrificados por decaptação cervical, os rins foram retirados imediatamente, pesados e homogeneizados para determinação das SRATB por método espectrofotométrico. (Cont) Grupo Controle, (Sel) Grupo selênio, (Cis) Grupo cisplatina e (Cis+Sel) Grupo Cisplatina+selênio. Cada valor corresponde a média $(\mathrm{n}=6)$. 


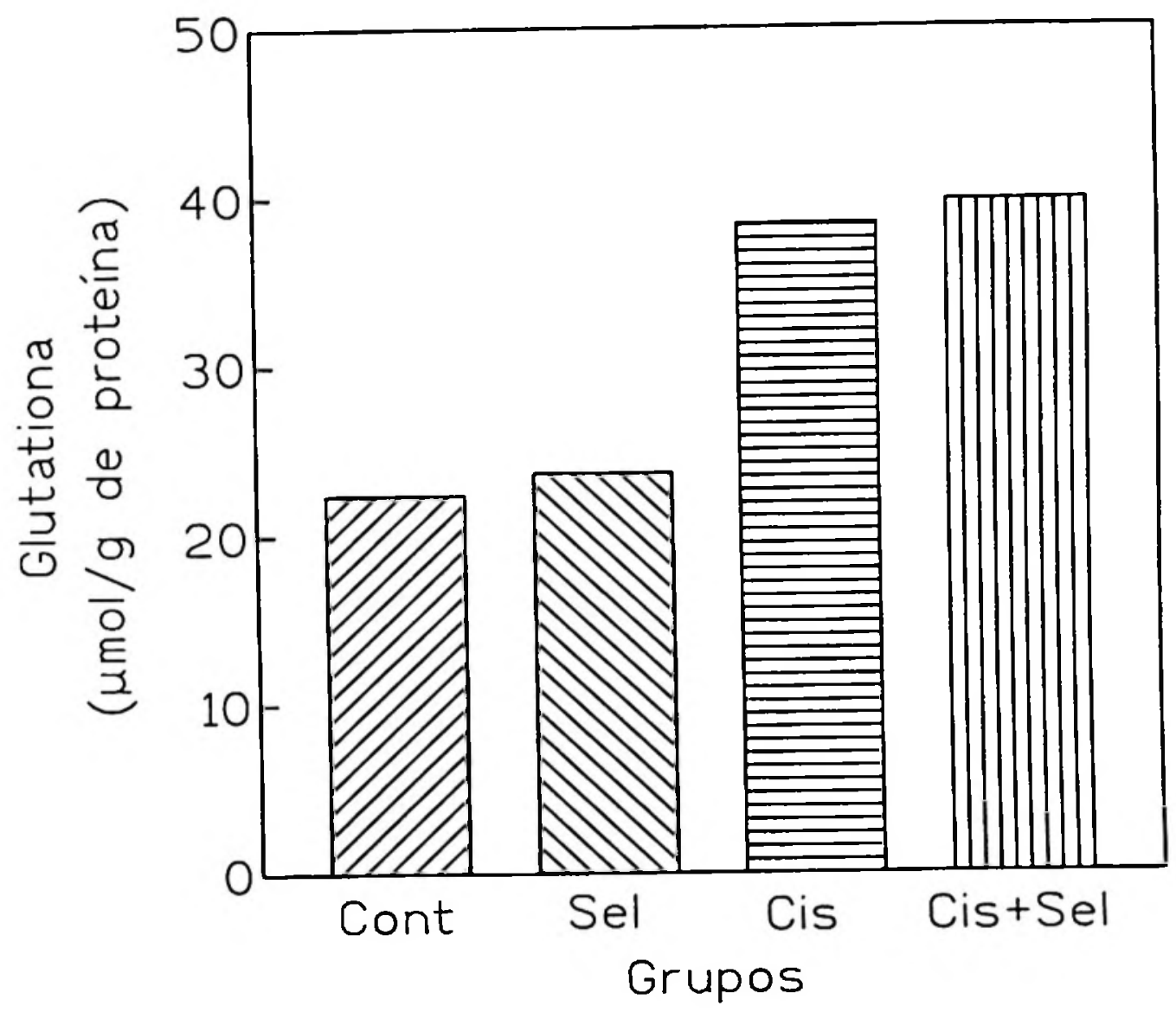

Figura $9:$ Níveis de glutationa ( $\mu \mathrm{mol} / \mathrm{g}$ de proteina) nos rins dos ratos. Efeito do selênio, cisplatina e cisplatina+selênio no nível de glutationa nos rins dos ratos sete dias após o tratamento com cisplatina. Os ratos foram sacrificados por decaptação cervical, os rins foram retirados imediatamente, pesados e homogeneizados para determinação da glutationa por método espectrofotométrico. (Cont) Grupo Controle, (Sel) Grupo selênio, (Cis) Grupo cisplatina e (Cis+Sel) Grupo Cisplatina+selênio. Cada valor corresponde a média $(n=6)$. 


\section{5- DISCUSSÃO}

A cisplatina é o antineoplásico do grupo dos derivados de platina mais utilizado na prática médica. Por ser nefrotóxica e menos mielosupressora que a maioria dos outros antineoplásicos, a cisplatina, utilizada em combinação com outras drogas representa uma boa alternativa terapêutica (Rosenberg, 1985).

Seus efeitos tóxicos foram primeiramente observados em humanos, e depois estudados em animais. Para estudar a nefrotoxicidade da cisplatina pode-se utilizar ratos e cães, pois apresentam praticamente os mesmos efeitos em humanos (Guarino et al., 1985; Daugaard, 1990; Anand \& Bashey, 1993).

Para ratos, em esquema de dose única, as doses mais comuns de cisplatina são de 5 ou $6 \mathrm{mg}$ por quilograma de peso. A dose utilizada nesse estudo foi de $5 \mathrm{mg}$ por quilograma de peso de rato, que é a dose mais utilizada em ratos. Com esta dose verificam-se mudanças morfológicas e funcionais sem perda dos animais (Earhart et al., 1983; Safirstein et al., 1984; Daley-Yates \& McBrien, 1985; Daugaard et al., 1988a; Sugiyama et al., 1989; Zhong et al., 1990; Nagai et al., 1995) o que ocorre freqüentemente com doses maiores de 10mg (Goldstein \& Mayor, 1983; Jones et al., 1985). Apesar de serem doses freqüentemente utilizadas em 
animais, elas são aproximadamente quatro a cinco vezes maiores que as empregadas em seres humanos (Gonzales-Vitale et al., 1977; Jacobs et al., 1980; Tirelli et al., 1985). Salienta-se que, em geral, os animais de laboratório são mais resistentes às drogas que outras espécies, seja quando são realizados estudos funcionais ou de alterações morfológicas (Thiel et al., 1976). A dose utilizada no presente estudo ( $5 \mathrm{mg} / \mathrm{Kg}$ de peso) de cisplatina provocou mudanças no estado funcional renal.

Barnes et al. (1980) e Goldestein \& Mayor (1983), sugerem que a cisplatina seja a causa mais comum de insuficiência renal, em pacientes com câncer. Esta toxicidade orgânica é a que mais interfere com a vida normal dos pacientes, uma vez curados de sua neoplasia maligna (Barnes et al., 1980; Chiuten et al., 1983; Vermoken, 1986; Appenroth et al., 1990).

O propósito do presente estudo foi avaliar o efeito protetor do selênio na nefrotoxicidade induzida pela cisplatina em ratos. $O$ sal utilizado foi o selenito de sódio, composto de selênio que mais protegeu contra a toxicidade induzida pelo mercúrio (Komiya et al., 1977). Doses múltiplas de selenito de sódio já mostraram promover proteção contra a nefrotoxicidade da cisplatina, quando administrado por via subcutânea e intraperitoneal, em camundongos portadores de neoplasias tratados com cisplatina Naganuma et al., 1983; Ohkawa et al., 1988). Também dose única de selenito administrado intravenosamente 1 hora antes da cisplatina em ratos normais, promoveu proteção (Baldew et al 1989). Apesar da via mais comum de administração do selênio ser a via oral, não há citado na literatura estudo que tenha utilizado essa via. 
O mecanismo da proteção do selênio na nefrotoxicidade da cisplatina não está bem definido. Sugiyama et al (1989), usando doses múltiplas de ácido selênico em ratos, sugeriu que a proteção se deve a manutenção dos níveis de glutationa peroxidase, uma selenoenzima antioxidante dependente de selênio. $O$ autor acredita que o mecanismo da nefrotoxicidade da cisplatina esteja relacionada a lesão oxidativa. Baldew et al. (1991) sugerem que a cisplatina reage com um metabólito do selênio, o metilselenol. Ligando-se a este, a cisplatina pode ser detoxificada do organismo, ou pode liberar a platina ligada à grupos tióis de proteínas, restaurando, dessa maneira, a atividade biológica da proteína, ou ainda pode competir com a platina pelos grupos tióis de proteínas no rim.

É conhecido que a nefrotoxicidade induzida pela cisplatina em ratos resulta em aumento do volume urinário (Safirstein et al., 1981; Clifton et al, 1982; Gordon et al., 1982; Daugaard et al., 1987, 1988a); aumento relativo do peso dos rins (Mason \& Edwards, 1985; Edelweiss, 1991); aumento da creatinina plasmática (Safirstein et al., 1981; Baldew et al., 1989; Li et al., 1994, 1995); diminuição do "clearance" da creatinina (Safirtein et al., 1981, Chopra et al., 1982; Haragsim \& Zima, 1992); aumento da atividade da enzima urinária N-acetil- $\beta$-D-glicosaminidase (Jones et al., 1980; Daugaard et al., 1987, Haragsim \& Zima, 1992); proteinúria (Daugaard et al., 1988a) e também em perda de peso (Ammer et al., 1993).

Em humanos, utiliza-se a medida direta da função renal, por elevação da uréia e creatinina séricas, proteinúria, ou hiperuricemia (Gislain et al., 1990). Outros índices de determinação da função renal incluem diminuição do "clearance" da creatinina, aumento da excreção de enzimas tubulares 
(Gonik et al, 1973) e excreção urinária de $\beta 2$-microglobulina (Gimurray, 1989).

A perda de peso tem sido constantemente observada em animais tratados com cisplatina. No presente trabalho a cisplatina causou perda significativa de peso dos ratos (Tab.1 e Fig.1). Esta pode ser decorrente da toxicidade gastrintestinal da droga ou da diminuição da ingestão de alimentos ou de ambas (Berry et al., 1984; Mason \& Edwards, 1985a, b; Ohkawa et al., 1988; Edelweiss, 1991). Ammer et al. (1993) verificaram que há uma correlação entre a redução da função renal e a perda de peso. Sugerem os autores que a perda de peso pode ser considerada como um indício simples do estado citotóxico de um indivíduo. Quanto a perda de peso ocasionada pelo selênio no presente trabalho, ela pode ser observada na Tab.1 e Fig.1. Pode-se afirmar que esta perda de peso não foi causada pelo estresse da administração por gavagem, visto que os animais do grupo controle e cisplatina receberam água, também por gavagem e ganharam peso. Este efeito de perda de peso após administração do selênio já foi observado por Berry et al. (1984), trabalhando com camundongos aos quais administraram ácido selênico $4 \mathrm{mg} / \mathrm{kg}$ (intraperitoneal). Estes autores observaram leve perda de peso e nenhuma morte. $\mathrm{Na}$ dose de $6 \mathrm{mg} / \mathrm{kg}$, observaram $80 \%$ de sobrevivência e severa perda de peso com recuperação na 3a semana após tratamento. Quando administraram o selênio $(4 \mathrm{mg} / \mathrm{kg}$ ) com a cisplatina, observaram aumento da taxa de sobrevivência e diminuição da perda de peso. Concluíram os autores, que o selênio pode ser utilizado durante a administração de cisplatina para diminuir sua nefrotoxicidade. Porém, 
ressaltaram que em altas doses, o selênio pode ser tóxico. A DL50 via oral do selenito de sódio é de $7 \mathrm{mg} / \mathrm{Kg}$ de peso (Cumminins \& Kimura, 1971). A biodisponibilidade do selenito é alta, de aproximadamente 95\% (Brown et al, 1972).

Com relação ao peso dos rins, Edelweiss (1991) observou um aumento relativo do peso dos rins, mais acentuado entre 4 e 7 dias após dose única de cisplatina. Após análise histológica, concluiu ser por um aumento generalizado das células que sofreram processo degenerativo hidrópico e edema intersticial, acrescido de alterações hemodinâmicas e de permeabilidade celular. Mason e Edwards (1985) já haviam observado o aumento do peso relativo dos rins de ratos, que se manteve até o oitavo dia após a administração da cisplatina. Levi et al. (1980) relataram uma diminuição do peso dos rins após três dias da administração da cisplatina intraperitoneal $(6 \mathrm{mg} / \mathrm{Kg})$ nos ratos. Observou-se no presente estudo (Tab.2) aumento do peso dos rins e da relação peso rim/peso do rato nos ratos do Grupo Cisplatina e Cisplatina+Selênio.

Tem-se observado em vários trabalhos, aumento da diurese após a administração da cisplatina (Safirstein et al., 1981;Clifton et al., 1982; Gordon et al., 1982; Daugaard et al., 1986, 1987 e 1988). Várias teorias foram formuladas para explicar este aumento da diurese, observado após a administração da cisplatina. Clifton et al. (1982) e Gordon et al. (1982), trabalhando com ratos, observaram uma alteração na concentração renal no primeiro e oitavo dia após a administração da cisplatina. Segundo os autores, esta alteração observada no primeiro dia após a cisplatina, foi decorrente da alteração na síntese e/ou liberação de 
vasopressina. Gordon et al., (1982) sugerem que oito dias após a administração da cisplatina, a alteração da concentração renal é decorrente, em parte, de uma diminuição da tonicidade intersticial.

Daugaard et al. (1986), trabalhando com cães, propuseram que o aumento inicial na diurese não estava associado com as alterações da atividade da vasopressina ou queda na tonicidade papilar, mas era devido ao aumento da carga de soluto dos túbulos proximais para os outros segmentos mais distais do néfron, decorrente da diminuição da taxa de reabsorção proximal de sódio e água. Este volume maior de fluido que foi ofertado, deveria ser reabsorvido pelas porções mais distais do néfron. Parece que a reabsorção de sódio dos túbulos distais também é comprometida. Dessa maneira, uma maior quantidade de água e sódio são eliminados, aumentando o volume urinário. A partir desse e de outros experimentos, Daugaard et al. (1986, 1987 e 1988) propuseram que a nefrotoxicidade é iniciada por uma alteração da função tubular proximal renal tanto em cães, como em ratos ou humanos, com um envolvimento predominante da porção distal dos túbulos em humanos.

Pode-se sugerir a partir dos dados analisados, que o selênio impediu a elevação inicial da diurese observada nas primeiras 24 horas após tratamento com cisplatina (Tab. 3 e Fig.2).

A lesão tubular proximal pode ser verificada pela determinação da atividade de enzimas na urina. A enzimúria está associada com o efeito agudo e não crônico, pois a urina é um sistema aberto. As enzimas mais freqüentemente utilizadas são a $\mathrm{N}$-acetil-B-D-glicosaminidase (NAG), r glutamiltransferase, lisozima e fosfatase alcalina (Dubach et al., 1988). 
A dosagem da atividade da NAG na urina é um método não invasivo que denuncia lesão renal precoce, mais especificamente lesão tubular (Price 1992). Ela é encontrada na forma de várias isoenzimas, em nível do cortex renal. Pode-se encontrar duas isoenzimas principais, a forma A e B, que são hidrolases lisossomais que estão envolvidas no catabolismo de glicoproteínas (Wiktorowicz et al., 1977). A isoenzima NAG A é a forma encontrada em maior proporção na urina normal, enquanto que um aumento na excreção total com aumento da isoenzima NAG B denuncia lesão tecidual (Ellis et al., 1975; Tucker et al., 1980).

O aumento da atividade da NAG urinária é originária predominantemente das células dos túbulos renais, pois o seu alto peso molecular, impede sua filtração através dos glomérulos, a não ser que eles estejam lesados (Hultberg \& Ravnskov, 1981). As isoenzimas A e B estão localizadas no túbulo contorcido proximal e o aumento da excreção da NAG B na urina, depois de uma lesão renal, reflete a intensidade da lesão tubular proximal (Bourbouzet al., 1984, a).

A excreção diferencial pode ser explicada pelo fato de que a forma A (ácida) é localizada na parte solúvel do lisossoma e é perdida na urina durante a exocitose. Em contraste, a forma B (básica) está associada com a membrana lisossomal e, portanto, não pode ser perdida na urina a não ser que a célula esteja lesada (Bourbouzet al., 1984, b).

$O$ ensaio da NAG tem sido utilizado como indicador de nefrotoxicidade induzida por drogas tais como aminoglicosideos, ciclosponina e cisplatina (Jones et al., 1980; Daugaard et al., 1988; Gibey et al., 1990; Lemos et al., 1991; Sanchez-Bernal et al., 1991; Lin et al., 
1994) e para avaliar o envolvimento secundário dos rins em outras doenças (Lang et al., 1992; Melichar et al., 1995).

Como há variações da excreção da NAG durante o dia (Lakatua et al., 1982), optou-se coletar urina 24 horas, para evitar este efeito e conseguir maior volume de urina. Para corrigir variações de volume urinário os resultados foram expressos em unidades da enzima pelos valores de creatinina urinária (Jung, 1991).

A cromatografia de exclusão molecular (Sephadex G 25) é utilizada para separar pigmentos e ácido ascórbico, pois este impede a hidrólise do substrato p-nitrofenol-N-acetil-B-D-glicosaminide (Horak et al., 1981). A uréia parece não interferir em testes que usam este substrato, principalmente em urina de ratos (Jung et al., 1991).

As concentrações de substrato utilizadas no teste de Horak et al (1981) são padronizadas para humanos, mas não há problema utilizá-lo para ratos, pois o $\mathrm{Km}$ da NAG urinária de ratos é menor que de humanos para este substrato (Jung et al., 1991).

Apesar da sensibilidade ser uma vantagem na avaliação da lesão renal por enzimas urinárias, ela também pode acarretar uma grande variabilidade dos dados. A determinação da atividade de enzimas urinárias é muito útil quando utilizadas em conjunto com outros testes de integridade renal (Price, 1992).

Observou-se nas Tab. 4 e 5 e Fig. 3 e 4, aumento da atividade da NAG total nos dias 3 e 4 nos Grupos Cisplatina e Cisplatina+Selênio. Porém verificou-se aumento da atividade da isoenzima B da NAG somente no Grupo Cisplatina. Levando-se em consideração que um 
aumento na atividade da isoenzima $B$ da NAG é um melhor indicador de lesão renal do que a atividade total (Ellis et al., 1975; Tucker et al., 1980) pode-se sugerir que o selênio promoveu uma proteção parcial a lesãos precoces nos túbulos proximais.

A diminuição na taxa de filtração glomerular, verificada pelo aumento dos níveis de creatinina plasmática foi observada do terceiro ao sétimo dia após a administração da cisplatina em ratos (Safirstein et al., 1981). A lesão tubular pode contribuir para a diminuição da taxa de filtração glomerular, observada durante o tratamento com drogas nefrotóxicas. A diminuição da taxa de filtração glomerular, determinada pelo "clearance" da creatinina, foi observada em ratos após administração de 5-10mg de cisplatina/Kg de peso em ratos (Safirstein et al., 1981, Chopra et al., 1982). Segundo Baldew et al. (1991), o pico de creatinina para ratos ocorre cinco dias após uma dose única de cisplatina. Li et al. (1994) observaram um aumento de 2,5 a 5 vezes nos níveis de creatinina plasmática no quarto e oitavo dia após dose única de cisplatina $(6 \mathrm{mg} / \mathrm{Kg})$. Em doenças renais, os valores de creatinina sérica não aumentam significantemente até que a função renal esteja consideravelmente comprometida. (Winkler \& Parra, 1937). A creatinina plasmática ou sérica é um índice bastante utilizado em experimentos com cisplatina para avaliar a sua nefrotoxicidade. A diminuição do "clearance" e o aumento dos níveis de creatinina plasmática no Grupos Cisplatina e Cisplatina+Selênio (Tab.6 e Fig 5 e 6 ), indica que a cisplatina foi nefrotóxica e que o selênio não promoveu proteção em nível de função glomerular. 
A excreção de proteína na urina pode ser modificada qualitativa e quantitativamente quando há um comprometimento renal. Quando a lesão é glomerular observa-se um aumento da excreção de proteínas de alto peso molecular, como a albumina. Quando a lesão é tubular o aumento da excreção é menor. As proteínas são de menor peso molecular, pois são normalmente filtradas e reabsorvidas pelos túbulos. A principal delas é a $\beta_{2}$-microglobulina (Peterson, 1969).

Daugaard et al., (1988b) observaram em pacientes, uma diminuição do "clearance" da $\beta_{2}$-microglobulina e aumento da atividade da NAG no final da infusão da cisplatina (5 dias), enquanto que os níveis de albumina e proteína total foram encontrados 3 a 4 dias depois do final da infusão.

Quando se determina a $\beta_{2}$-microglobulina, avalia-se a lesão tubular e quando se determina a proteína total avalia-se indiretamente a função glomerular, pois a maior parte da proteína excretada é albumina. A proteinúria glomerular pode ser o resultado de um aumento da permeabilidade da membrana do glomérulo devido tanto a um alargamento dos poros, quanto às perdas das cargas negativas fixadas nas paredes dos capilares glomerulares, as quais reduzem a restrição eletrostática. Parece que a restrição pelas cargas negativas dos capilares glomerulares reduz a filtração de poliânions tais como a albumina (Brenner et al., 1976; Bridges et al., 1982).

Como podemos observar na Tab.7 e Fig.7, os animais do Grupo Cisplatina apresentaram um aumento dos niveis de proteína a partir do dia 2 até o final do experimento. Esses resultados obtidos com ratos 
tratados com cisplatina estão de acordo com os obtidos por Daugaard et al. (1988) quanto ao aumento da excreção de proteína total na urina de humanos, que ocorre após 3 ou 4 dias da administração da cisplatina. Os animais tratados com cisplatina+selênio, também apresentaram um aumento da excreção de proteínas total na urina, ou seja, o selênio não evitou a proteinuria induzida pela cisplatina nos animais .

O mecanismo do efeito nefrotóxico induzido pela cisplatina não está ainda estabelecido. A diminuição da nefrotoxicidade, com o uso de substâncias antioxidantes (Zhong et al., 1990; Vail et al., 1993) e a diminuição da atividade de enzimas antioxidantes durante o uso da cisplatina, sugerem que o mecanismo da nefrotoxicidade da cisplatina pode estar relacionado com a formação de radicais livres e a peroxidação lipídica (Sadzuka et al., 1992; Babu et al., 1995). Esta ocorre quando radicais livres reagem com ácidos graxos poliinsaturados de fosfolipídeos de membranas celulares, resultando em desarranjo dessas estruturas. Dependendo da extensão da peroxidação lipídica pode haver comprometimento de certas funções, podendo levar a célula à morte.

Ao final da reação de peroxidação lipídica há formação de várias substâncias por degradação dos lipídeos oxidados, dentre elas o malondialdeído que tem sido quantificado para avaliar a peroxidação lipídica. O método mais comumente utilizado para quantifica-lo é a reação colorimétrica com ácido tiobarbitúrico que é inespecífico, ou seja, outras substâncias além do malondialdeído reagem com este ácido. Devido a esta inespecificidade, é comum expressar os resultados como niveis de substâncias reativas ao ácido tiobarbitúrico e não níveis de 
malondialdeído. Esta reação com ácido tiobarbitúrico tem sido muito utilizada e tem demonstrado uma boa correlação com o grau de peroxidação lipídica por vários autores, tanto em experimento in vitro como in vivo, como metodologia indireta para avaliar a peroxidação lipídica (Sugihara et al., 1987; Bombart, 1989; Zhong et al., 1990; Vermeulen \& Baldew, 1992; Torri et al., 1993; Zhang \& Lindup, 1993; Babu et al., 1995).

Evitou-se no presente estudo períodos de jejum e uso de anestésicos, pois Liu et al (1994) verificaram que esta combinação aumentou os níveis de substâncias reativas ao ácido tiobarbitúrico em figado de ratos .

Para avaliar os níveis de peroxidação lipídica realizou-se a determinação das substâncias reativas ao ácido tiobarbitúrico nos rins dos animais. Observa-se na Tab. 8 e Fig. 8 , que os ratos dos Grupos Cisplatina e Cisplatina+Selênio apresentaram um aumento significativo dos níveis de substâncias reativas ao ácido tiobarbitúrico, ou seja, a peroxidação lipídica pode estar envolvida no mecanismo da nefrotoxicidade induzida pela cisplatina, como já foi observado em outros trabalhos (Sugihara et al., 1987; Bombart, 1989; Zhong et al., 1990; Sadzuka et al., 1992; Vail et al., 1993; Zhang $\&$ Lindup, 1993; Babu et al., 1995). O selênio, na dose e via utilizada no presente estudo não protegeu os rins dos animais da peroxidação lipídica.

O organismo de seres aeróbicos desenvolveu sistemas de defesa antioxidante para se proteger da produção constante de espécies reativas do oxigênio as quais podem reagir com proteínas, DNA, lipídios 
causando lesões na célula. Os principais sistemas de proteção celular são realizados por pequenas moléculas e por enzimas endógenas (Lash, 1995; Gérard-Monnier \& Chaudiere, 1996).

A glutationa (GSH), principal tiol não ligado a proteína do organismo, é um tripeptídeo ( $\gamma$-glutamil-L-cisteinil-glicina). Ela é um potente nucleófilo que participa de uma variedade de reações de detoxificação, tanto por reação direta com radicais livres, como por reações de detoxificação enzimática. A glutationa entra como substrato em reações de redução de hidroperóxidos a álcoois e água, catalisadas pelas enzimas glutationa peroxidases, na qual ela é oxidada para a forma de dissulfeto (GSSG). A glutationa oxidada (GSSG) retorna novamente à sua forma reduzida (GSH) por uma reação catalisada pela enzima glutationa redutase na presença de NADPH (Shan et al., 1990). A determinação dos níveis da glutationa pode ser realizada através de método colorimétrico inespecífico ou método enzimático. $O$ método colorimétrico quantifica grupos sulfidrila não ligados a proteína, dos quais a glutationa corresponde a aproximadamente $90 \%$. Apesar de ser inespecífico este método é muito utilizado em experimentos in vitro e in vivo (Levi et al., 1980; Zhang \& Lindup, 1993). No presente estudo utilizou-se um método colorimétrico preconizado por Sedlak \& Lindsay (1968).

Em experimentos in vitro Dedon \& Borsh (1987) e Ishikawa \& Ali Osman (1993) estudaram a reação de derivados de platina, incluindo a cisplatina, com aminoácidos que contém enxofre, proteínas, peptídeos e nucleófilos não-biológicos. Os autores observaram que a cisplatina reage diretamente com a glutationa numa razão de 2 moléculas 
de glutationa para 1 de cisplatina. Também em experimento in vitro, Zhang \& Lindup (1993) trabalhando com mitocôndria de cortex de rim de ratos incubadas com cisplatina, verificaram que houve diminuição dos niveis de glutationa precocemente ao aumento dos niveis de substâncias reativas ao ácido tiobarbitúrico, método indireto de avaliação de peroxidação lipídica. Os autores sugerem que a diminuição dos níveis de glutationa é um acontecimento que precede a peroxidação lipídica do tecido. Em experimentos in vivo, uma diminuição dos níveis de glutationa nos rins foi observada em ratos após dose única $(5 \mathrm{mg} / \mathrm{Kg})$ de cisplatina 24 horas posteriores à administração de cisplatina (Singh, 1989). Levi et al. (1980), trabalhando com ratos que receberam uma dose única de cisplatina $(6 \mathrm{mg} / \mathrm{Kg})$ determinaram os níveis de grupos tióis total e grupos tióis não ligados a proteínas (glutationa). Observaram após 3 dias da administração da cisplatina, diminuição dos níveis de grupos tióis total e aumento dos níveis de glutationa (grupos tióis não ligados a proteína), sendo que os autores não sugeriram mecanismo para este aumento. No presente estudo, os níveis de glutationa (Tab.8 e Fig.9) foram determinados sete dias após dose única de cisplatina e observamos elevação em ambos os grupos, Cisplatina e Cisplatina+Selênio, confirmando os achados anteriores sugerindo que o selênio não interfere neste aumento. 


\section{6-CONCLUSÃO}

$O$ estudo do efeito do selênio na nefrotoxicidade induzida pela cisplatina sugere que o selênio administrado por gavagem 24 horas antes de uma dose única de cisplatina, administrada intraperitonealmente, não protegeu os ratos da nefrotoxicidade induzida pela cisplatina. Porém considerando-se os resultados de volume urinário e da isoenzima B da NAG pode-se sugerir que o selênio promoveu uma proteção parcial das alterações precoces nos túbulos proximais.

-A cisplatina mostrou-se nefrotóxica, pois:

- causou perda significativa do peso corporal dos ratos, assim como um aumento do peso dos rins e da relação peso dos rins / peso do rato,

- causou aumento significativo do volume urinário,

- causou aumento significativo da isoenzima $B$ da $\mathrm{N}$-acetil- $\beta$-Dglicosaminidase (NAG) urinária nos dias 2,3 e 4,

- causou diminuição significativa do "clearance" da creatinina e aumento da creatinina plasmática,

- causou aumento significativo da excreção de proteína total na urina dos ratos. 
- O mecanismo da nefrotoxicidade da cisplatina parece estar relacionada com a peroxidação lipídica, pois:

- A cisplatina causou aumento do nível de substâncias reativas ao ácido tiobarbitúrico (SRATB) e de glutationa nos rins dos ratos. 


\section{7-REFERÊNCIAS BIBLIOGRÁFICAS*}

AL-SARRAF, M. et al. Cisplatin hydratation with and without mannitol diuresis in refractory disseminated malignant melanoma: a southwest oncology group study. Cancer Treat. Rep., v.66, p.31-35, 1982.

AMMER, U. et al. Cisplatin nephrotoxicity: site of functional disturbance and correlation to loss of body weight. Renal Physiol. Biochem., v. 16, p. 131-145, 1993.

ANAND, A.J. \& BASHEY,B. Newer insights into cisplatin nephrotoxicity. Ann. Pharmacother. v.27, p.1519-1525, 1993.

APPENROTH, D. et al. Age dependent differences in the functional and morphological impairment of kidney following cisplatin administration. Exp. Pathol, v38, p.231$239,1990$.

* De acordo com as normas recomendadas pelo grupo de estudos de Referências Bibliográficas do SIBI que desenvolveu estudos comparando a NB66/78 e NBR-6023/89. As abreviaturas dos títulos dos periódicos seguem o Chemical Abstracts sevice source index (Cassi) 1990. 
AULL, L.J. et al. The effect of platinum complexes on seven enzymes. Biochim. Biophys. Acta, v.571, p.352-358, 1979.

BABU, E. et al. Cisplatin induced nephrotoxicity and the modulating effect of glutathione ester. Mol. Cell. Biochem., v. 144, p. 7-11, 1995.

BALDEW, G. et al. Selenium-induced protection against cis-diaminedichloroplatinun (II) nephrotoxicity in mice and rats. Cancer Res., v.49, n.11, p.3020-3, 1989.

BALDEW, G. et al. The mecanism of interaction between cisplatin and selenite. Biochem. Pharmacol., v.41,n 10, p. 1429-1437, 1991.

BALIGA, R. et al. Effect of selenium-deficient diet in experimental glomerular disease. Am J. Physiol., v. 263, p. F56-F61, 1992.

BARNES, J.L. et al. Studies on the pathophysiology of acute renal failure. IV. Protective effect of dithiothreitol following administration of mercuric chloride in rats. Virchows Arch. (B), v.32, p. 201-206, 1980.

BARROS, E.J.G. et al. Effect of cisplatin on glomerular hemodynamics. Brazilian J. Med. Biol. Res., v.22, p.1295-1301, 1989.

BERRY, J.P. et al. Effects of selenium in combination with cis-diamminedichloroplatinum (II) in the treatament of murine fibrosarcoma. Cancer Res., v. 44, p. 2854-2868, 1984. 
BERRY, M. J. et al. Type-I oidothyronine deiodinase is a selenocysteine-containing enzyme. Nature, v. 349, p.438-440, 1991.

BERTOLERO, F. \& LITEREST, C.L. Changes in renal handling of platinum in cisplatinum-treated rats following induction of metabolic acidosis or alkalosis. Res. Communic. Chem. Pathol. Pharmacol., v.36, p.273-285, 1982.

BOMBART, G. Cisplatin-induced changes in cytochrome P-450, lipid peroxidation and drug-metabolizing enzime activies in rat kidney cortex. Toxicol. Letter, v.48, p. 193199, 1989.

BOMBART, G. \& ORFILA, C. Cisplatin nephrotoxicity in lead-pretreated rats: enzimatic and morphological studies. Toxicol. Lett. v.50, p.237-247, 1990.

BOURBOUZE, $R$ et al Distribuition of $N$-acetyl- $\beta$-D-glucosaminidase isoenzymes along the rabbit nephron. Kidney Int., v.25, n.4, p.636-642, 1984 a.

BOURBOUZE, R. et al Localisation subcellulaire des isoenzymes de la N-acetyl- $\beta$-Dglucosaminidase du cortex renal de lapin. Cell. Mol. Biol., v.30, n.1, p.67-74, 1984 b.

BRADFORD, Marion M. A rapid and sensitive method for the quantitation of microgram quantities of protein utilizing the principle of protein-dye binding. Anal. Biochem, v. 72, n. 1-2, p.248-254, 1976. 
BRADY, H.R. et al. Mitochondrial injury: an early event in cisplatin toxicity to renal proximal tubules. Am. J. Physiol., v.258, p.F1181-F1187, 1990.

BRENNER, B.M. et al. Transport of molecules across renal glomerular capillaries. Physiol. Rev., v. 56, p. 502-534,1976.

BRIDGES, C.R. et al. Glomerular charge alterations in human minimal changes nephropathy. Kidney Int., v.22, p. 677-684, 1982.

BROWN, D.G. et al. Effect of dietary selenium on gastrointestinal absortion of $75 \mathrm{SeO} 3=$ in the rat. Internat. J. Vit. Nutr. Res., v.42, p.588-591, 1972

CHAUDIERE, J. La glutathion peroxydase: un élément central du systéme de protection de nos cellules. In: Douste-Blazyl, L.; Mendy, F. Biologie des lipides chez l'homme, Edition Lavosier. p.137-154, 1988.

CHIUTEN, D.et al. Is there cumulative or delayed toxicity from cis-platinum? Cancer, v.52, p.211-214, 1983.

CHOIE, C. et al. Acute and chronic cisplatin nephropathy in rats. Lab. Invest., v.44, p.397-402, 1981.

CHOPRA, C.et al. Cisdiamminedichloroplatinum-induced acute renal failure in the rat. Kidney Int, v.21, n.1, p.54-64, Jan. 1982 
CHRISTENSEN J. M. et al. Tissue specificity of selenoprotein gene expression in rats. $\underline{\text { J. }}$ Nutr. Biochem., v 6, p. 367-372, 1995.

CHU, G.. Cellular responses to cisplatin. J. Biol. Chem., v. 269, n. 2, p. 787-790, 1994.

CLAYTON, D.A. et al. The abscence of a pyrimidine dimer repair mechanism in mammalian mitochondria. Proc. Natl. Acad. Sci., v.71, p.2777-2781, 1974.

CLAYTON, D.A. Replication of animal mitochondrial DNA. Cell, v.28, p. 693-705, 1982.

CLIFTON, G.G. et al Early polyuria in the rat following single-dose cisdiamminedichloroplatinum (II). J. Lab. Clin. Med., v. 100, n. 5, p. 659-670, 1982.

CORNELISON, T.L. \& REED, E. Nephrotoxicity and hydration management for cisplatin, carboplatin, and ormoplatin Gynecol. Oncol., v.50, p.147-158, 1993.

CUMMININS, L.M. \& KIMURA, E.T. Safety evaluation of selenium sulfide antidandruff shampoos. Toxicol. Applied Pharmacol., v. 20, p.89-96, 1971.

CVITKOVIC E. et al. Improvement of cis-dichlorodiammineplatinum (NSC 119875): therapeutic index in animal model. Cancer, v.39, p.1357-1361, 1977.

DALEY-YATES, P.T. \& McBRIEN, D.C.H The inhibition of renal ATPase by cisplatin and some biotransformation products. Chem. Biol. Interact., v.40, p.325-334, 1982. 
DALEY-YATES, P.T. \& McBRIEN, D.C.H A study of the protective effect of chloride salts on cisplatin nephrotoxicity. Biochem. Pharmacol.., v.34, p.2363-2369, 1985.

DALEY-YATES, P.T. \& McBRIEN, D.C.H. Cisplatin metabolites in plasma, a study of their pharmacokinetics and importance in the nephrotoxic and antitumorour activity of cisplatin. Biochem. Pharmacol., v.33, p.3063-3070, 1984.

DAUGAARD, G. et al. Acute effect of cisplatin on renal hemodynamics and tubular function in dog kidneys. Renal Physiol., v. 3, p. 308-316, 1986.

DAUGAARD, G. et al. Functional and histophatological changes in dog kidneys after administration of cisplatin. Renal Physiol., v.10, p.54-64, 1987.

DAUGAARD, G. et al. Effect of cisplatin on proximal convoluted and straight segments of the rat kidney. J. Pharmacol. Exp. Ther., v. 244, n. 3, p. 1081-1085, 1988 a.

DAUGAARD, G. et al. Renal tubular function in patients treated with high-dose cisplatin. Clin. Pharmacol. Ther., v. 44, p. 164-172, 1988 b.

DAUGAARD, G. Cisplatin nephrotoxicity: experimental and clinical studies. Danish Med Bull., v.37, p.1-12, 1990.

DeCONTI, R.et al. Clinical and pharmacological studies with cisdiamminediclhoroplatinum (II). Cancer Res., v.33, n.6 , p.1310-1315, 1973. 
DEDON, P.C. \& BORCH, R.F. Caracterization of reation of platinum antitumor agents with biologic and nom-biologic sulfur-containing nucleophiles. Biochem. Pharmacol., v.36, p.1955-1964, 1987.

DENTINO, M. et al. Long term effects of cis-diamminedichloride platinum (CDDP) on renal structure and function in man. Cancer, v.41, n.4, p.1274-1281, 1978.

DOBYAN, D.C. et al. Mechanisms of cis-platinum nephrotoxicity. II morphological observations. J. Pharmacol. Exp. Ther., v.213, p.551-556, 1980.

DUBACH, U.C., Le HIR, M., GANDHI, R. Use of urinary enzymes as markers of nephrotoxicity. Toxicol. Letter, v.46, n.1-3, p.193-6, 1988.

EARHART, R.H. et al Improvement in the therapeutic index of cisplatin (NSC 119875) by pharmacologically induced chloruresis in the rat. Cancer Res., v.43, p.1187-1194, 1983.

EDLWEISS, M.I.A. Modelo experimental de nefrotoxicidade da cisdiamminedichloroplatinum (II): estudo morfológico dos efeitos agudos e crônicos. São Paulo, 1991. 222p. Tese (Doutorado) - Faculdade de Medicina da Universidade de São Paulo.

ELLIS, B.G. et al Presence of serum and tissue forms of N-acetyl- $\beta$-D-glucosaminidase in urine from pacients with renal disease. Clin Chim Acta, v.64, p.195-202, 1975. 
ESAKI, N. et al. Enzymatic synthesis of selenocysteine in rat liver. Biochemistry, v. 20, p. $4492-4496,1981$.

FIELD, M.J. et al. Acute cisplatin nephrotoxicity in the rat: evidence for impaired entry of sodium into proximal tubule cells. Pflugers Arch., v.414, p.647-650, 1989.

FILLASTRE, J.P. \& RAGUENEZ-VIOTTE, G. Cisplatin nephrotoxicity. Toxicol. Lett., v.46, p. $163-175,1989$.

FLOHE, L. The selenoprotein glutathione peroxidase. In: Dolphin, D; Polson, R; Avramovic, O. Glutathione: chemical biochemical and medical aspects., WileyInterscience, Part A, p.643-731, 1989.

FRANKE, K.W. A new toxicant occurring naturaly in certain samples of plants foodstuffs. I. Results obtained in preliminary feeding trials. J. Nut., v.8, p. 597-608, 1934.

FRICK, G.A. etal. Renal excretion kinetics of high-dose cis-dichlorodiammineplatinum (II) administered with hidration and manitol diuresis. Cancer Treat. Rep., v.63, p.13$16,1979$.

GANTHER E. H. Selenitrosulfides. Formation by the reaction of thiols with selenious acid. Biochemistry, v.7, n:8, p.2899-2905, 1968. 
GANTHER, H.E. et al. Selenium: relation to decrease toxicity of methylmercury added to diet containing tuna. Science, v.175, p.1122-1124, 1972.

GEMBA, M. et al. Effect of cisplatin in calcium uptake by rat kidney cortical mitochondria. Toxicol. Lett., v.38, p.291-297, 1987.

GÉRARD-MONNIER, D.; CHAUDIERE, J. Métabolisme et fonction antioxydante du glutathion. Path. Biol., v.44, p.77-85, 1996.

GHYSELINCK, N.B. et al. Structure organization and regulation of the gene for the androgen-dependent glutathione peroxidase like protein specific to the mouse epididymis. Mol. endocrinol., v.7, p.258-272, 1993.

GIBEY, $\mathrm{R}$ et al. Néphrotoxicité de l'association ciclosporine-aminoside chez le rat. $\underline{\text { Path. }}$ Biol., v.38, n. 5bis, p. 513-516, 1990

GIEBISCH, G. \& WINDHAGER, E.E. Eletrolyte transport across renal tubular membranes, In: Handbook of physiology, section 8: Renal physiology (J. Orloff, and R.W.Berliner, eds.). American Physiological Society, Washington, DC, p.135, 1973.

GIMURRAY, S.A new approach to enzyme histochemical analysis of biopsy specimens. J.Clin.Pathol.,v. 42, p. 767-71, 1989.

GISLAIN, C. et al. Course of blood creatinine during repeated injections of cisplatin influence of drug combinations. Therapie, v.45, p.423-427, 1990. 
GIRELLI, D. et al. Low platelet glutathione peroxidase activity and serum selenium concetration in patients with chronic renal failure: relations to dialysis treatments, diet and cardiovascular complications. Clin. Sci., v 84, p. 611-617, 1993.

GOLDSTEIN, R.S. \& MAYOR, G.H. The nephrotoxicity of cisplatin. Life Sci., v.32, p.685-690, 1983.

GONICK, H.C. et al. Urinary $\beta$-Glucoromidase activity in renal disease. Arch. Int. Med., v.132, p.63-69, 1973.

GONZALES-VITALE, J.C. et al. The renal pathology in clinical trials of cis-platinum (II) diamminedichloride. Cancer, v.39, p.1362-1371, 1977.

GORDON, J.A. et al. Water metabolism after cisplatin in the rat. Am. J Physiol., v.243, p. F36-F43, 1982.

GORDON, J.A. \& GATTONE, V.H. Mitochondrial alterations in cisplatin-induced acute renal failure. Am. J. Physiol., v.250, p.F991-F998, 1986.

GORMLEY, P.E. et al.. Kinetics of cis-dichlorodiammineplatinum. Clin. Pharmacol. Ther., v. 25, n.3, p. 351-357, 1979.

GROSS, J. \& PITT-RIVERS, R. The identification of 3, 3',5'-triiodothyronine in humam plasma. Lancet, v.1, p.439-441, 1952. 
GUARINO, A.M. et al. Platinate toxicity: past, present and prospects. Cancer Treat. Rep., v.63, p.1474-1482, 1985.

HAMILTON, C.R. et al. The late effect of cis-pltinum on renal function. Eur. J. Cancer Clin. Oncol., v.25, p. 185-189, 1989.

HARAGSIM, L. \& ZIMA, T. Protective effects of verapamil on cis-plaplatinum and carboplatinum nephrotoxicity in dehydrated and normohydrated rats. Biochem. intern., v.28, p.273-276, 1992.

HARTREE, E. Determination of protein: A modification of lory method that gives a linear photometric response. Anal. Biochem., v.48, p.422-427, 1972.

HAYES, D.M. et al. High dose of cis-platinum diammine chloride. Cancer, v.39, p.1372$1381,1977$.

HEIDEMANN, H.T. et al. Long term effects of acetazolamide and sodium chloride loading on cisplatin nephrotoxicity in the rat. Eur. J. Clin. Invest., v.20, p.214-218, 1990.

HENRY, R.J. et al. Clinical Chemistry, Principles and Techincs, 2nd ed. New York, Harper \& Row, 1974.

HIGBY, D.J. et al. Cisdiamminedichloroplatinum (NSC-1 19875): a phase I study. Cancer Chemother Rep, v. 57, p.459-463, 1973. 
HILL, J. et al. Clinical experiences with cisplatinous diamminodichloride (DDP). In : Advances in antimicrobial and antineoplastic chemoterapy, vol.II. Baltimore, University Park Press, p.255, 1972.

HILL, K.E.et al. The cDNA for rat selenoprotein P contains 10TGA codons in the open reading frame. J Biol. Chem., v.266, p. 10050-10053, 1991.

HOLDENER, E.E.et al. Effect of mannitol and plasma on the cytotoxicity of cisplatin. Eur. J. Cancer Clin. Oncol., v. 19, p.515-518, 1983.

HORAK, E. et al. Spectrophotometric assay for urinary $N$-acetyl- $\beta$-D-glucosaminidase activity Clin. Chem., Baltimore, v.27, n.7, p.1180-1185, 1981.

HULTBERG, B. , RAVNSKOV, U. The excretion of $N$-acetyl- $\beta$-D-glucosaminidase in glomerulonephritis Clin. Nephrol., v.15, n.1, p.33-38, 1981.

HUTCHISON, F.N. et al. Renal salt wasting in patients treated with cisplatin. Ann. Intern. Med., v.108, p.21-25, 1988.

ICHIKAWA, I. et al. Renal antioxidant enzymes: their regulation and function. Kidney Int., v.45, n.1, p.1-9, . 1994.

ISHIKAWA, T. \& ALI-OSMAN, F. Glutathione-associated cisdiamminedichloroplatinun (II) metabolism and ATP-dependent effux from leukemia cells. J. Biol. Chem., v. 268, n.27, p. 20116-20125, 1993. 
IÇLY, F. et al. Several vascular toxicity associated with cisplatin-based chemotherapy. Cancer, v.72, n.2, p.587-589, 1993.

JACOBS, C. et al. Renal handling of cis-diamminedichloroplatinum (II). Cancer Treat. Rep., v.64, p.1223-1226, 1980.

JAESCHKE, H. Mechanism of oxidant stress-induced acut tissue injury. Proc. Soc. Exp. Biol. Med., v.209, p.104-111, 1995.

JOHN, P.W.M. Statistical design and analysis of experiments. The Macmillan Company, New York, 1971.

JONES, B.R. et al. Comparison of methods of evaluating nephrotoxicity of cis-platinum. Clin. Pharmacol. Ther., v. 27, n. 4, p. 557-562, 1980.

JONES, T.W.. et al. Cis-diamminedichloroplatinum (II) - induced acute renal failure in the rat. Correlation of structural and functional alterations.J. Lab. Invest., v.52, p.363-374, 1985.

JUNG, Klaus. Enzymes activies in urine: How should we express their excretion? Eur. J. Clin. Chem. Clin. Biochem., v. 29, n.11, p.725-729, 1991 a.

JUNG, $K$ et al. Methods compared for determinating activity of N-acetil-B-Dglucosaminidase in urine without pretreatement of sample: different sensitivity and species effect. Enzimes, v.45, n.4, p.215-21, 1991 b. 
KAR, A.B. et al. Prevention of cadmium induced changes in the gonads of rats by zinc and selenium - a study in antagonism between metals in the biological system. Proc. Nat. Inst. Sci. India, v. 26parte B, p. 40-50, 1960.

KOMIYA, K. et al. Studies on protective effect of mercurial toxicity by selenium. I: Relationship between protective effects of various selenium compounds on the toxicity of mercuric chloride and distributions of mercury and selenium in rats tissues. Eisei Kagaku, v.23, p.235-243, 1977.

KOVACH, J.J. et al. Phase II study of cis-platinum (NSC_119875) in advanced carcinoma of the large bowel. Cancer Chemother Rep., v.57, p.357-359, 1973.

LAKATUA, D et al. Circadian rhythm in urinary $\mathrm{N}$-acetil- $\beta$-glucosaminidase (NAG) of clinically healthy subjects. Am. J. Clin. Pathol., v.78, n.1, p.69-77,1982

LANG, F. et al. Proteins, the liver and the kidney - hepatic regulation of renal function. Nephron, v. 61, p. 1-4, 1992.

LASH, L.H. Intracellulardistribuition of thiols and disulfides: assay of mitochondrial glutathione transport. Method. Enzimol., v.252, p.14-26, 1995

LEIBBRANDT, M.E.I. \& WOLFGANG, G.H.I. Differential toxicity of cisplatin, carboplatin, and CI-973 correlates with cellular platinum levels in rat renal cortical slices. Toxicol. Appl. Pharmacol., v.132, p.245-252, 1995. 
LEMOS, E. de et al. Variations circadiennes de la néphrotoxicité de l'association vancomycine-gentamicine chez le rat. Path. Biol., v. 39, n. 1, p. 12-15, 1991.

LEONARD, J.L. \& VISSER, T.J. Biochemistry of deiodination of thiroyd hormone metabolism. Hennemann, G., ed. Marcel Dekker, p. 189-229, 1986.

LEVI, J. et al. Mechanism of cis-platinun nephrotoxicity: I Effects of sulphydryl groups in rat kidneys. J. Pharmacol. Exp. Ther., v.213, n.3, p.545-550, 1980.

LI, Q. et al. The protective effect of glycine in cisplatin nephrotoxicity: inhibition with

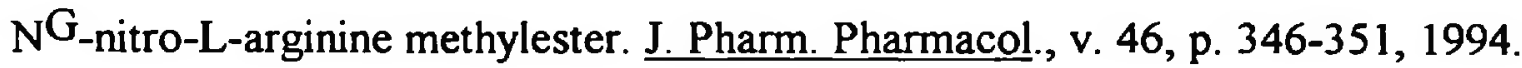

LI, Q. et al. Amelioration of cisplatin nephrotoxicity with glycine: dose dependency in rats. J. Pharm. Pharmacol., v.47, p.223-226, 1995.

LIN, L. et al. Temporal changes of pharmacokinetics, nephrotoxicity, and subcellular distribuition of tobramicin in rats. Antimicrob. Agents Chemother., v. 38, p. 54-60, 1994.

LINDH, U. et al. Selenium protection against toxicity from cadmium and mercury studied at the cellular level. Cell. Mol. Biol., v.42, p.39-48, 1996.

LIPPARD,S.J. Chemistry and molecular biology of cisplatinun anticancer drugs. Pure \& Appl. Chem, v.59, n.6, p.731-742, 1987. 
LITTERST, C.L Alterations in the toxicity of cis-dichlorodiammineplatinum-II and in tissue localization of platinum as a function of $\mathrm{NaCl}$ concentration in the vehicle of administration. Toxicol. Appl. Pharmacol., v.61, p.99-108, 1981.

LITTERST, C.L et al. Sensitivity of urinary enzimes as a indicator of renal toxicity of anticancer drug cis-platin. Uremia Invest., v.9, p.111-117, 1985.

LITTERST, C.L. \& WEIS, R.B. Clinical and experimental nephrotoxicity of cancer chemotherapeutic agents. In: Nephrotoxicity in the experimental and clinical situation (P.H. Back and E.A. Lock eds.), Martinus Nijhoff, Dordrecht, M.A., p.771-816, 1987.

LIU, P.T et al. Studies in sirurgical trauma: oxidative stress in isquemia-reperfusion of rat liver. Clin. Sci., v.85, n.3, p.453-60, 1994.

LOEHRER, P.J. \& EINHORN, L.H.. Cisplatin. Ann. Int. Med., v. 100, p. 704-713, 1984.

MADIAS, N.E. \& HARRINGTON, T. Platinum nephrotoxicity. Am. J. Med., v.65, p.307-314. 1978.

MAIORINO, M. et al. reactivity of phospholipid hgydroperoxide glutathione peroxidase with membrane and lipoprotein lipid hydroperoxides. Free Rad. Res. Comms., v.13, p.131-135, 1991. 
MANDEL, L.J. Primary active sodium transport, oxygen consumption and ATP. Coupling and regulation. Kidney Int., v.29, p.3-9, 1986.

MANICCIA-BOZZO, E. et al. Differential effects of cisplatin on mouse hepatic and renal mitochondrial DNA. Mol. Cell Biochem., v.94, p.83-88,1990.

MASON, R. W., EDWARDS, I. R. Cisplatin-induced alteration of the copper and zinc content of the rat kidney. Biochemical Pharmacol., v.34, n.14, p.2575-2577, 1985a.

MASON, R.W., EDWARDS, I. R. Studies on the copper and zinc content of the rat kidney after treatment with cisplatin. Toxicology, v.37, n.3-4, p.267-274, 1985b.

MAVICHAK, $\mathrm{V}$ et al.. Studies on the pathogenesis of cisplatin-induced hypomagnesemia in the rats. Kidney Int., v.28, n.6, p.914-921, 1985.

MEIJER, S. et al. Some effects of combination chemotherapy with cis-platinun on renal function in pactients with non seminomatous testicular carcinoma.Cancer, v.51, p.2035-2040, 1983.

MELICHAR, B. et al. Association between renal tubular dysfunction and increased urinary zinc excretion in cancer patients. Scand. J. Clin. Lab. Invest., v. 55, p. 149$152,1995$.

MIURA, $\mathrm{K}$ et al. Cisplatin nephrotoxicity: Role of filtration and tubular transport of cisplatin in isplated perfused kidneys. Toxicology v.44, p.147-158, 1987. 
MULLENBACH, G. T. et al. Selenocisteyne's mechanism of incorporation and evolution revelkead in cDNAs of three glutathione peroxidases. Protein. Eng., v. 2, p. $239-246,1988$.

NAGAI, N. et al. Effects of sodium thiosulfate on the pharmacokinetics of unchanged cisplatin and on the distribuition of platinum species in rat kidney: protective mechanism against cisplatin nephrotoxicity. Cancer Chemother. Pharmacol. , v.36, p.404-410, 1995.

NAGANUMA, A. et al. Selenium efficiently depressed toxic side effect of cisdiamminedichloroplatinum. Res. Comm. Chem. Pathol Pharmacol., v.42, p. 127-134, 1983.

NECHAY, B.R. \& NELDON, S.L. Characteristics of inhibition of human renal adenosine triphosphatases by cisplatin and chloroplatinic acid. Cancer Treat. Rep., v.68, p.1135-1141, 1984.

NELSON, A.A. et al. Liver tumors following cirrhosis caused by selenium in rats. Cancer Res., v.3, p.230-236, 1943.

OFFERMAN, J.J.G. et al. Acute effect of cisdiamminediclhoroplatinum (CDDP) on renal function. Cancer Chemother. Pharmacol., v.12, p.36-38, 1984. 
OHKAWA, K. et al. The effects of co-administration of selenium and cis-platin (CDDP) on CDDP-induced toxicity and antitumour activity. Br. J. Cancer, v. 58, p. $38-41$, 1988 .

OLIVIERI, O.et al. Low selenium status in the elderly influencis thyroid hormones. Clinical Science, vol. 89, p. 637-642, 1995.

OLIVERO, O.A. et al. Preferencial biding of cisplatin to mitochondrial DNA of chinese hamster ovary cells. Mutation Res., v.346, p.221-230, 1995.

OSMAN, N.M. et al. Amelioration of cisplatin-induced nephrotoxicity by diuretic acetazolamide in F344 rats. Cancer Treat. Rep., v.68, p.999-1004, 1984.

OZOLS, R.F. et al. High-dose cisplatin in hypertonic saline. Ann. Intern. Med., v.100, p.19-24, 1984.

PAINTER, E. P. The chemistry and toxicity of selenium compounds with special reference to the selenium problem. Chemical Reviews, v. 28, p. 179-213, 1941.

PARIZEK, J. \& OSTADALOVA, I. The protective effect of small amounts of selenium in sublimate intoxication. Experimentia, v.23, p.142-144, 1967.

PERA, M.F. et al. Effects of mannitol or furosemide diuresis on the nephrotoxicity and physiological disposition of cis-dichlorodiammineplatinum (II) in rats. Cancer Res., v.39, p.1269-1278, 1979. 
PERA, M.F. \& HARDER, H.C. Effects of mannitol or furosemide diuresis on cisdichlorodiammineplatinum (II) antitumour activity and toxicity to host- renewing cell populations in rats. Cancer Res., v.39, p.1279-1286, 1979.

PEREZ, R.P et al. Comparative citotoxicity of CI-973, cisplatin, carboplatin and tetraplatin in human ovarian carcinoma cells lines. Int. J. Cancer, v.48, n.2, p.265$269,1991$.

PETERSON, P.A. et al. Differentiation of glomerular, tubular and normal proteinuria: determinations of urinary excretion of beta-2-microglobulina, albumina and total protein. J. Clin. Invest., v. 48, p. 1189-1198, 1969.

PHELPS, J.P. et al. Cisplatin nephrotoxicity: In vitro studies with precision-cut rabbit renal cortical slices. Toxicol. Appl. Pharmacol., v.90, p. 501-512, 1987.

PRICE, R.G. The role of NAG (N-acetil- $\beta-D$-glucosaminidase) in the diagnosis of kidney disease including the monitoring of nephrotoxicity. Clin. Nephrol., v.38, Suppl.n.1, p.S14-S18, 1992.

REEVES, N.C. et al. AIN-93 purified diets for laboratory rodents: final reports of the americam institute of nutrition ad hoc writing commitee on the reformulation of the AIN-76 rodent diet. J. Nut., v.123, p.1939-1951, 1993.

ROSENBERG, B. et al.. Inhibition of cell division in Escherichia coli by eletrolysis products from platinum eletrode. Nature, v.205, p. 698-699, 1965. 
ROSENBERG, B. et al..The inhibition of growth or cell division in Escherichia coli by different ionic species of platinum (IV) complexes. J. Biol. Chem., v.242, n.6, p. 1347-1352, 1967.

ROSENBERG, B. et al.. Platinum compounds: a new class of potent antitumour agents. Nature, v. 222, p. 385-386, 1969.

ROSENBERG, B.. Fundamental studies with cisplatin. Cancer, v.55, p.2303-2316, 1985.

ROZENCWEIG, G.M. et al.. cis-diamminedichloroplatinum (II). Ann. Int. Med., v.86, p.803-812, 1977.

ROTRUCK, J. T. et al. Selenium: Biochemical role as a component of glutathione peroxidase. Science, v. 179, p. 558-590, 1973.

SADZUKA, Y et al. Effects of cisplatina on the activities of enzymes wich protect against lipid peroxidation Biochem. Pharmacol., v.43, n.8, p. 1872-1875, 1992.

SAFIRSTEIN, R. et al. Cisplatin nephrotoxicity in rats: defect in papillary hypertonicity. Am. J. Physiol., v. 241, p. F175-F185, 1981.

SAFIRSTEIN, R. et al. Uptake and metabolism of cisplatin by rat kidney . Kidney Inetr., v. 25, p. $753-758,1984$. 
SALAZAR, I. et al. The effect of benzo[a]pyrene on DNA synthesis and DNA polymerase activity of rat liver mitochondria, FEBS Lett., v.138, p.43-49, 1982.

SANCHEZ-BERNAL, $C$. et al. Variation in the isoenzimes of N-acetil- $\beta$-Dglucosaminase and protein excretion in aminoglycoside nephrotoxicity in the rat. Cell Biochem Function, v.9, p.209-214, 1991.

SCHILSKY, R.L. \& ANDERSON, T. Hypomagnesemia and renal magnesium wasting in patients receiving cisplatin. Ann. Intern. Med., v.90, p.929-931, 1979.

SCHWARZ, $\mathrm{K}$ et al., Selenium as an integral part of factor 3 against dietary liver degeneration. J. American Chem. Society, v. 79, p. 3292-3293, 1957.

SEDLAK, M. \& LINDSAY, R. Estimation of total, protein-bound and non-protein sulphydriyl groups in tissue with Ellman's reagent. Anal. Biochm., v.25, p.192-205, 1968.

SEGURO, A.C. et al. Renal concentration induced by cisplatin. Am. J. Nephrol., v.9, p.59-65, 1989.

SEIFTER, J. et al. Thyroid adenomas in rats receiving selenium. Science, v.103, p.762$766,1946$. 
SEKO, $\mathrm{Y}$ et al Active oxygen generation by the reaction of selenite with reduced glutathione in vitro. In: Wendel, A., ed. Selenium in Biology and medicine. Berlin: Springer-Verlag, , p.70-73, 1989.

SHAMBERGER, R.J. \& RUDOLPH, G. Protection against carcinogenesis by antioxidants. Experimentia, v.22, p.116-121, 1966.

SHAN, X. et al. Glutathione-dependent protection against oxidative injury. Pharmacol. Ther., v. 47, p. 61-77, 1990.

SHAPIRO, J.R. Selenium and carcinogenesis: a review. Ann. N.Y. Acad. Sci., v.192, p.215-219, 1972.

SHARMA, R.P. \& EDWARDS, I.R. Cisplatinum: subcellular distribuition and biding to cytosolic legands. Biochem. Pharmacol., v.32, p.2665-2669, 1983.

SHILS, M.E. Experimental humam magnesium depletion. Medicine, v.48, p.61-85, 1969.

SHNERMANN, J. Microperfusion study of single short loops of Henle in rat kidney. Pflugers Arch., v:300, p.255-282, 1968.

SIDDIK, Z.H. et al. Renal pharmacokinetics and toxicity of cisplatin and carboplatin in animals, in Biochemical mecanisms of platinum antitumor drugs (D.C.H. McBrien and T.F.Slater, eds.), IRL, Oxford. p-171-186, 1986. 
SIDDIK, Z.H. et al.. The comparative pharmacokinetics of carboplatin and cisplatin in mice and rats. Biochem. Pharmacol., v. 36, n. 12, p. 1925-1932, 1987.

SILVA, P. Renal fuel utilization, energy requirements and function. Kidney Int., v.32, p.S9-S14, 1987.

SINGH, G. Cisplatin-induced nephrotoxicity. Can. Fed. Biol. Soc., v.29, p.136, 1986.

SINGH, G. A possible celular mechanism of cisplatin-induced nephrotoxicity. Toxicology, v.58, n.1, p.71-80, 1989.

SNEDECOR, G.W. \& COCHRAN, W.G. Statistical Methods. The Iowa State University Press, 1963.

SOLTOFF, S.P. ATP and the regulationof renal cell function. Annu. Rev. Physiol., v.48, p.9-31, 1986.

SPALLHOLZ, J.E. On the nature of selenium toxicity and carcinocist activity. Free Rad.Res Biol. \& Med., v. 17, n :1, p. 45-64, 1994.

SUGIHARA, $\mathrm{K}$. et al. Effects of cisplatin on in vitro production of lipid peroxides in rat kidney cortex. Japan. J. Pharmacol., v. 44, p. 71-76, 1987. 
SUGIYAMA, S. et al. Adverse effects of anti-tumor drug, cisplatin, on rat kidney mitochondria: disturbances in glutathione peroxidase activity. Biochemical Biophysical Res. Comm., v. 159, n.3, p.1121-1127, 1989.

THIEL, G. et al. Protection of rat kidney against $\mathrm{HgCl}_{2}$ - induced acute renal failure by induction of high urine flow without renin supression. Kidney Int., v. 10, p.1991-198, 1976.

THURAU, K. \& BOYLAN, J.W. Acute renal success: the unexpected logic of oliguria in acute renal failure. Am. J. Med., v.61, p.308-315, 1976.

TIRELLI, A.S. et al. Follow up study of enzymuria and $\beta 2$-microglobulina during cisplatinum treatment. Eur. J. Clin. Pharmacol., v.29, p.313-318, 1985.

TISHER, C.A. Anatomy of the kidney, in The Kidney (Brenner and Rector, eds.), W.B.Saunders Co., Philadephiia, p.28-35,1981.

TOGNELLA, T. Pharmacological interventions to reduce platinum-induced toxicity. Cancer Treat. Rev., v. 17, p.139-142, 1990.

TORII, Y. et al. Involvment of free radicals in cisplatin-induced emesis in Suncus murinus. Eur. J. Pharmacol., v.248, n.2, p.131-135, 1993. 
TUCKER, Susan M., PIERCE, Raymond J., PRICE, Robert G. Characterisation of human $\mathrm{N}$-acetyl- $\beta$-D-glucosaminidase isoenzymes as an indicator of tissue damage in disease. Clin. Chim. Acta, v.102, p.29-40, 1980.

TUXEN, M.K. \& HANSEN, S.W. Neurotoxicity secondary to antineoplastic drugs. Cancer Treat. Rev.v.20, p.191-214, 1994.

UCHIYAMA, M. \& MIHARA, M. Determination of malonaldehyde precursor in tissues by thiobarbituric acid test. Analyt. Biochem., v.86, n.1, p.271-278, 1978.

UOZOMI, U. \& LITTEREST, C.L. The effect of cisplatin on renal ATPase activity in vivo and in vitro. Cancer Chemother. Pharmacol.., v.15, p.93-96, 1985.

URSINI, F. et al. The selenoenzyme phospholipid hydroperoxide glutathione peroxidase. Biochem Biophys Acta, vol. 839, p. 62-70, 1985.

VAIL, D.M. et al.. Methimazole as a protectant against cisplatin-induced nephrotoxicity using the dog as a model. Cancer Chemoter. Pharmacol., v. 33, p. 25-30, 1993.

VADHANAVIKIT, S. \& GANTHER, H. E.. Selenium requeriments of rats for normal hepatic and thyroidal 5'-deiodinase (type I) activities. J. Nutr, v.123., p. 1124-1128, 1993.

VENDELAND, S. C. et al. Intestinal absorption of selenite, selenate, and selenothionine in the rat. J. Nutr. Biochem., v.3, p. 359-365, 1992. 
VERMEULEN, N.P.E. \& BALDEW, G.S. The role of lipid peroxidation in the nephrotoxicity of cisplatin. Biochem. Pharmacol., v.44, n.6, p.1193-1199, 1992.

VERMEULEN, N.P.E et al. Reduction of cisplatin nephrotoxicity by sodium selenite. Drug Metab. Disp., v.21, p.30-36, 1993.

VERMOKEN, J.B. Cis-diamminedichloroplatinum (II) (cisplaton) clinical pharmacological studies. Amsterdan, 1986. 175p. Tese (Doutorado) Free University Press.

VERNIE, L. N. Selenium in carcinogenesis. Biochem Biophys Acta, v.738, p. 203-217, 1984.

VOGELZANG, N.J. et al. Hypomagnesemia, renal dysfunction, and Raynaud's phenomenon in patients treated with cisplatin, vinblastine, and bleomycin. $\underline{\text { Cancer}}$, v.56, p.2765-2770, 1985.

WALLACE, H.J. \& HIGBY, D.J. Phase I evolution of cis-diamminedichloroplatinum and a combination of DDP plus adriamycin. In: Connors, T.A., Roberts, J.J., eds. Platinum-coordination complexes in cancer chemoterapy. Heidelberg. Spring-Verlag, p.167, 1974.

WIKTOROWICZ, J. et al. urification and properties of human kidney-cortex hesoxaminidases A and B. Biochem. J., v.165, n.1, p.49-53, 1977. 
WILTSHAW, E. \& CARR, B. Cis-platinumdiamminedichloride. In: Connors, T.A., Roberts, J.J., eds. Platinum-coordination complexes in cancer chemoterapy. Heidelberg. Spring-Verlag, p.178, 1974.

WINKLER, A.W. \& PARRA, J. Mesusement of glomerular filtration. Creatinine, sucrose, and urea clearances in subjects without renal disease. J. Clin. Invest., v.16, p.869-877, 1937.

WINSTON, J.A. \& SAFIRSTEIN, R. Reduced renal blood flow in early cisplatininduced acute renal failure in the rat. Am. J. Physiol., v.249, p.F490-F496, 1985.

WOLF, W. \& MANAKA, R.C. Synthesis and distribuition of $195 \mathrm{~m}$ Ptcisdichlorodiammineplatinum (II). J. Clin. Hematol. Oncol., v.7, p.79-84, 1977.

WOLPERT- DeFILIPPES, M.K.. Antitumor activity of cis-diamminedichloroplatinum (II). Cancer Treat. Rep., v.63, p. 1453-1457, 1979.

ZHANG, J-G. \& LINDUP, W. E.. Role of mithocondria in cisplatin-induced oxidative damage exhibited by rat renal cortical slices. Biochem. Pharmacol, v.45, n.11, p.2215-2222, 1993.

ZHANG, J-G et al. Comparision of the toxicities of cisplatin and a new cisplatin-procaine complex to rat renal cortical slices. Human \&Exp. Toxicol., v. 15, p.59-63, 1996. 
ZHONG, L.F. et al. Protection against cisplatin induced lipid peroxidation and kidney damage by procaine in rats. Arch. Toxicol., v.64, n.7, p.599-600, 1990.

ZWELLING, L.A. \& KOHN, L.W.. Mechanism of action of cis-diammineplatinium (II). Cancer Treat. Rep., v.63, n.9-10, p.1439, 1979. 


\section{SUMMARY}

Cisplatin is an important antineoplastic drug, widely used against ovarian, testis and bladder cancer. Nephrotoxicity has been observed as a dose-limiting factor in cisplatin therapy. The mechanism of cisplatin-induced nephrotoxicity is not know yet and it have been associated with renal lipidic peroxidation. Administration of some substances has been used to protect against the nephrotoxicity. The aim of this study was to determine whether selenium (sodium selenite, by gavage) provide protection against cisplatininduced nephrotoxicity in Wistar rats. Animals were divided in 4 groups $(n=6)$, wich were treated with i.p. injections of cisplatin $5 \mathrm{mg} / \mathrm{kg}$ (Cisplatin and Cisplatin+selenium groups). The influence of selenium on cisplatin nephrotoxicity was studied by oral administration of sodium selenite 24 hours prior to the cisplatin administration. After 7 days of cisplatin administration, the rats were sacrified and the renal levels of lipid peroxidation were evaluated by the method of tiobarbituric acid reactive substances and renal glutathion. The daily level of urinary N-acetyl- $\beta$-Dglucosaminidase total and isoenzyme $B$, urinary volume, total urinary protein, plasmatic creatinine and creatinine clearance were determined to evaluate the nephrotoxicity. We can suggest that lipidic peroxidation may be associated with cisplatin-induced nephrotoxicity mecanism. Oral 
administration of selenium did not provide protection against cisplatininduced nephrotoxicity, due the body weight, kidney weight, plasmatic creatinine, creatinine clearance, and total protein urinary results. However considering urinary volume and $B$ isoenzyme activity results, we can suggest that selenium provides partial protection to early injury cisplatin-induced in proximal tubules. 
APÊNDICE 
TABELA 9: Componentes da ração para roedores Formulação CIZIP (USP)

\begin{tabular}{lc}
\hline Componentes & $\%$ \\
\hline & 52,0 \\
Fubá de milho & 20,1 \\
Farelo de soja & 10,0 \\
Farinha de carne & 7,0 \\
Farelo de trigo & 7,0 \\
Farinha de peixe & 2,0 \\
Caulim & 1,0 \\
Óleo vegetal & 0,5 \\
Sal comum & 0,4 \\
Farinha de osso & 0,15 \\
Mistura mineral e vitaminica & \\
\hline
\end{tabular}


TABELA 10: Composição percentual da ração para roedores

\section{$\%$}

Teor de umidade

11,50

Proteina bruta

23,10

Extrato etéreo

4,45

Matéria fibrosa

3,20

Cálcio

9,85

Matéria mineral

2,14

Fósforo

1,28

Sódio

0,36

Potássio

0,80

E.N.N. (carboidratos)

47,90 
TABELA 11: Enriquecimento por quilograma de ração

\begin{tabular}{lr}
\hline Componente & Concentração \\
\hline Vitamina A & $3000 \mathrm{UI}$ \\
Vitamina B1 & $750 \mathrm{mcg}$ \\
Vitamina B2 & $1260 \mathrm{mcg}$ \\
Vitamina B6 & $750 \mathrm{mcg}$ \\
Vitamina B12 & $2 \mathrm{mcg}$ \\
Vitamina B3 & $555 \mathrm{UI}$ \\
Vitamina E & $6300 \mathrm{mcg}$ \\
Vitamina K3 & $750 \mathrm{mcg}$ \\
Ácido pantotênico & $3750 \mathrm{mcg}$ \\
Ácido fólico & $120 \mathrm{mcg}$ \\
Biotina & $52.5 \mathrm{mcg}$ \\
Colina & $9000 \mathrm{mcg}$ \\
Metionina & $300 \mathrm{mcg}$ \\
Manganês & $12,600 \mathrm{mcg}$ \\
Ferro & $10,050 \mathrm{mg}$ \\
Zinco & $9,000 \mathrm{mg}$ \\
Cobre & $1,500 \mathrm{mg}$ \\
Iodo & $0,105 \mathrm{mg}$ \\
Selênio & $0,040 \mathrm{mg}$ \\
\hline
\end{tabular}




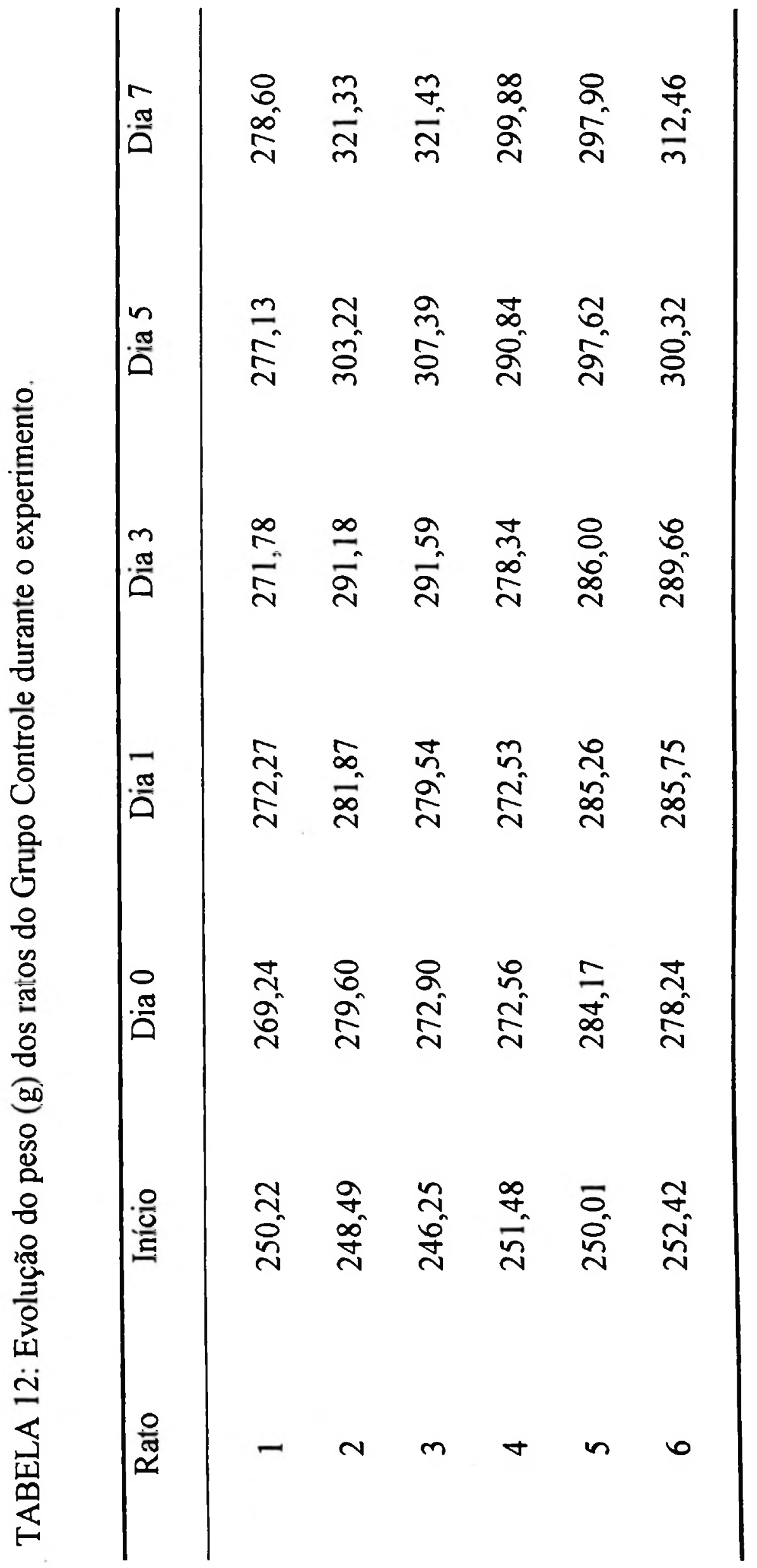




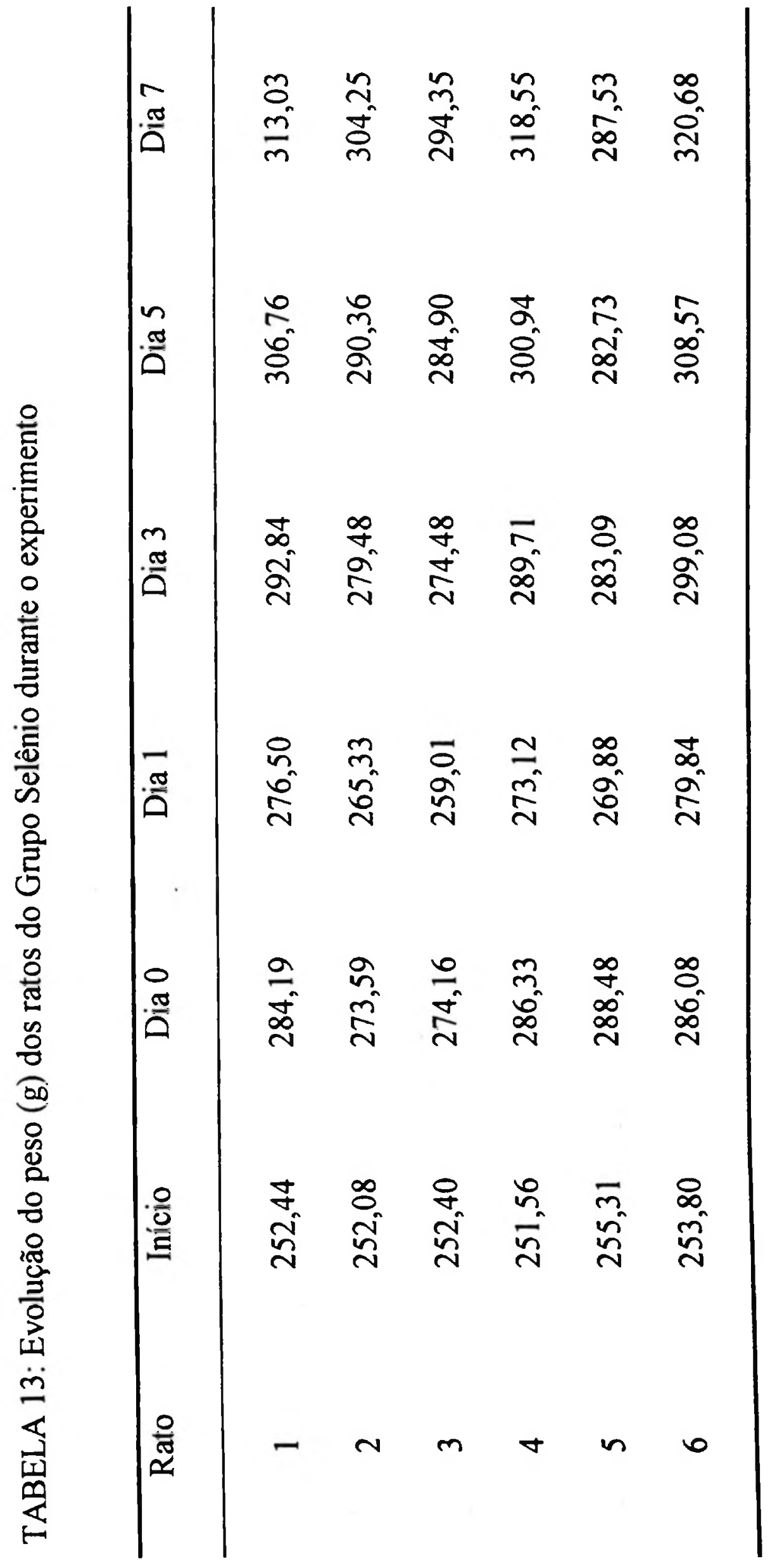




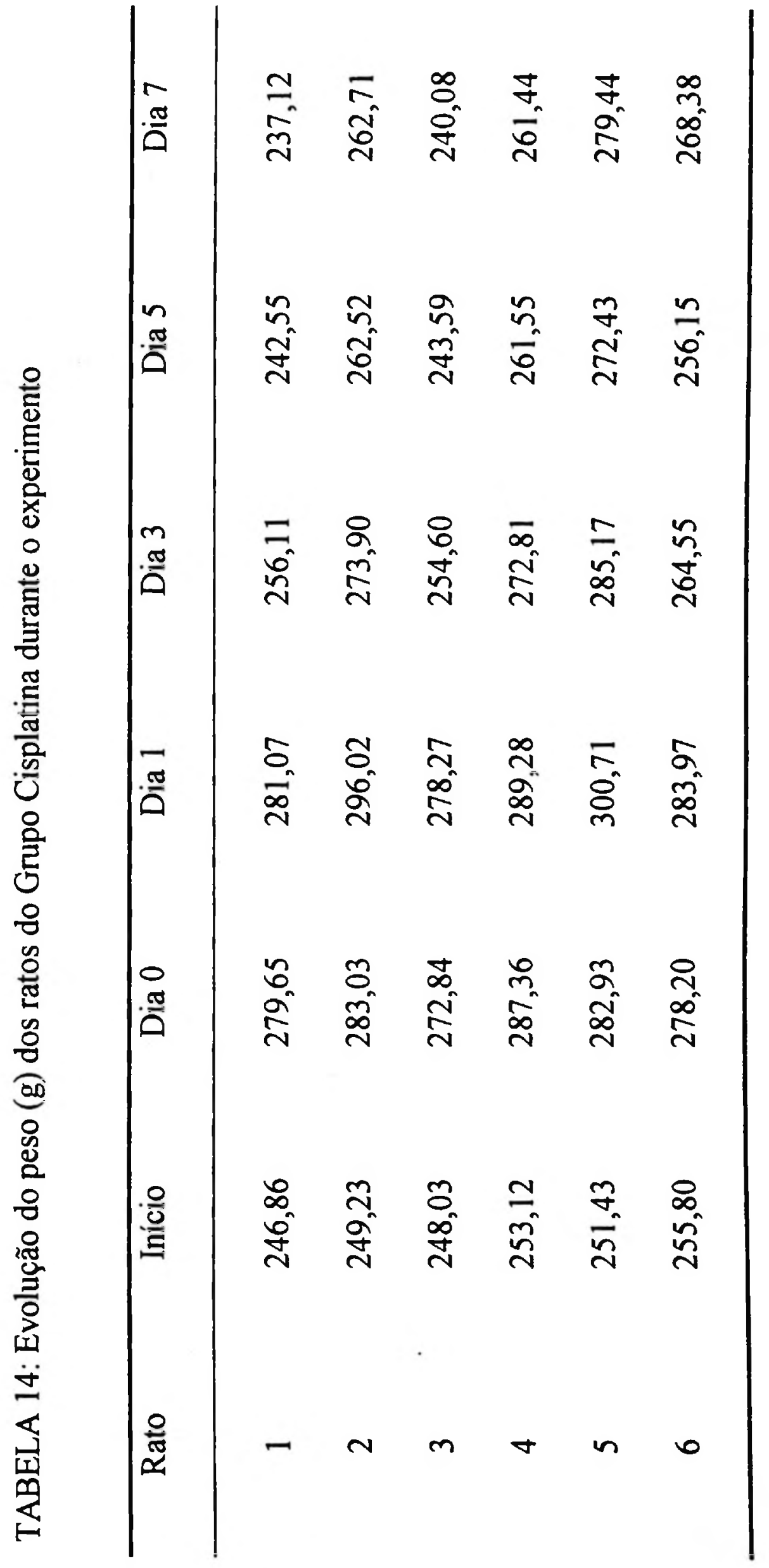




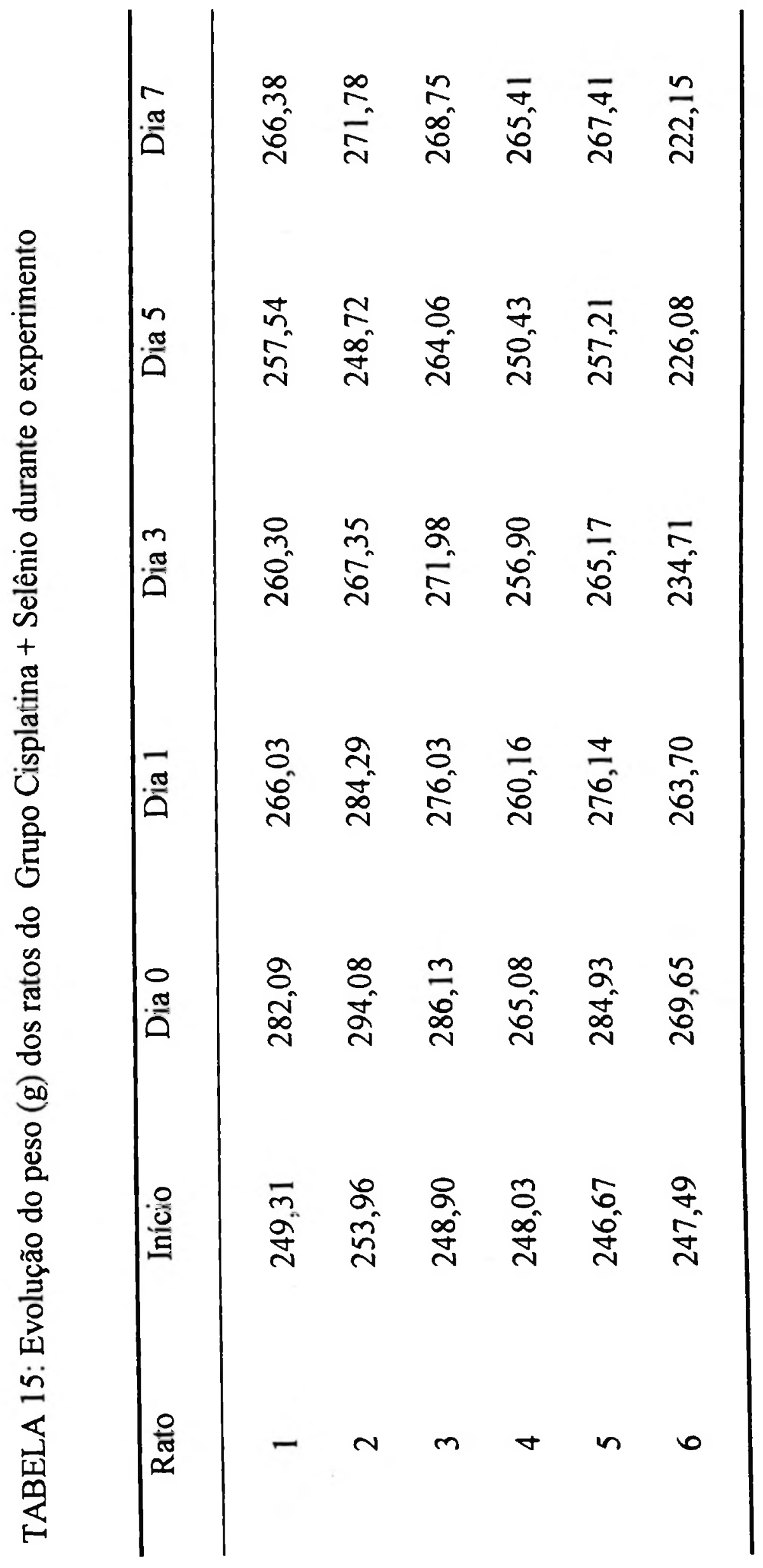




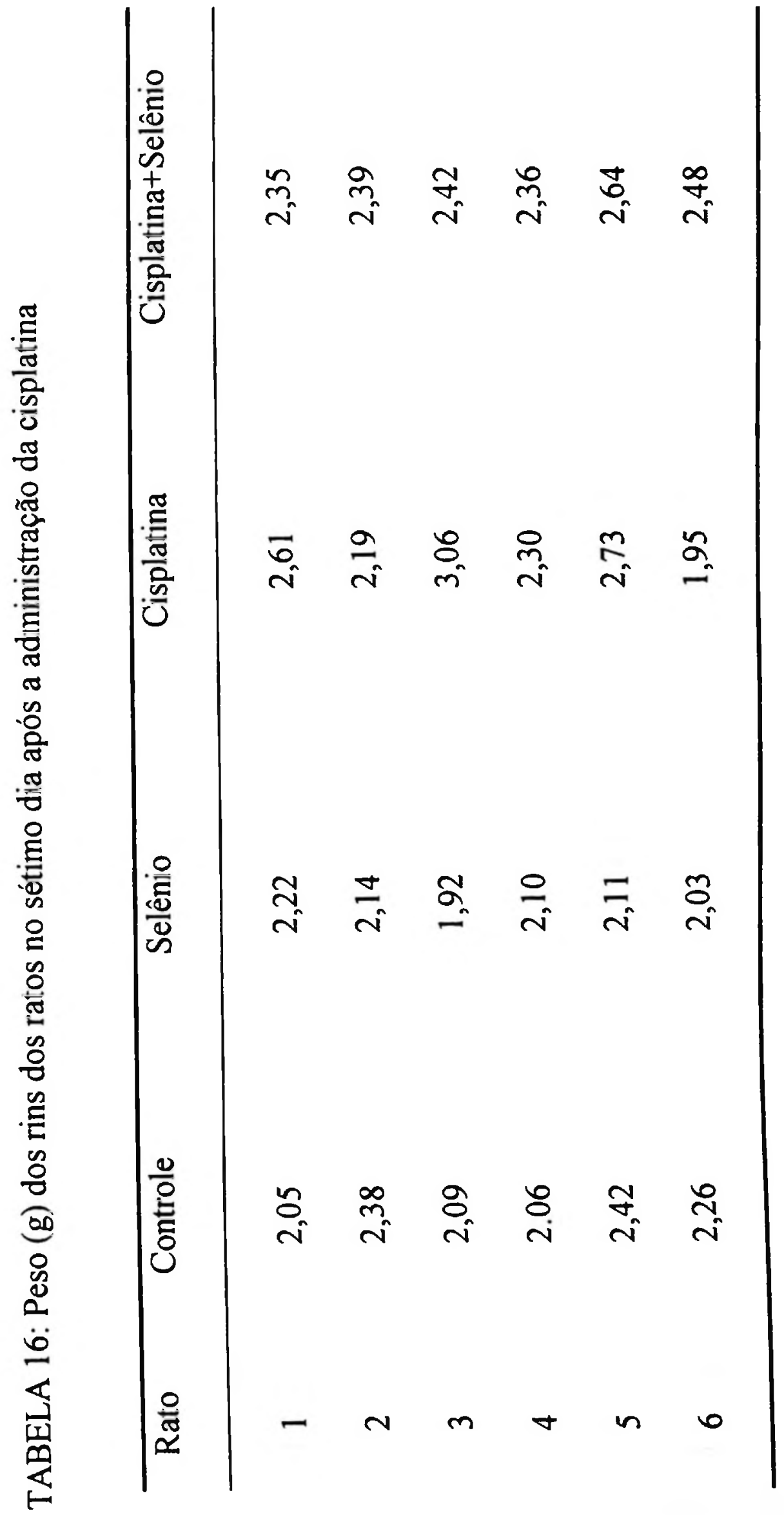




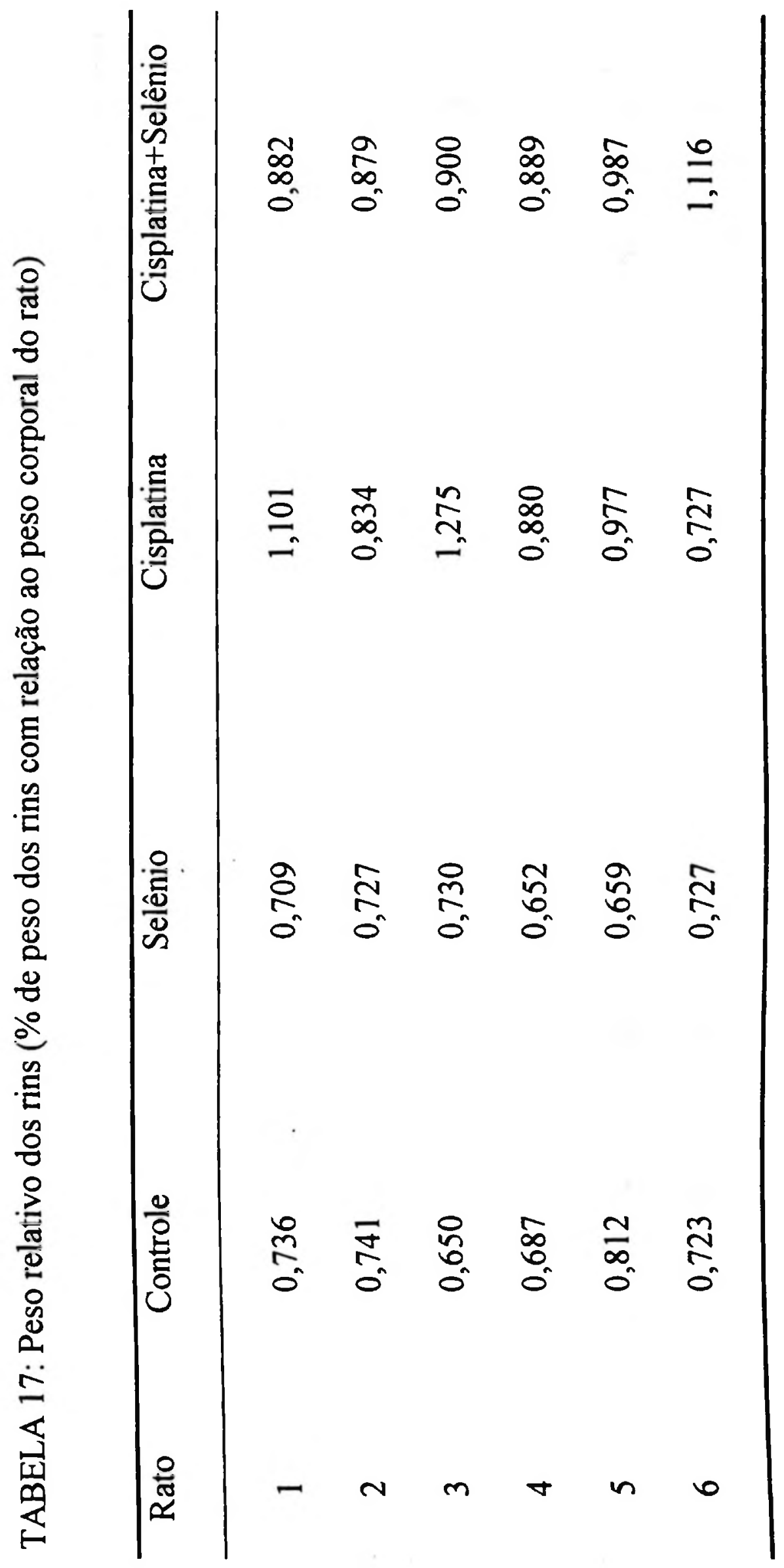




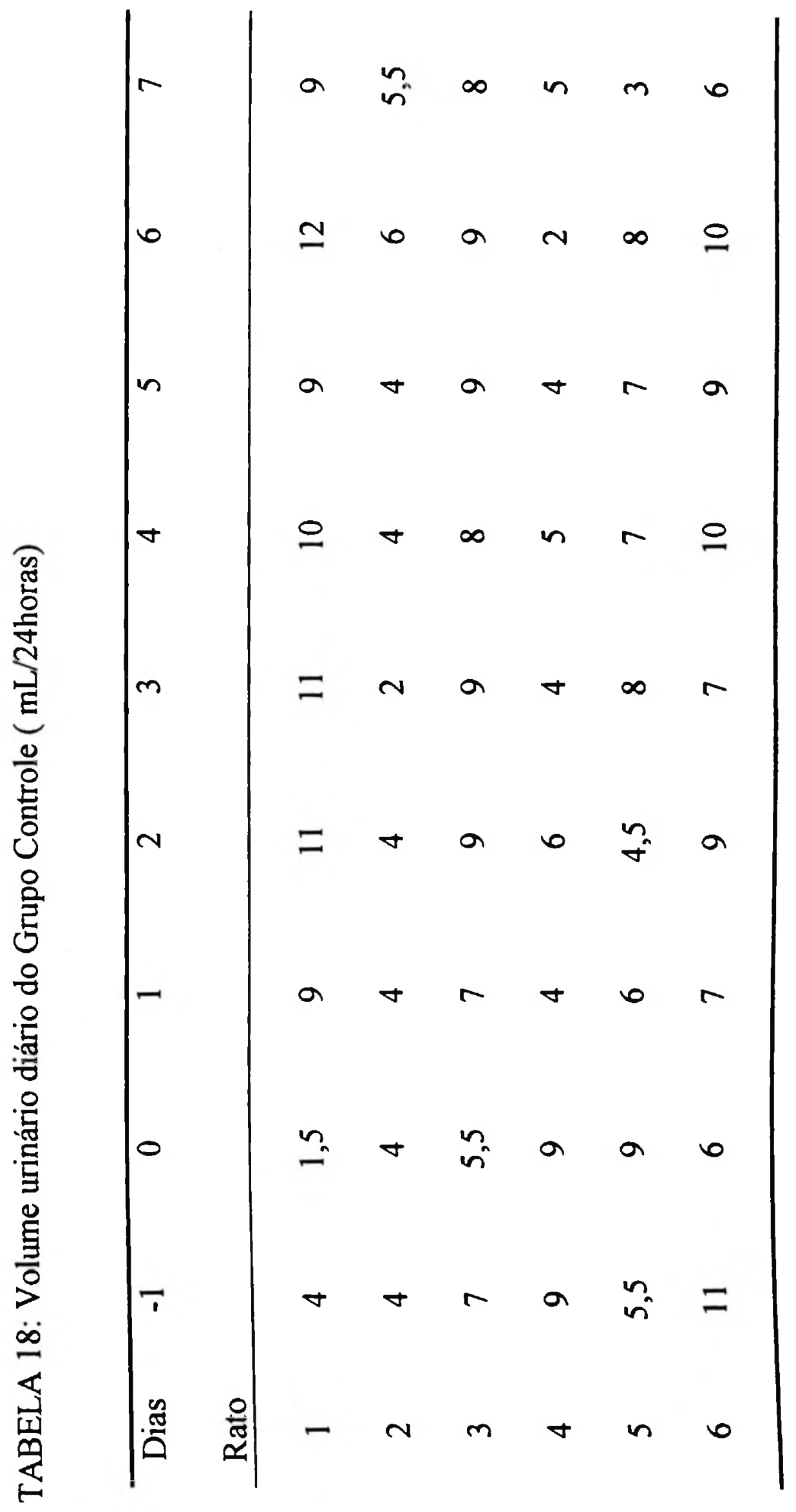





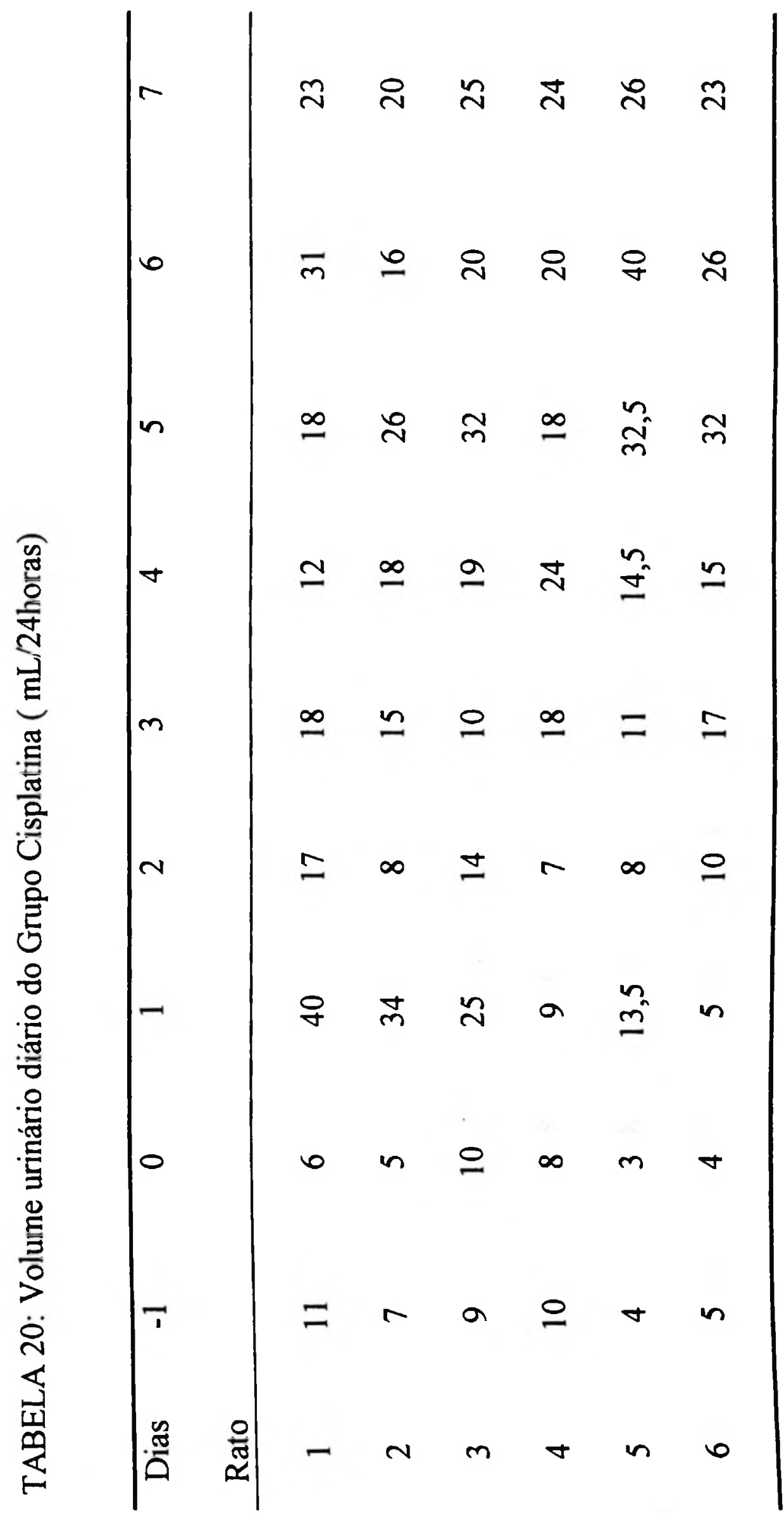




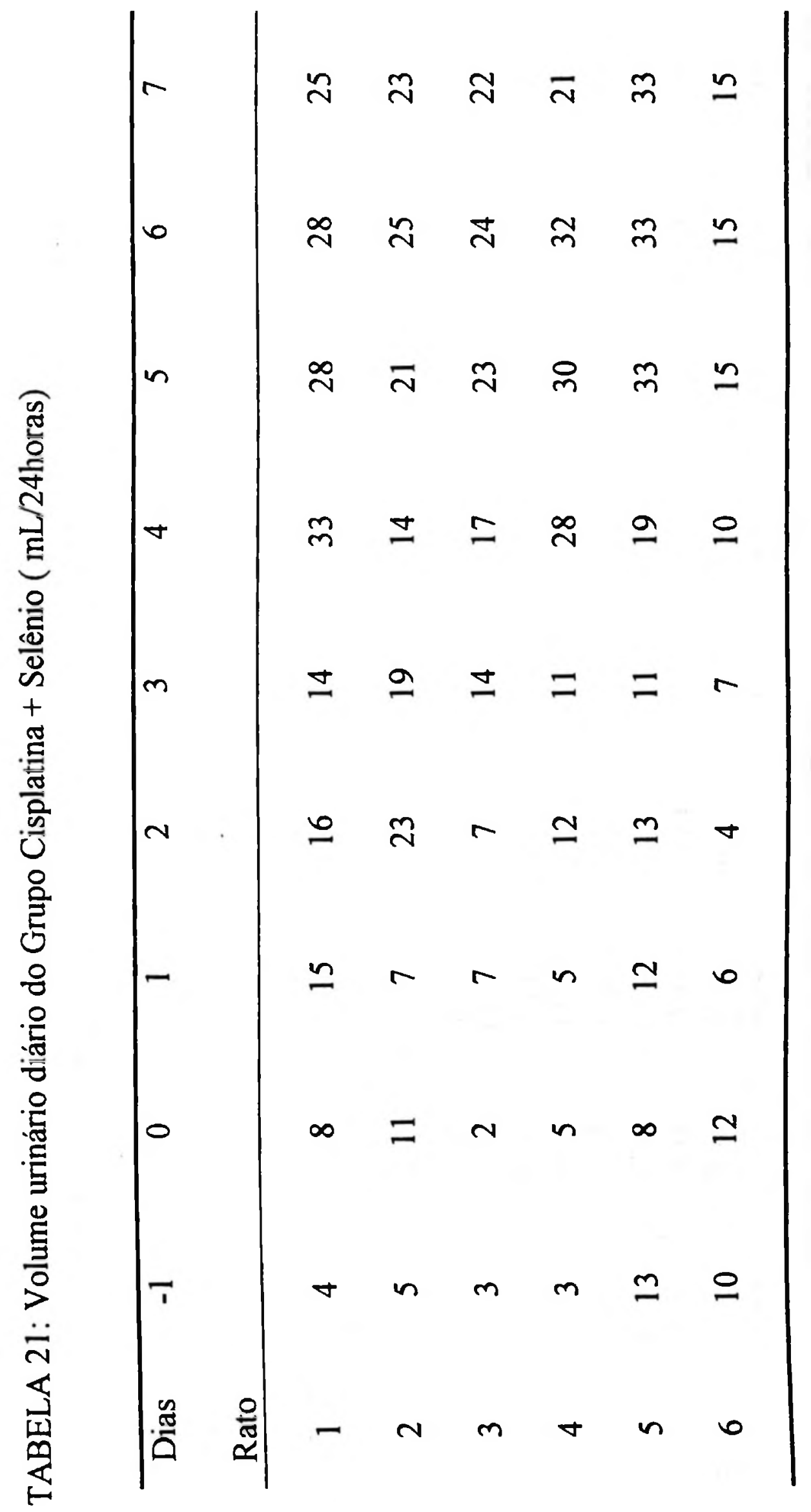




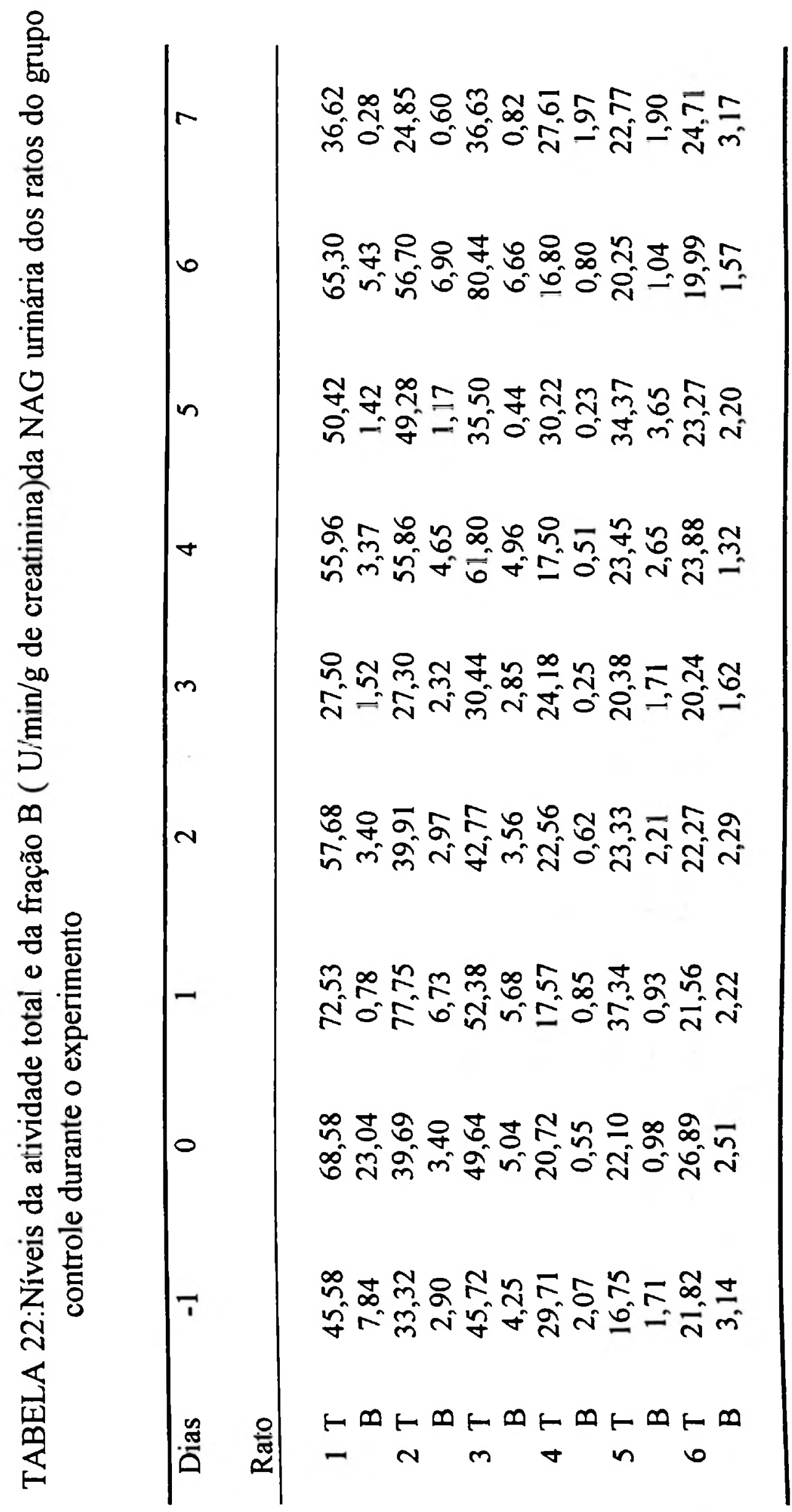




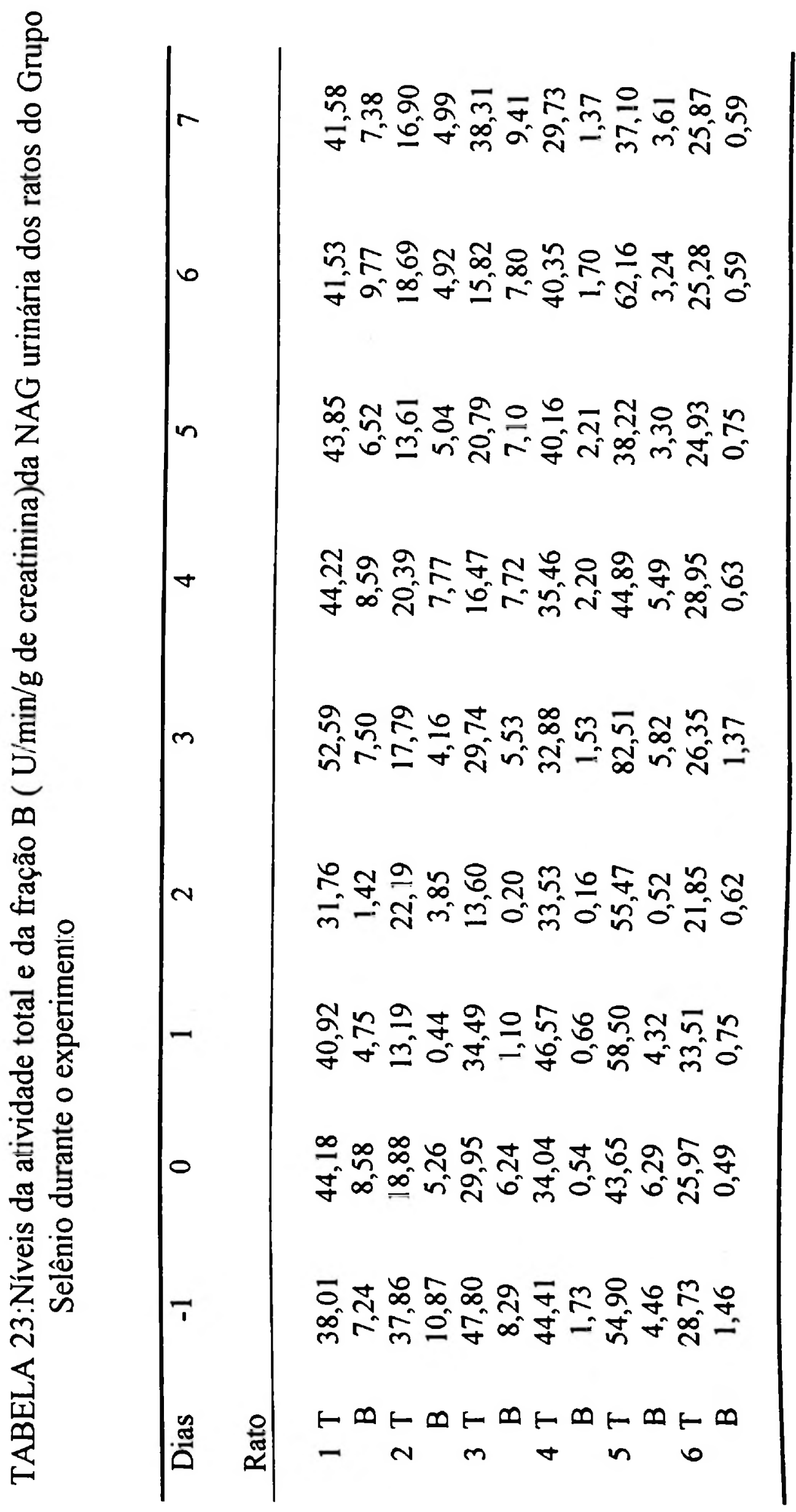




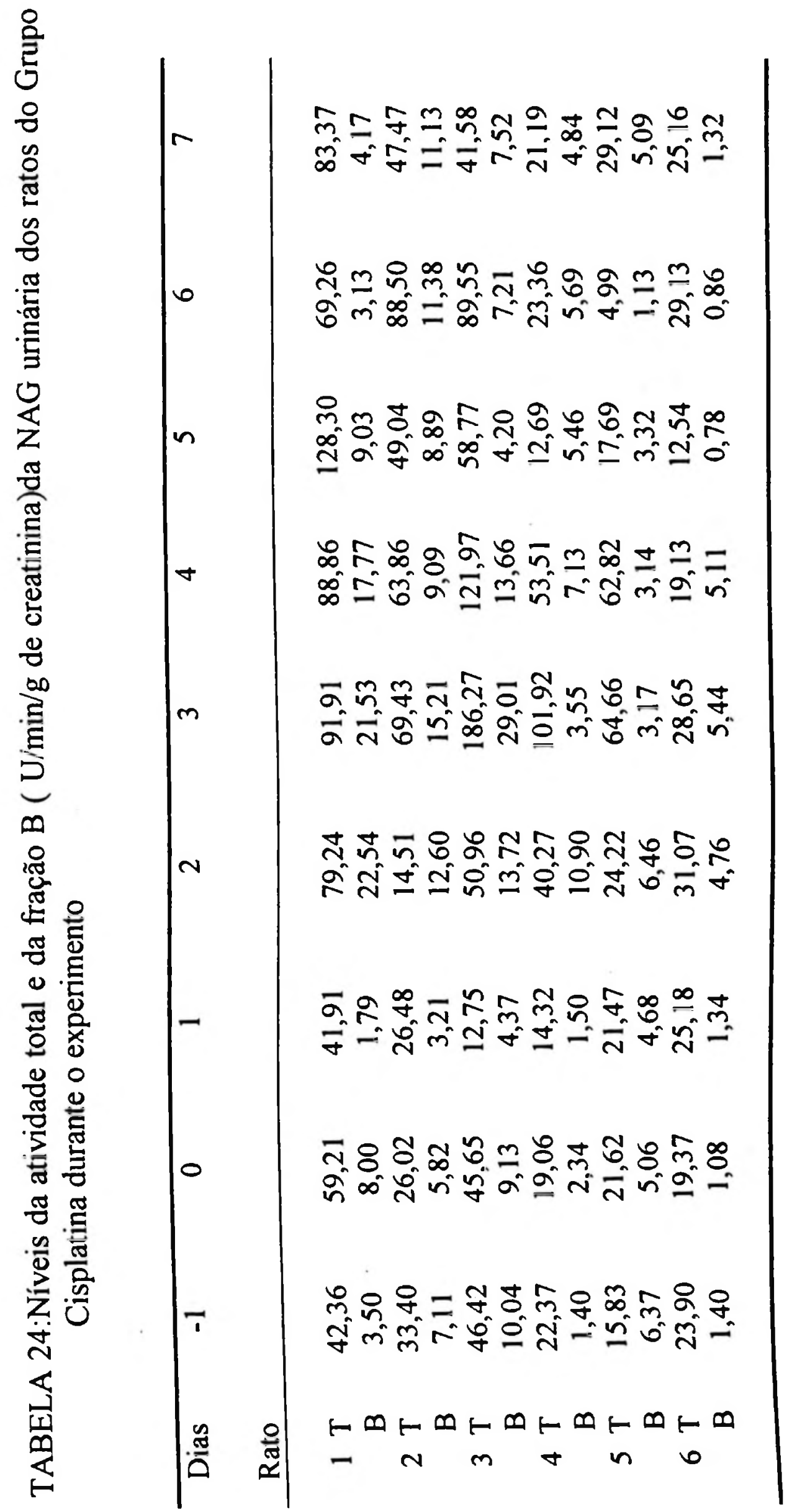




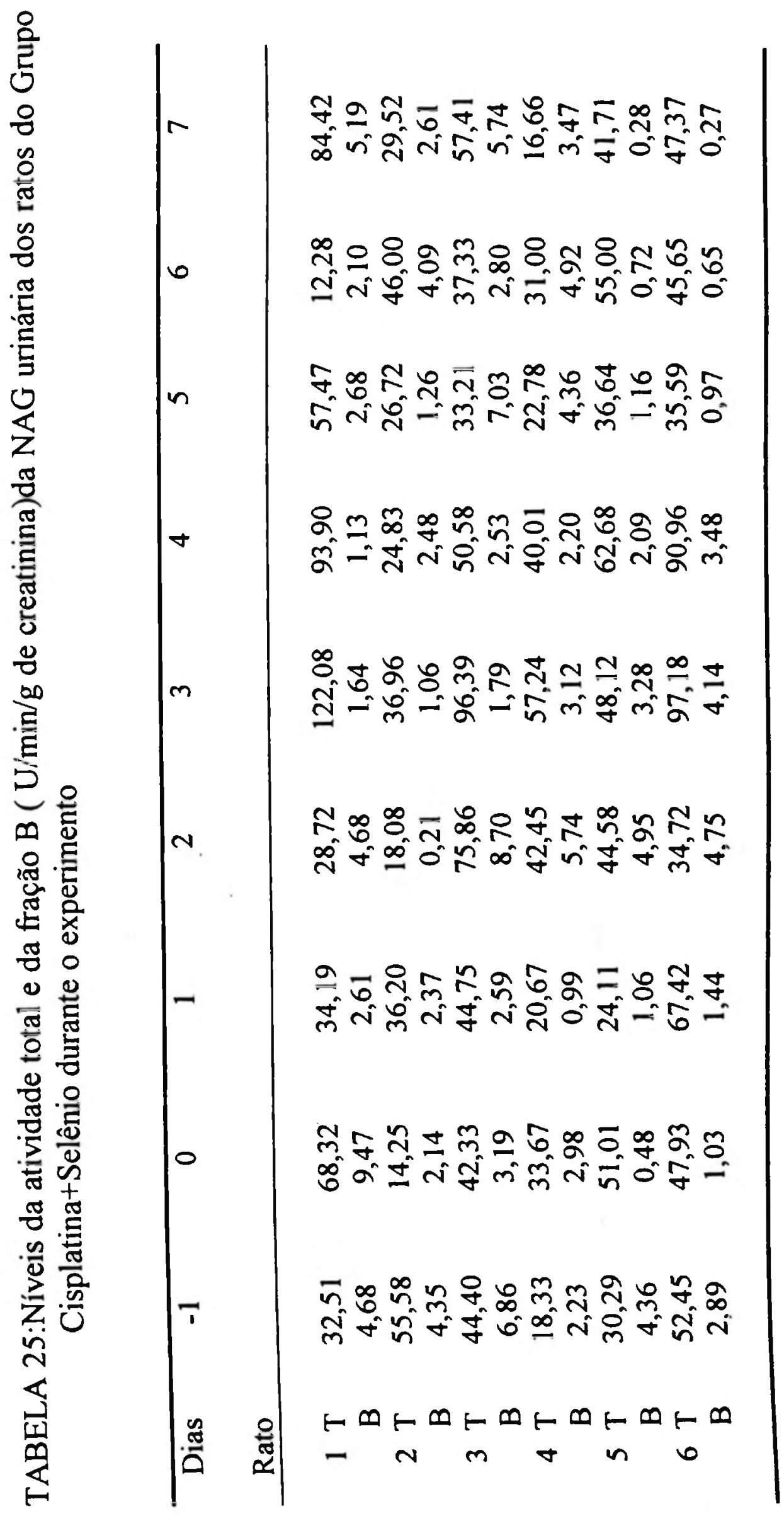




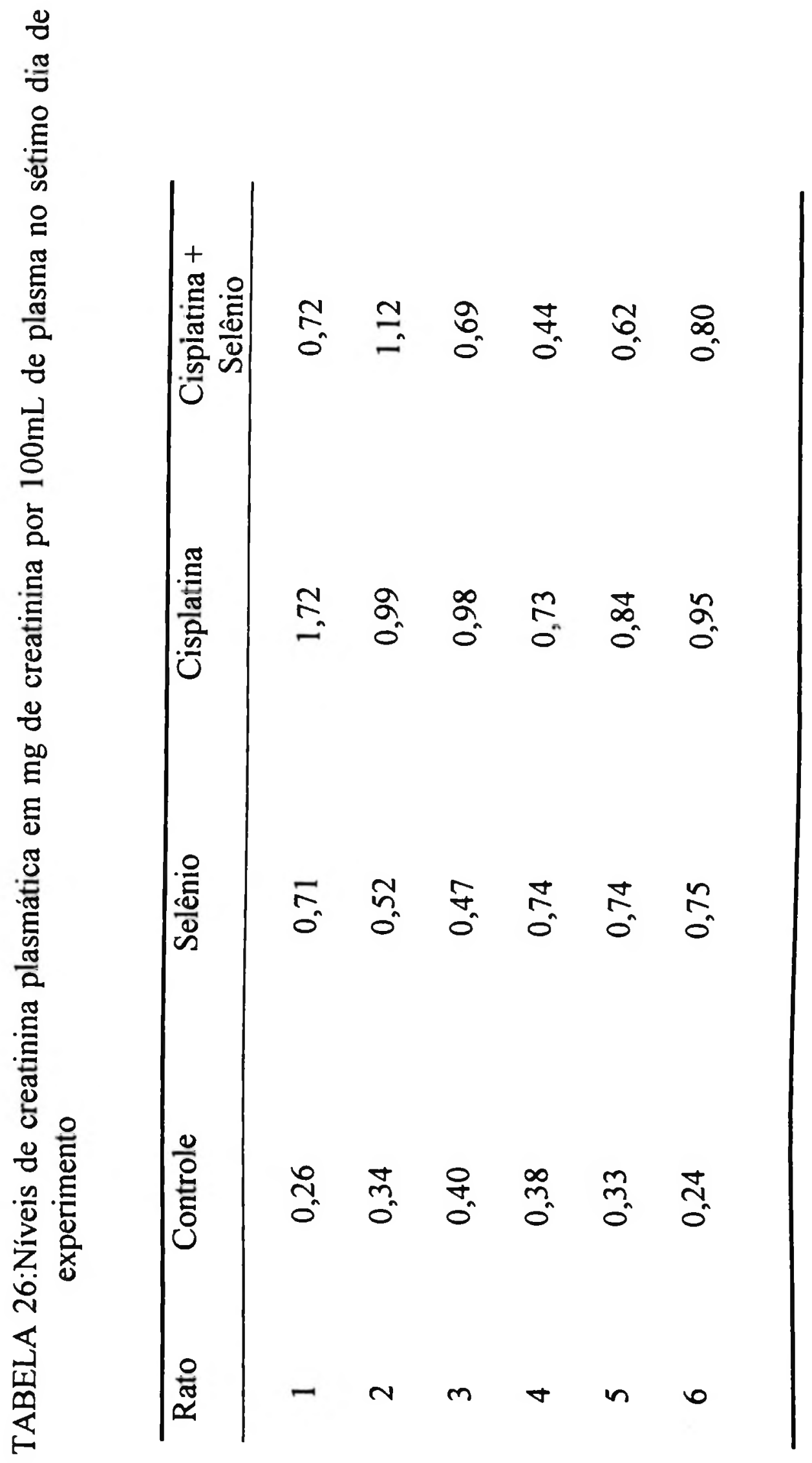




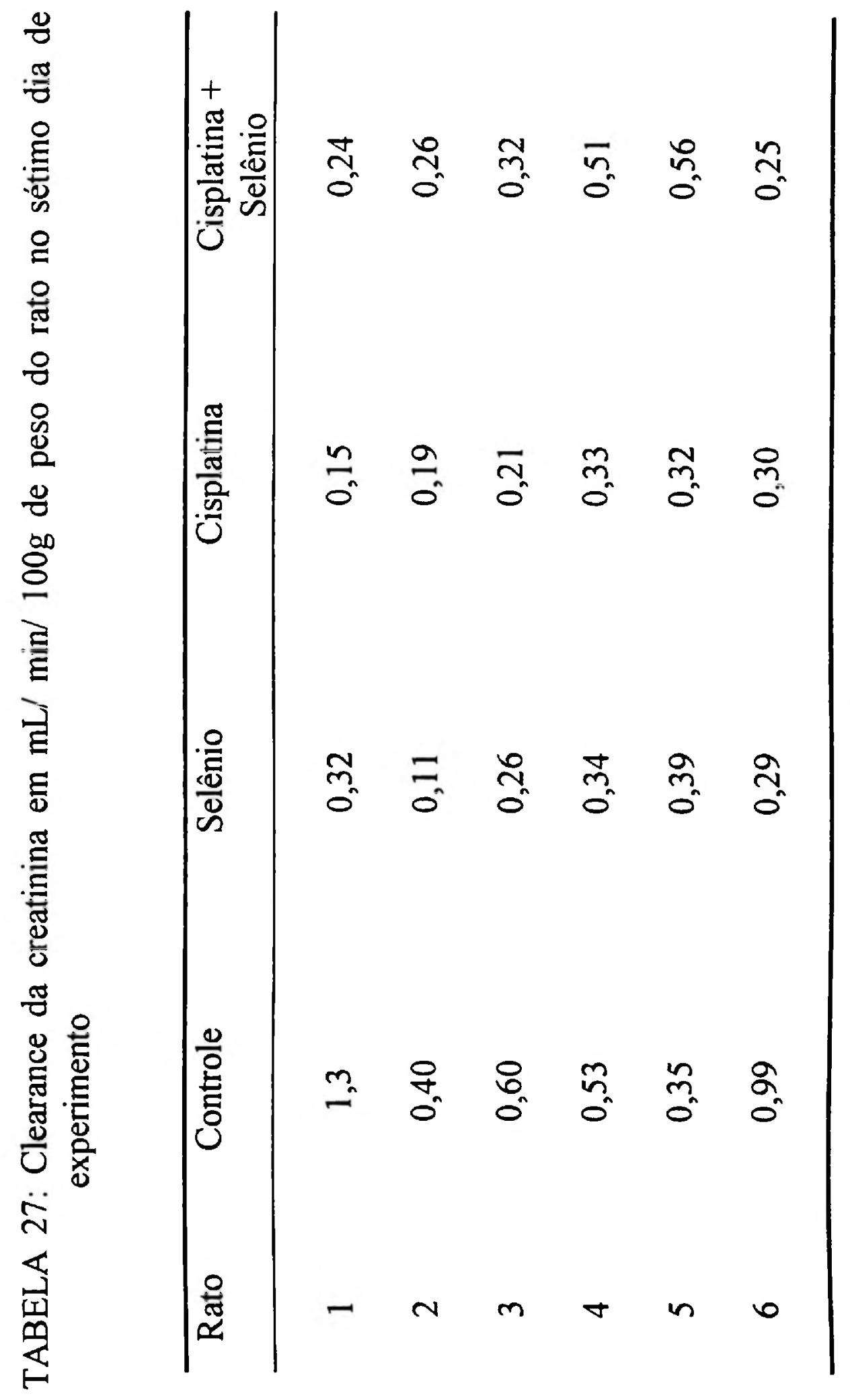




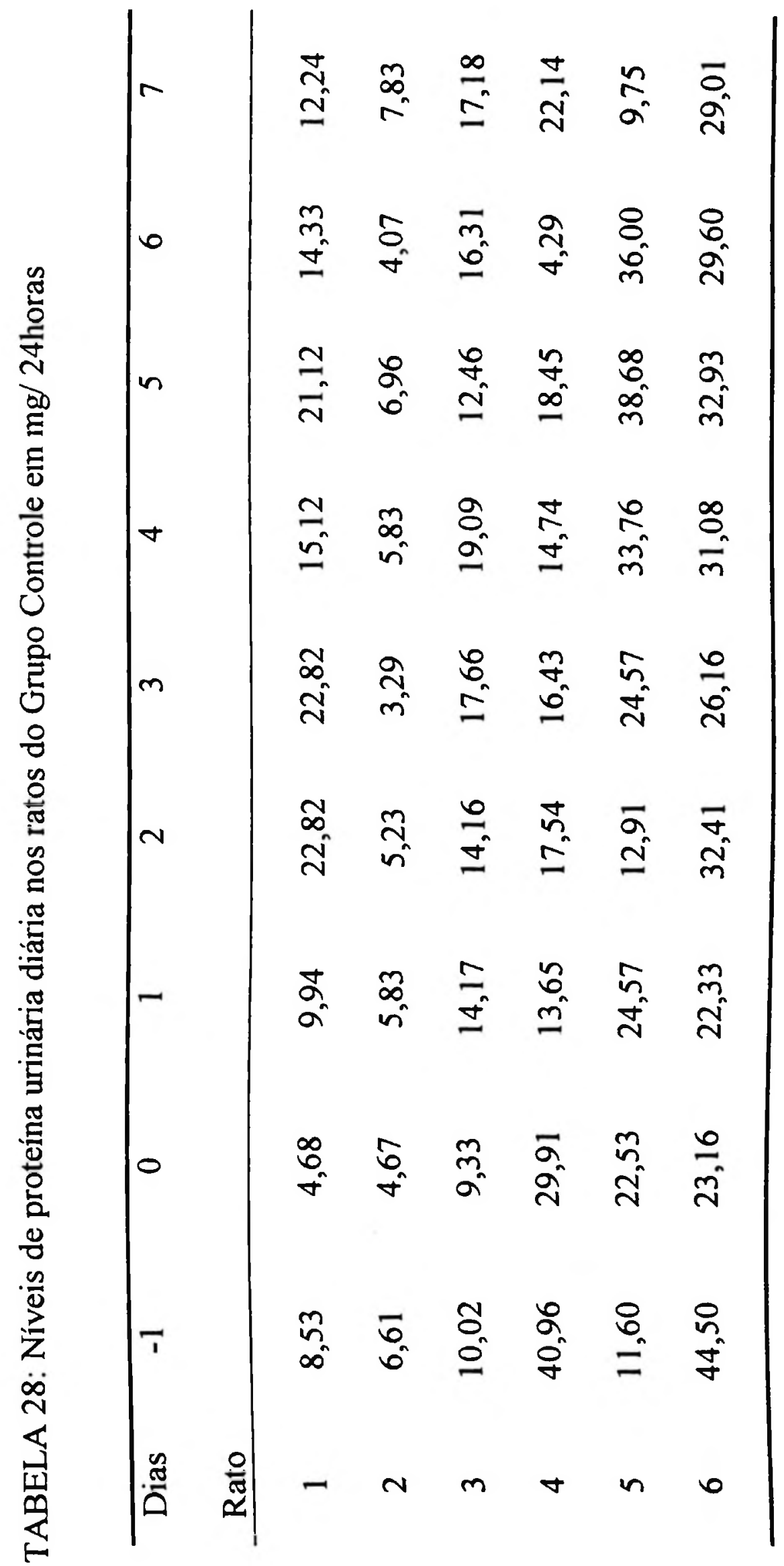




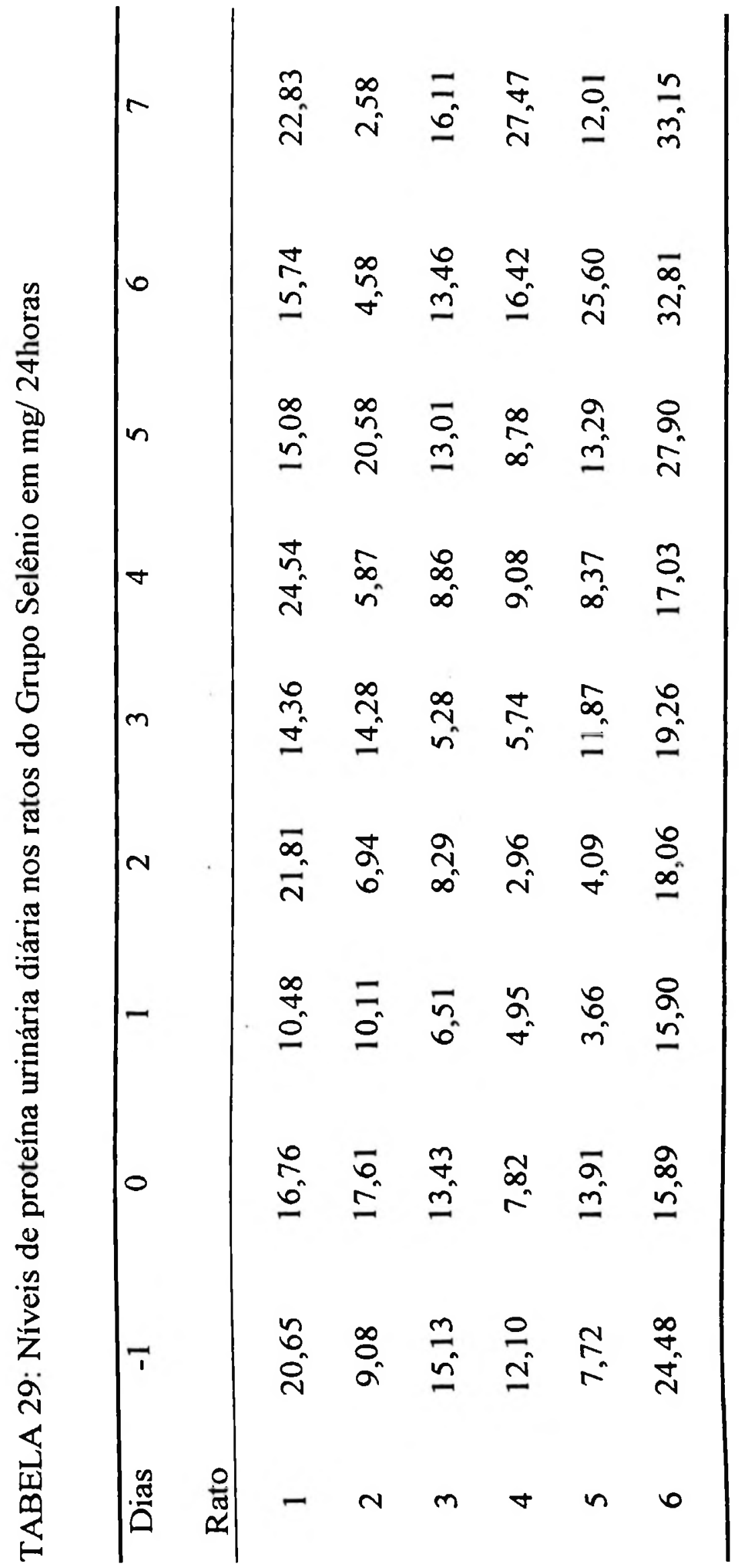




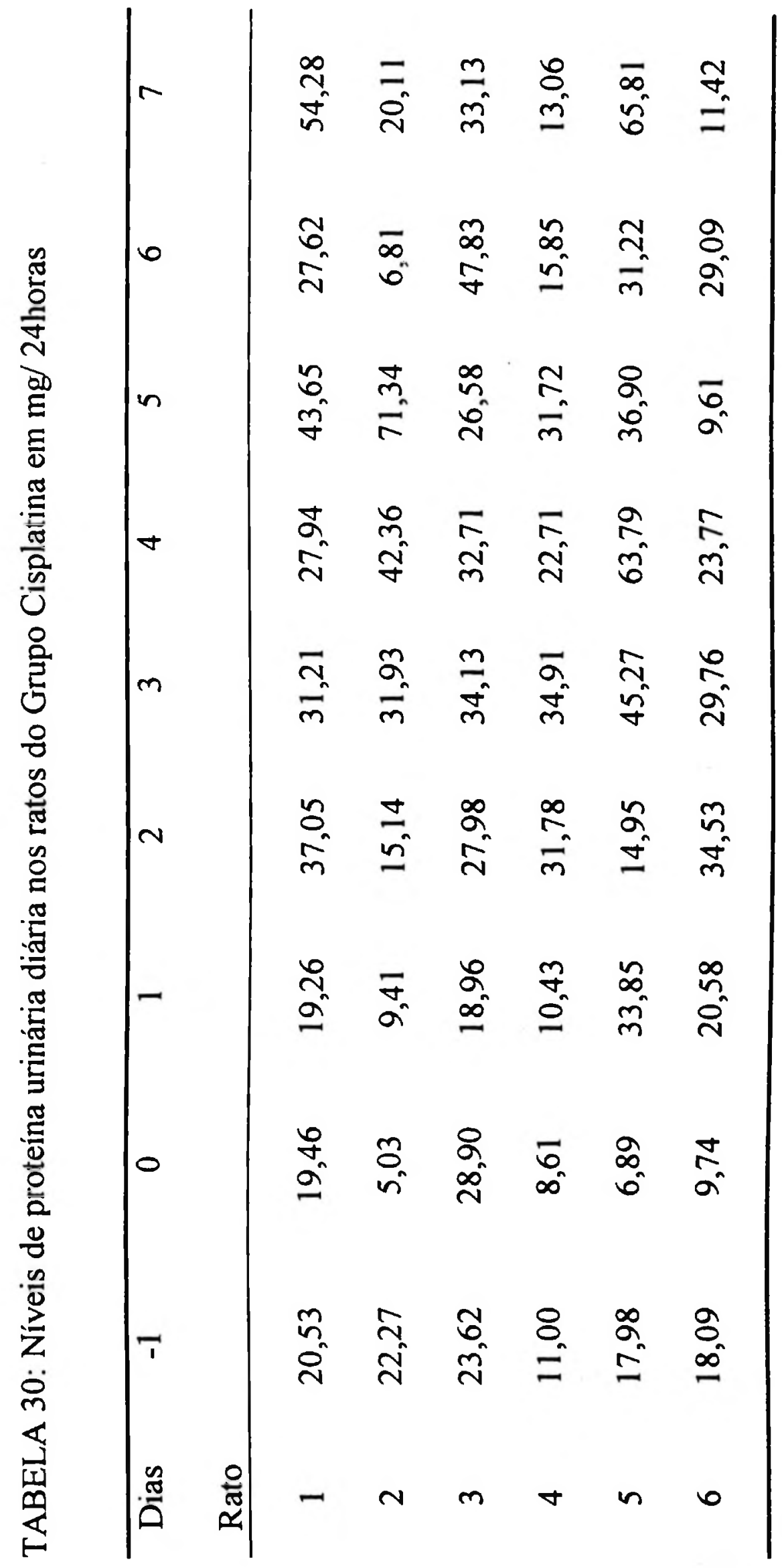




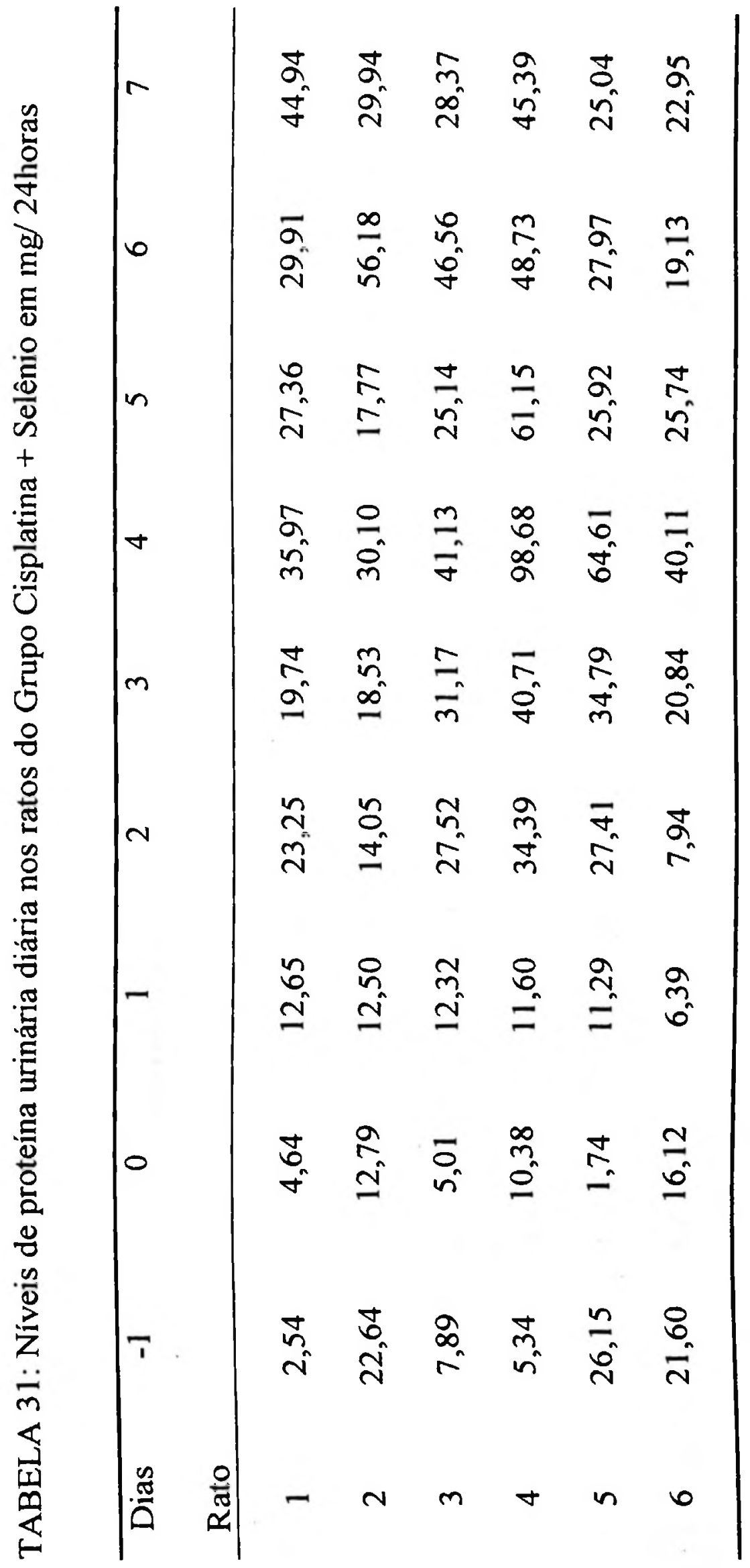




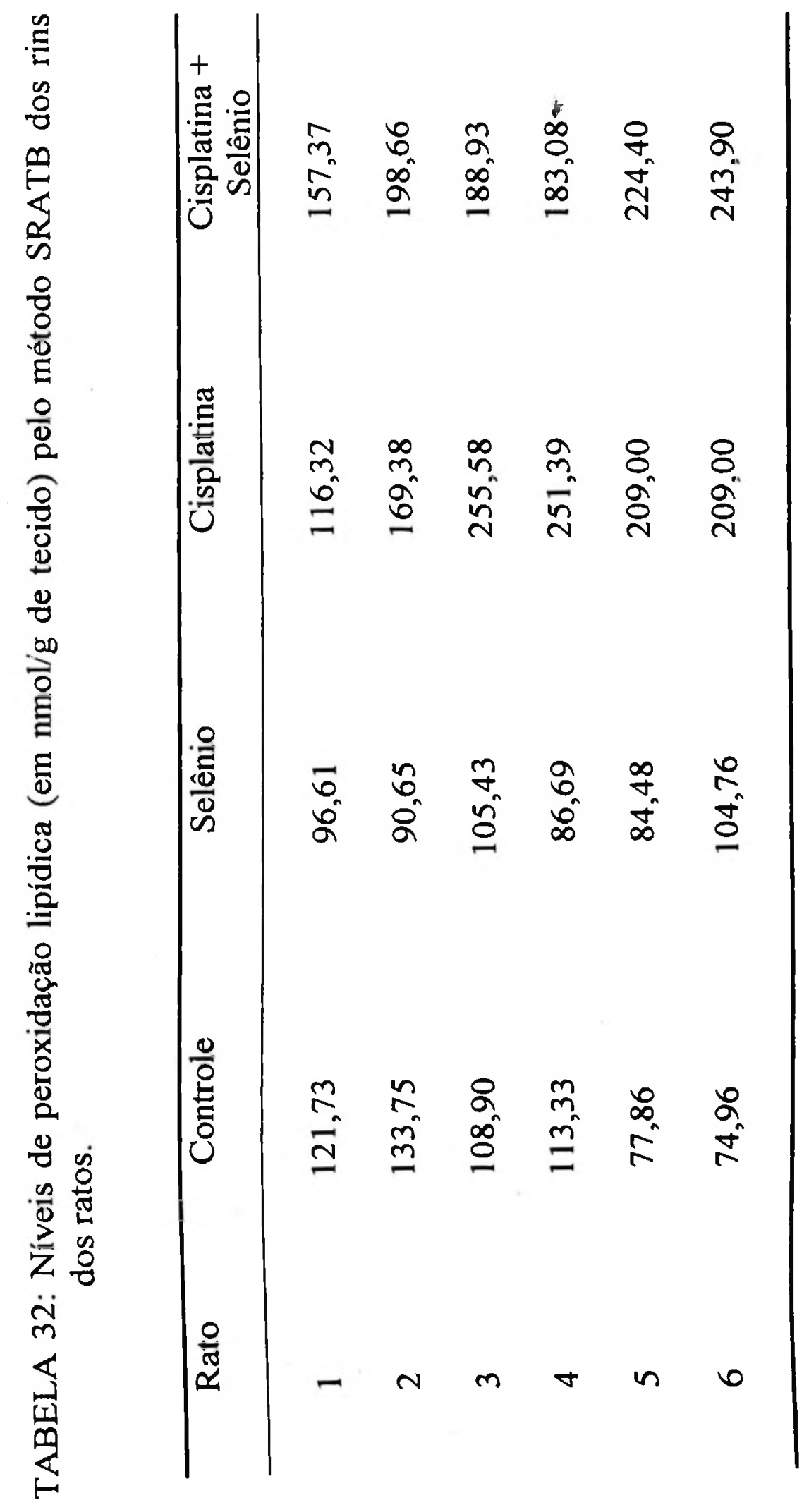




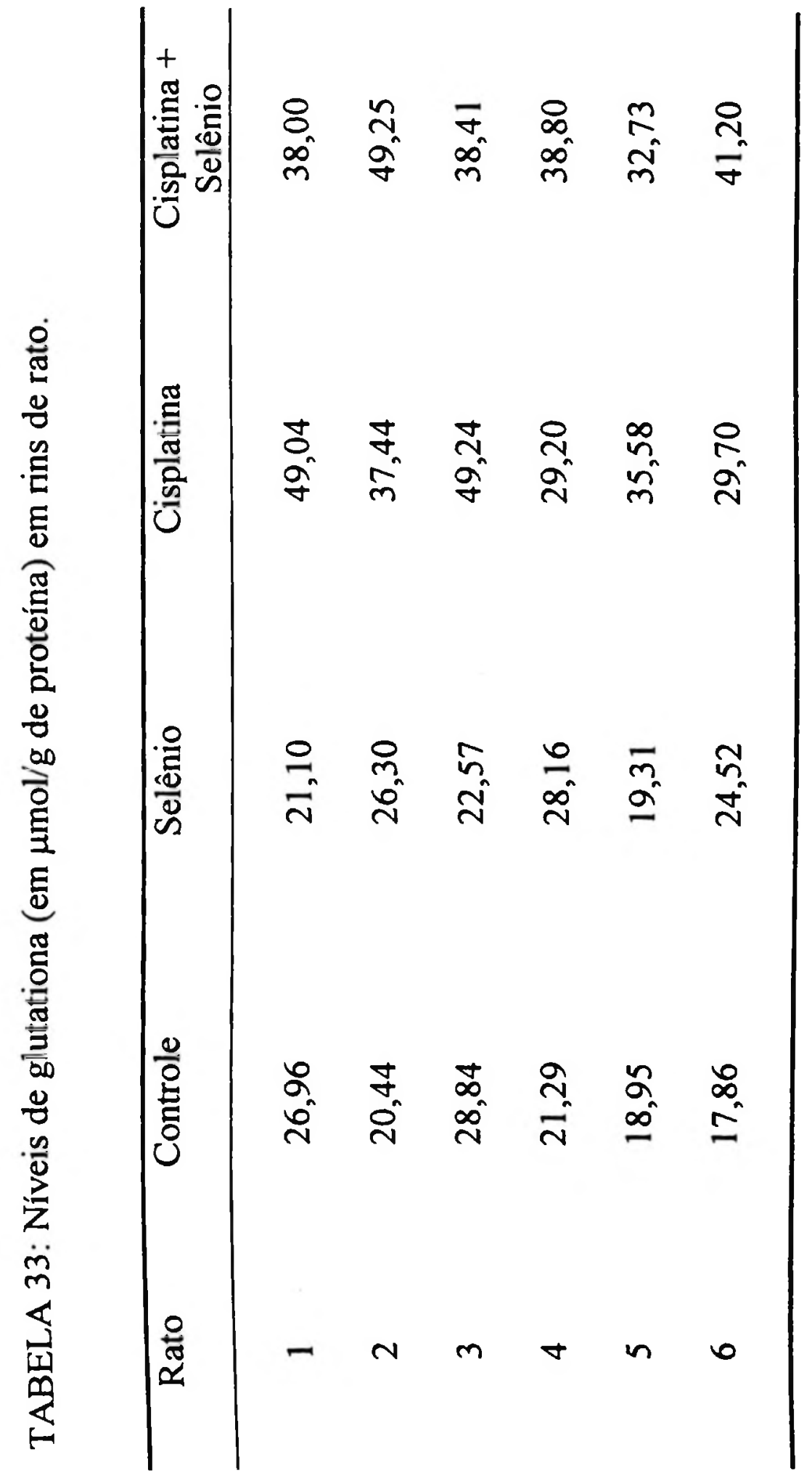

